Portland State University

PDXScholar

$1-1-2010$

\title{
Effects of Biochar-Amended Soil on the Water Quality of Greenroof Runoff
}

Deborah Aileen Beck

Portland State University

Follow this and additional works at: https://pdxscholar.library.pdx.edu/open_access_etds Let us know how access to this document benefits you.

\section{Recommended Citation}

Beck, Deborah Aileen, "Effects of Biochar-Amended Soil on the Water Quality of Greenroof Runoff" (2010). Dissertations and Theses. Paper 47.

https://doi.org/10.15760/etd.47

This Thesis is brought to you for free and open access. It has been accepted for inclusion in Dissertations and Theses by an authorized administrator of PDXScholar. Please contact us if we can make this document more accessible: pdxscholar@pdx.edu. 
Effects of Biochar-Amended Soil on the Water Quality of Greenroof Runoff

by

Deborah Aileen Beck

A thesis submitted in partial fulfillment of the requirements for the degree of

Master of Science

in

Civil and Environmental Engineering

Thesis Committee:

Gwynn R. Johnson, Chair

Graig Spolek

Christopher John Berger

Portland State University

(C)2010 


\begin{abstract}
As the numbers of installed greenroofs continue to grow internationally, designing greenroof growing media to reduce the amount of nutrients in the stormwater runoff is becoming essential. Biochar, a carbon-net-negative soil amendment, has been promoted for its ability to retain nutrients in soils and increase soil fertility. This study evaluated the effect on water quality of greenroof runoff after adding biochar to a typical extensive greenroof soil. Prototype greenroof trays with and without $7 \%$ biochar (by weight) were planted with sedum or ryegrass, with barren soil trays for controls. The greenroof trays were subjected to two sequential $2.9 \mathrm{in} / \mathrm{hr}$ rainfall events using a rainfall simulator. Runoff from the rainfall events was collected and evaluated for total nitrogen, total phosphorus, nitrate, phosphate, total organic carbon, and inorganic carbon. Greenroof trays containing biochar showed lower quantities of nutrients in the stormwater runoff compared to trays without biochar. Biochar-amended soil with and without plants showed a 3- to 25-fold decrease in release of nitrate and total nitrogen concentrations, as well as a decrease in phosphate and total phosphorus concentrations release into the rainfall runoff. Phosphorus results from trays planted with sedum indicate that sedum interacted with both soils to cause a decrease of phosphorus in the greenroof runoff. In correlation with a visual effect in turbidity, biochar-amended soil showed a reduction of total organic carbon in the runoff by a factor of 3 to 4 for all soil and plant trays. Inorganic carbon was similar for all tests showing that inorganic carbon neither reacted with, nor was retained by,
\end{abstract}


biochar in the soil. The addition of biochar to greenroof soil is an effective way to retain nutrients in a greenroof soil, reduce future fertilizer demands, and improve the water quality of the stormwater runoff by reducing nitrogen, phosphorus, and total organic carbon concentrations in the runoff water. 


\section{ACKNOWLEDGMENTS}

I would like to gratefully acknowledge Dr. Graig Spolek, who opened up his lab to the idea of testing biochar, without his kindness, expertise and ongoing support this study would not have been possible. I also thank my advisor, Dr. Gwynn Johnson, for sharing her time and wisdom, and Dr. Chris Berger who presented an ever-kind presence.

I want to express my gratitude to Dr. David Feinstein for his encouragement, numerous stimulating discussions, help with experimental design, and most precise and accurate advice.

I am grateful to my fellow engineering students, in particular the students of the GBRL lab for their on-going moral support and assistance with a variety of fun and tedious tasks; Eduardo Guerrero, Seth Moody, Zdenek Zumr, Giorgina Castillo, Ziyang Liu, Johnathon Boschiero, Harriet Bell, and Norman Buccola.

Special thanks to International Tech Corporation for donating biochar, ProTime Lawn Seed of Hobbs and Hopkins LTD, for donating ryegrass seed, and to Dave Andrews, owner of Pro-Gro Mixes \& Materials for donating Pro-Gro Extensive mix to this study.

Finally, I am forever indebted to my parents for their understanding, endless patience, and encouragement when it was most required. 
TABLE OF CONTENTS

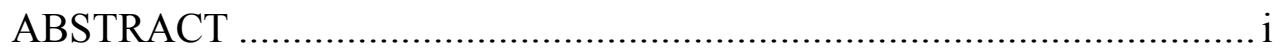

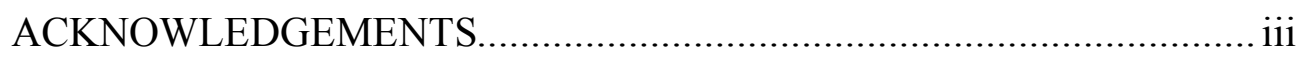

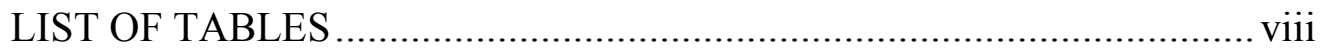

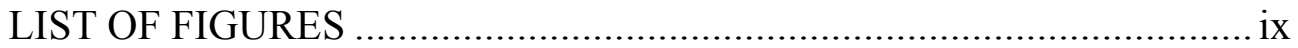

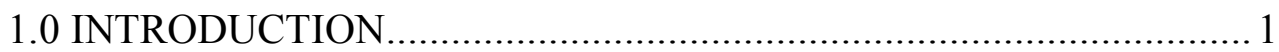

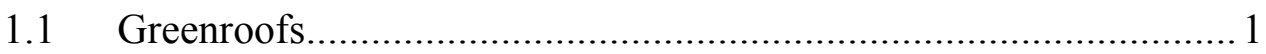

1.2 Water Quality of Runoff from Conventional Roofs......................... 2

1.3 Water Quality of Runoff from Greenroofs …………...................... 2

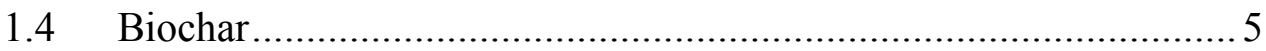

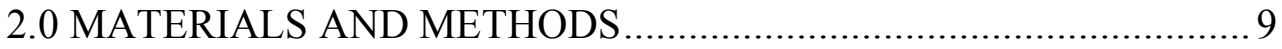

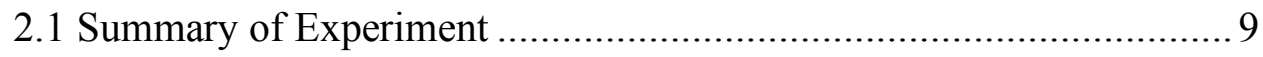

2.2 Overview of the Testing Unit (GERTY) ............................................. 10

Load Cells and Data Acquisition...................................................... 11

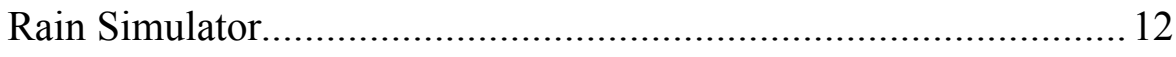

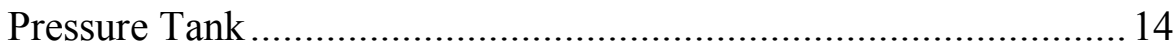

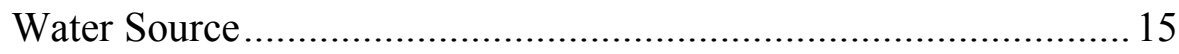

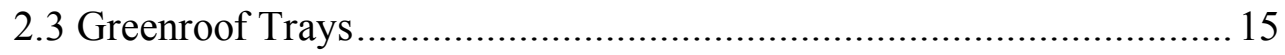

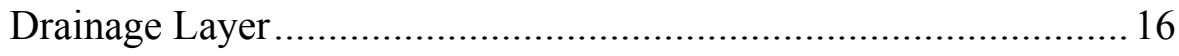

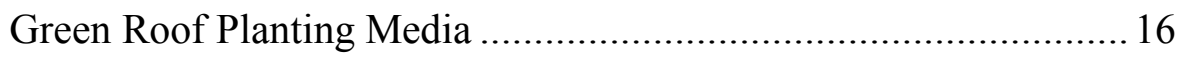


2.4 Biochar

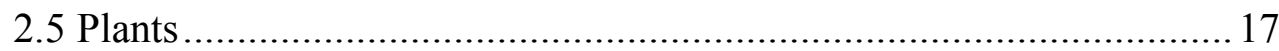

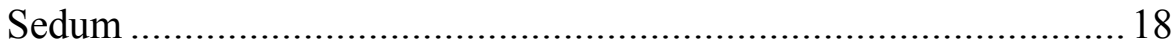

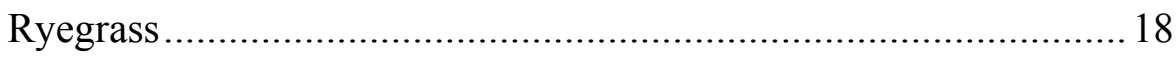

Vinca

2.6 Assembly and Planting of Greenroof Trays .......................................... 19

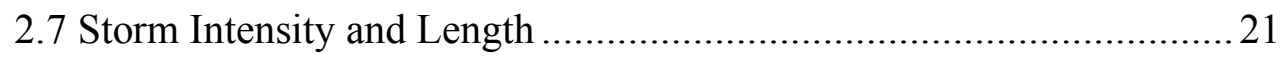

2.8 Final Testing Protocol...................................................................... 22

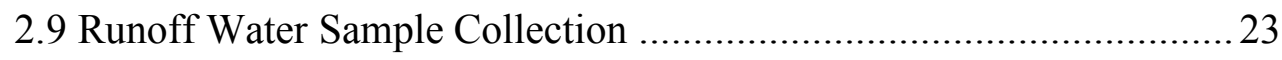

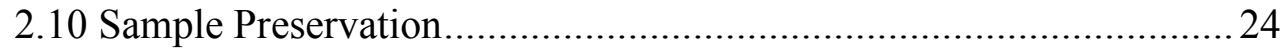

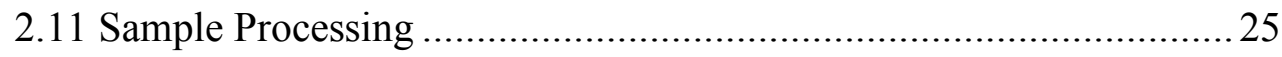

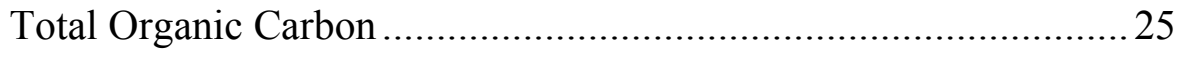

FIA

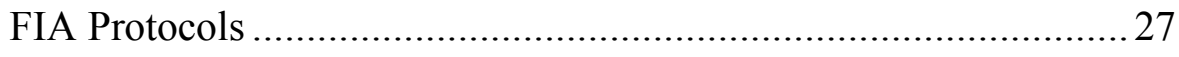

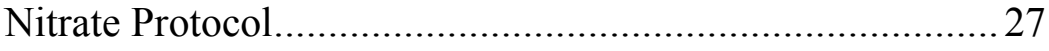

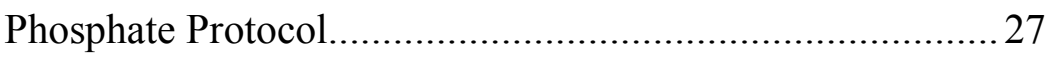

Total Phosphorus and Total Nitrogen Protocol .....................28

2.12 Total Dissolved Solids and Suspended Sediment Concentration.......29

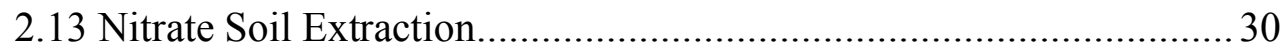

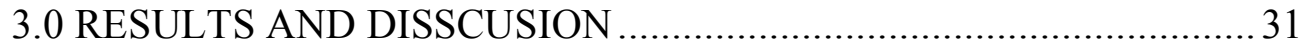

3.1 Pro-Gro Soil versus Biochar-Amended Soil for All Trays .....................31

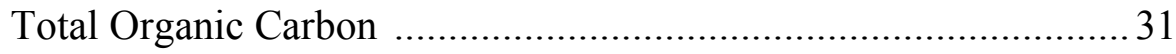

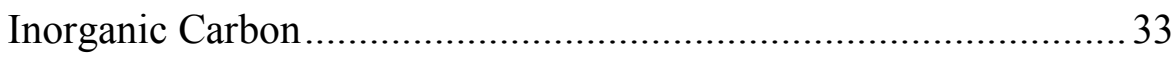




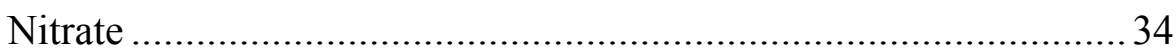

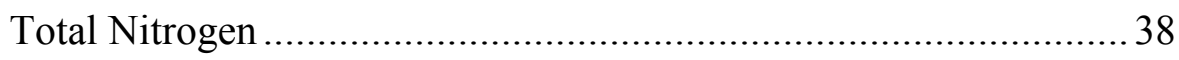

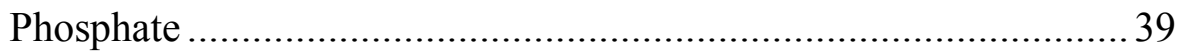

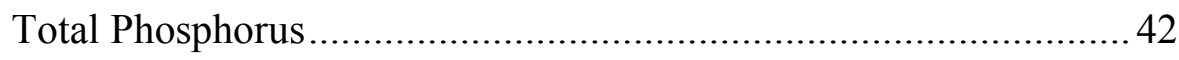

3.2 Rainfall Rates, Rainfall Runoff Rates and Collected Volume Error ... 44

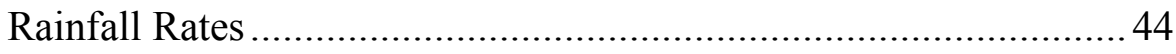

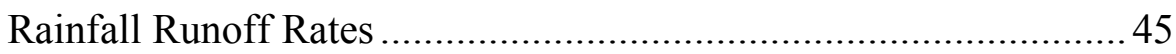

Collected Volume Error.................................................................... 47

3.3 Run A Unsaturated versus Run B Saturated........................................ 48

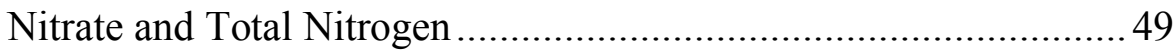

Phosphate and Total Phosphorus.....................................................52

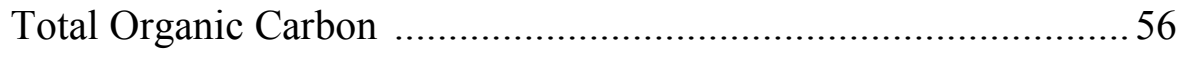

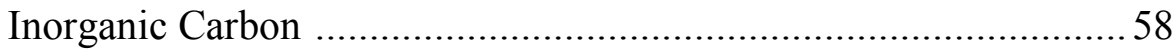

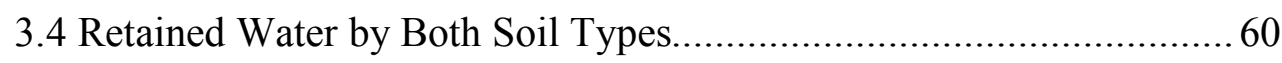

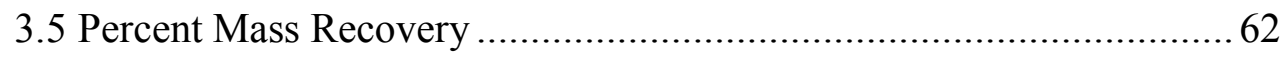

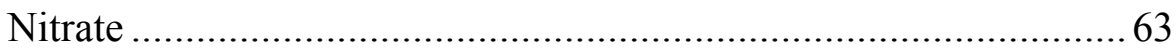

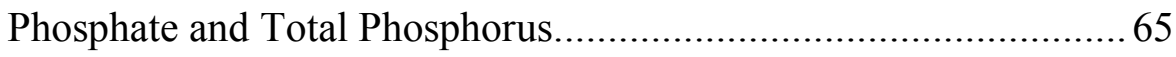

Total Organic Carbon and Inorganic Carbon …………..................... 68

3.6 Total Mass Released into Rainfall Runoff ............................................ 71

Nitrate and Phosphate ................................................................... 71

Total Organic Carbon and Inorganic Carbon..................................... 73

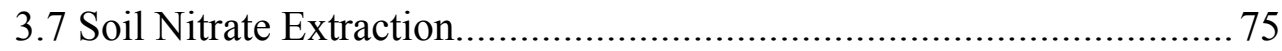

3.8 Total Dissolved Sentiment and Suspended Sediment Concentrations.. 77 


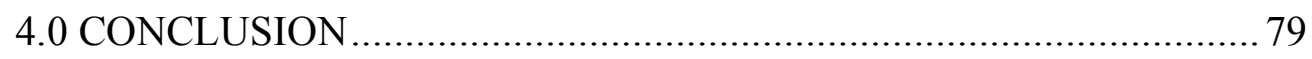

WORKS CITED ........................................................................ 81

\section{APPENDICES}

A Phosphate and Nitrate FIA Programs ......................................... 85

B Total Phosphorous and Total Nitrogen Simultaneous Digestion......88

C FIA Uncertainty Analysis for Phosphate and Nitrate.................... 89

D Acid Preservation on Total Phosphorus and Total Nitrogen ............ 92

E Total Carbon Sample Results.................................................. 98

F Nitrogen and Phosphorus Sample Results ................................ 102 


\section{LIST OF TABLES}

Table 1. Quantities of biochar added to soil for a variety of studies.... 17

Table 2. Tray labels for the different soil and plant types ................. 20

Table 3. Rainfall rates by run and by tray................................ 44

Table 4. Differences of rainfall runoff volumes and resulting percent error for all plants and each soil type................................ 48

Table 5. Weight of retained water by Pro-Gro soil and biocharamended trays during controlled rainfall events ................. 61

Table 6. Percent Mass of Nutrient Recovered ..................................... 62

Table 7. Total Recovered Mass of Measured Nutrients from Rainfall Runoff ............................................................ 71

Table 8. Results of Nitrate Soil Extraction .................................. 77

Table 9. Total Dissolved Solids (TDS) and Suspended Solids (SS) .... 78 


\section{LIST OF FIGURES}

Figure 1. Green Roof Test and Design Unit (GERTY) .................... 11

Figure 2. Close-up of rainfall simulator.................................... 12

Figure 3. Simulated rainfall as collected by tray verses pressure........ 13

Figure 4. Rainfall verses set pressure using the 0.043 in orifice......... 14

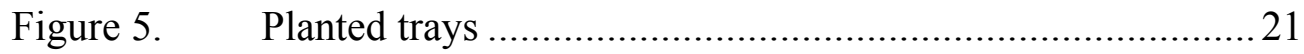

Figure 6. Experiment setup in GERTY..................................... 24

Figure 7. Cumulative distribution graph of organic carbon............... 32

Figure 8. Rainfall runoff samples from soil-only trays.....................33

Figure 9. Cumulative distribution graph of inorganic carbon............. 34

Figure 10. Cumulative distribution graph of nitrate .......................... 36

Figure 11. Breakdown of fractions of nitrate samples....................... 37

Figure 12. Cumulative distribution graph total nitrogen ....................39

Figure 13. Cumulative distribution graph of phosphate .................... 40

Figure 14. Breakdown of fractions of phosphate .............................. 41

Figure 15. Cumulative distribution graph of total phosphorus ............43

Figure 16. Average rainfall rates onto trays by run with error bars ....... 45

Figure 17. Rainfall runoff rates for each liter of collected runoff......... 46

Figure 18. Final representative curve of rainfall runoff...................... 47

Figure 19. Representative rainfall runoff curve with error bars ...........47

Figure 20. Nitrate concentrations of rainfall runoff...........................51

Figure 21. Phosphate concentrations of rainfall runoff ......................55

Figure 22. Total phosphorus concentrations ................................ 55 
Figure 23. Total organic carbon concentrations of rainfall runoff ........57

Figure 24. Inorganic carbon concentrations in rainfall runoff ..............59

Figure 25. Percent mass recovery of nitrate...................................... 64

Figure 26. Percent mass recovery of phosphate ................................ 66

Figure 27. Percent mass recovery of total phosphorus ......................6 67

Figure 28. Percent mass recovery of total organic carbon.................. 69

Figure 29. Percent mass recovery of inorganic carbon...................... 70

Figure 30. Total mass of nitrate and total nitrogen released by tray ...... 72

Figure 31. Total mass of phosphate released by tray........................ 73

Figure 32. Mass of total organic carbon released by tray ................... 74

Figure 33. Mass of inorganic carbon released by tray...................... 75 


\subsection{INTRODUCTION}

\subsection{Greenroofs}

Expanding urbanization combined with traditional development practices has resulted in an increase of impervious surfaces nationwide. This in turn has resulted in an increase of surface water runoff and decreased water quality of the runoff. The practice of installing soil and plants on roofs, commonly known as 'Greenroofs' or 'Ecoroofs', instead of hard impervious roof surfaces has been proven to help mitigate these issues. Greenroofs in the United States have been studied for their stormwater retention abilities and their insulation effects. Only recently has the issue of the water quality of the runoff flowing off a greenroof become of interest. Consequently, little research has been done on the water quality of the runoff from a greenroof. As the runoff water from a greenroof passes through a layer of soil, the runoff has the potential to pick up nutrients and heavy metals and carry these constituents to the receiving water bodies or wastewater treatment system. Past studies have shown that unacceptable levels of phosphorous and nitrogen, as well as some increased concentrations of heavy metals, are seen in the runoff from greenroofs (Berghage et al., 2007; Van Seters et al., 2007; Buccola, 2008; Hathaway et al., 2008; Retzlaff et al., 2008). 


\subsection{Water Quality of Runoff from Conventional Roofs}

Typical construction of buildings in the United States usually includes the installation of a hard impervious surface as the final layer of roofing material. Rainwater flowing off conventional roofs has been shown to pick up pollutants from both the roof substrate and from atmospheric deposition and to transport these pollutants off the rooftops (Ammann et al., 2003; Van Metre and Mahler, 2003). Conventional rooftop runoff has been shown to exceed drinking water guidelines (Meera and Ahammed, 2006), and particle-bound contaminants in runoff from conventional roofs are suspected to contribute to sediment toxicity in receiving water bodies (Van Metre and Mahler, 2003). Metal rooftops have been shown to be a source of cadmium and zinc, and asphalt shingles have been shown to be a source of lead in runoff water (Thomas and Greene, 1993; Van Metre and Mahler, 2003). Polyaromatic hydrocarbons have been observed in runoff water from several roofing materials, which may indicate that roofs collect atmospheric deposition that is then transported by the runoff water (Gadd and Kennedy, 2001; Van Metre and Mahler, 2003).

\subsection{Water Quality of Runoff from Greenroofs}

Water quality of runoff from greenroofs has only recently become an issue of interest. This recent interest corresponds to a limited amount of previous research. However, a few studies have shown that the quality of greenroof runoff has a few common trends. For example, the water quality of runoff from greenroofs is typically thought of as being of better quality than stormwater runoff from conventional roofs. 
Notable exceptions are water-soluble nutrients and metals attached to soil particles that the water has taken up as it travels through the greenroof soil matrix. A Canadian study comparing a large greenroof to an adjoining shingled roof showed reduced stormwater contaminants from the greenroof by mass, with the exception of calcium, magnesium, and total phosphorus, where phosphorus was the only contaminant to pose a threat to receiving waters (Van Seters et al., 2007). Another study compared runoff water quality of two rolled asphalt roofs to three greenroofs of equal size. The results showed concentrations of phosphorous, potassium, calcium, and magnesium in runoff from the greenroofs was higher than from the non-vegetated flat roofs (Berghage et al., 2007). One study of 66 greenroof models observed elevated levels of nitrate from greenroofs compared to 4 conventional roofs (Retzlaff et al., 2008). Buccola (2008) observed greenroof runoff to contain increased levels of phosphorus, nitrate, and total suspended solids compared to the source water used to create the runoff. Greenroof runoff has been observed to have a yellow or tea color compared to the source water creating the runoff. This yellow or tea color is suspected to be a result of humic acids in the runoff (Bergahage et al., 2007; Buccola, 2008).

The makeup of the soil used in the construction of greenroofs is assumed to be the main cause of lower water quality in the runoff (Hunt et al., 2006; Berghage et al., 2008; Teemusk and Mander, 2007; Van Seters et al., 2007; Retzlaff et al., 2008). Two main nutrients of concern observed in greenroof runoff water are phosphorus and nitrogen. When excess nitrogen and phosphorus are present in receiving water bodies, the water bodies can become rich in nutrients, or eutrophic. The more eutrophic a water body is, the more frequently objectionable algae blooms will occur (Droste, 
1997). Phosphate, the biologically available form of phosphorus, is normally the limiting nutrient in fresh waters. Consequently, phosphorus leaching into receiving water bodies is considered one of the main causes of eutrophication of water bodies (Drever, 1997; Lehmann et al., 2005). Nitrogen is sometimes limiting (Drever, 1997). Higher nitrogen and phosphorus concentrations have been repeatedly observed in runoff from greenroofs when compared to control roofs (Van Seters et al., 2007; Hathaway et al., 2008; Retzlaff et al., 2008).

It may be of interest to note that leaching of phosphorus from greenroofs has been observed to decrease significantly after one year suggesting that the nutrient is most likely rapidly leached from the soil and levels would be expected to increasingly drop over time (Van Seters et al., 2007). Another study showed high nitrogen and phosphorus levels with a dramatic reduction in concentration over a few months (Hunt et al., 2006). These observations have led researchers to conclude that the nutrient source deliberately added to greenroof soil matrix, e.g., compost materials and fertilizers, are the main cause of nutrient leaching in the runoff water (Hunt et al., 2006; Teemusk and Mander, 2007; Van Seters et al., 2007; Retzlaff et al., 2008). While this would lead to a demand for decreasing the initial amount of nutrient source matter in a greenroof soil in order to decrease leaching of nutrients (Hunt et al., 2006), a difficulty arises from the necessity of providing plants enough nutrients for growth.

As phosphorus and nitrogen are necessary nutrients for plant growth, there is a need to find a delicate balance between providing sufficient nutrients for healthy plant growth and at the same time reducing leaching of nutrients in the runoff. In responding to this challenge, it has been suggested that soil amendments able to retain nutrients 
would be a welcome addition to the greenroof industry. Van Seters et al. (2007) suggests research is needed to look into soil amendments that render phosphorus insoluble by binding to sediment and then proposes possible use of materials that have shown promise in lake sediments. The desired soil amendment would prevent watersoluble nutrients from leaching into runoff while ensuring these same nutrients remain available to plants on an "as needed" basis. One soil amendment that has been shown to achieve this is called biochar (Glaser et al., 2002; Lehmann et al., 2003; Liang et al., 2006). It is these characteristics of biochar that make it of particular interest as a possible additive to greenroof soils for the purpose of nutrient retention.

\section{$\underline{1.4 \text { Biochar }}$}

Biochar began to attract interest after researchers studying dark colored, fertile, and relic anthropogenic soils in the Amazon found that the soil contained large amounts of pyrogenic carbon (Glaser et al., 2000). The unusually high fertility of these soils is attributed to the presence of this carbon and it is believed that ancient civilizations deliberately tilled in charcoal (biochar) into their fields (Glaser et al., 2000; Steiner et al., 2007). Biochar is made by pyrolysis of biomass in low-oxygen, high-temperature environments (Gaunt and Lehmann, 2008). Australia’s Commonwealth Scientific and Industrial Research Organization, defines biochar as:

Biochar is a fine-grained and porous substance, similar in its appearance to charcoal produced by natural burning. Biochar is produced by the combustion of biomass under oxygen-limited conditions. The definition adopted by the International Biochar Initiative (IBI) furthermore specifies the need for 
purposeful application of the material to soil for agricultural and environmental gain (Sohi et al., 2009).

The success of biochar in ancient soils has prompted several studies to explore biochar's effect on soil fertility. One such study compared biochar to fertilizer and manure when used as soil amendments and showed that the addition of biochar reduced nitrogen leaching (Lehmann et al., 2003). In addition, soil fertility was increased by the addition of biochar as shown by positive effects on crop growth and nutrition. Specifically, biochar additions of $10 \%(\mathrm{w} / \mathrm{w})$ resulted in improved plant growth and a significant increase in biomass production (Lehmann et al., 2003).

Biochar has been observed to retain nitrogen, dissolved organic matter, polar organic pesticides, and hydrophobic components in biochar-amended soils (Glaser et al., 2002). Additionally, biochar has been shown to increase boron, phosphorus, calcium, and molybdenum availability in soils (Rondon et al., 2007). Furthermore, researchers have shown that the addition of biochar to soil increases the soils cation exchange capacity (CEC) (Liang et al., 2006; Cheng et al., 2008). CEC is often used as an indicator of soil fertility and high CEC generally signifies high soil fertility (Sideman, 2006). One study, conducted by Liang et al. (2006) found CEC to be greatest in warmer climate soils receiving biochar additions. When biochar is used as a soil additive, it resists microbial breakdown and is thought to be stable for hundreds of years (Lehmann et al., 2003). It may be of interest to note that biochar's ability to resist microbial breakdown has resulted in biochar being explored as a long-term sink for atmospheric carbon dioxide (Lehmann et al., 2006). 
While the addition of biochar amendments to soils has been clearly demonstrated to facilitate nutrient retention, it is still unclear the physical and/or geochemical mechanisms responsible for this process. Current theories include:

1) Biochar addition to soil results in the creation of sites for electrostatic adsorption (Lehmann et al., 2003).

2) Biochar retains soil porewater and therefore retains the nutrients therein (Lehmann et al., 2003).

3) Biochar affects the microbial community in the soil, including the microbial community composition, species richness, and diversity (Uphoff, 2006; Sohi et al., 2009).

Biochar was chosen for this study for the following reasons:

1) The primary goal of this study was to test retention of phosphorus by biocharamended soil in a greenroof system. In following the sources cited through the biochar literature, all of them appear to be quoting one single source: A study published in 1960, that investigated the chemical abilities of phosphate adsorption by char made from lodgepole pine and duff to three commercially available, activated charcoals. The results showed that the activated charcoals adsorbed more $\mathrm{H}_{2} \mathrm{PO}_{4}{ }^{-}$, than either the lodgepole or duff chars (Beaton et al., 1960).

2) Use of biochar as a soil additive in greenroofs has some attractive advantages over other manufactured soil additives. The method of production of biochar 
results in biochar being a net-negative carbon product. Specifically, the pyrolysis of biomass in a slow, low-oxygen environment causes sequestration of carbon instead of releasing carbon into the atmosphere. In addition to being carbon net-negative, biochar is most often a byproduct of bioenergy production rather than a product itself (Gaunt and Lehmann, 2008). If biochar retains nutrients as claimed, it would be an environmentally friendly soil additive to a growing greenroof industry.

3) Biochar has been observed to retain nutrients in soil and to be most effective when added to soils located in warm climates. The shallow soil and exposed conditions of most greenroofs results in plants growing in almost desert-like conditions. These conditions potentially make biochar an ideal addition to greenroof soil.

The main purpose of this study was to evaluate the effects that the addition of biochar to a greenroof soil would have on nutrient retention. Nutrient retention was evaluated by measuring concentrations of total nitrogen, nitrate, total phosphorus, and phosphate in the rainfall runoff from prototype greenroofs. In addition, total organic carbon and inorganic carbon concentrations were evaluated as another measure of greenroof runoff water quality. 


\subsection{MATERIALS AND METHODS}

\subsection{Summary of Experiment}

To evaluate the ability of biochar to retain nutrients in greenroof soil, prototype greenroofs were assembled and planted in metal trays. Trays were lined with Henry DB-50 greenroof drainage membrane. Soil in the form of Pro-Gro extensive mix or Pro-Gro extensive mix containing 7\% w/w biochar, was added to an initial depth of 6 inches. Trays were planted with vinca, sedum, or ryegrass, or left unplanted as soilonly controls. Two trays of each condition were made to allow for replication of conditions. Each set of matching trays were tested in the Green Roof Test and Design Unit (GERTY). GERTY has an installed rainfall simulator and the ability to take continuous weight measurements during rainfall events. Rainfall events were 30 minutes long at a rate of $2.9 \mathrm{in} / \mathrm{hr}$. Trays with plants were tested after the plants reached maturity. Each matching set of trays were subjected to two sequential rainfall events spaced two hours apart. Water samples of the rainfall runoff that resulted from these rainfall events were collected as each liter of rainfall runoff exited each tray. Collected water samples were evaluated for nitrate, phosphate, total nitrogen, and total phosphorus concentrations on a FIALab 2500 flow injection analyzer. Total organic carbon and inorganic carbon concentrations were determined on a Shimadzu TOC-V CSH analyzer. 
The Green Roof Test and Design lab at Portland State University contains a testing unit (GERTY) designed to meet two purposes. The first is to measure the heat transfer through a greenroof under various conditions, and the second is to simulate rainfall events and collect the resulting water samples. The testing unit contains two full spectrum lights designed to produce $1 / 10$ the energy of natural sunlight (roughly $100 \mathrm{~W} / \mathrm{m}^{2}$ ). The unit has the ability to raise temperature above the greenroof test trays as well as lower temperature underneath the test trays simulating summertime conditions. Humidity is adjustable, as is wind speed. To reduce the number of variables all tests for this study were conducted under ambient room temperature conditions. GERTY was utilized to simulate rainfall and to collect rainfall runoff, as well as to continuously weigh trays during rainfall events (Figure 1).

The test unit holds two greenroof trays at a time and the testbed has an adjustable slope. The slope of the testbed was set so that the trays were approximately level by the time waterproofing of the drain holes was accomplished. Waterproofing of the drain holes had to be performed for each test and was accomplished by sealing the drain hole of the test tray to the drain hole in the test bed with $\mathrm{md}^{\mathrm{TM}}$ cord weatherstrip. 


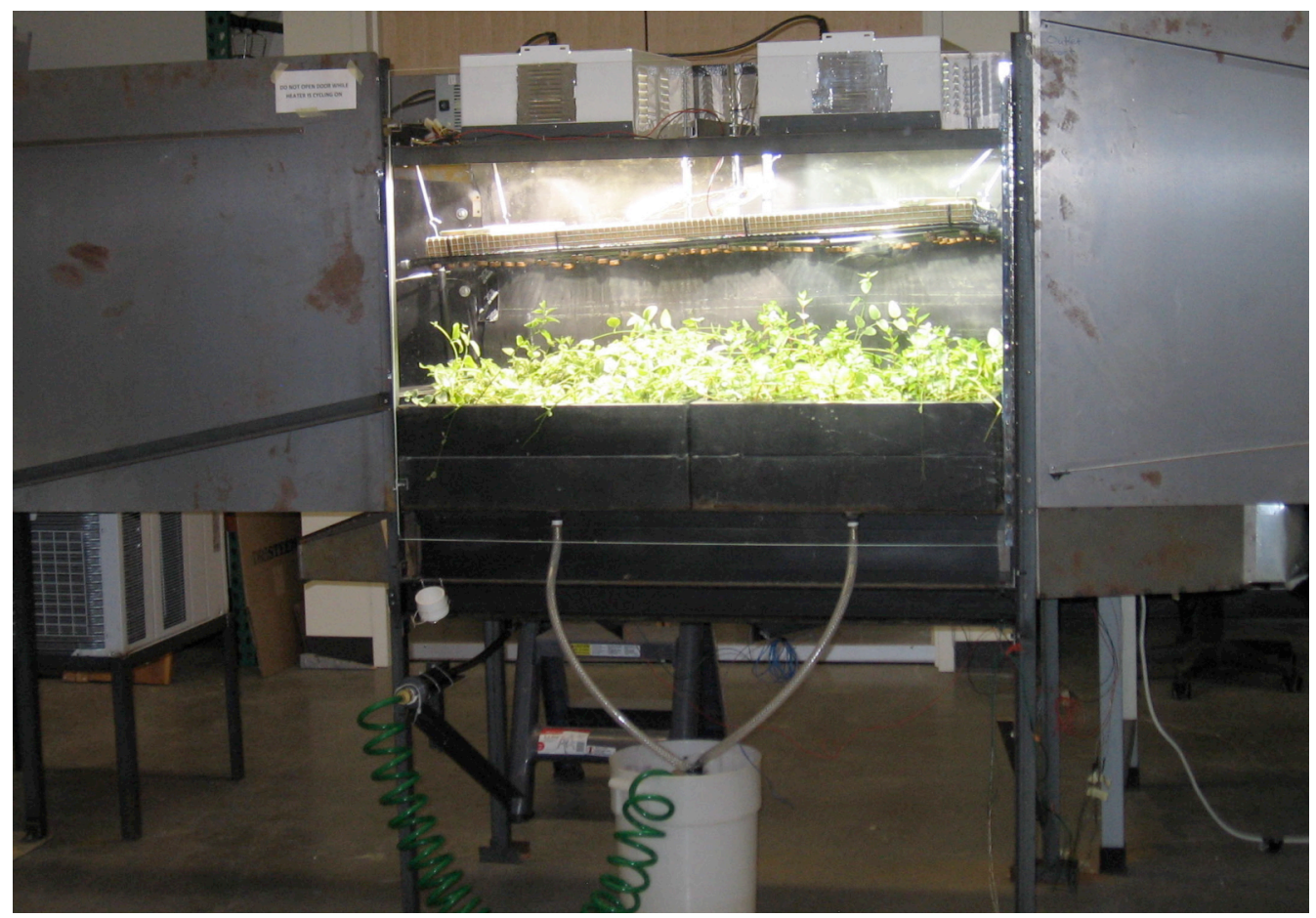

Figure 1: Green Roof Test and Design Unit (GERTY).

\section{$\underline{\text { Load Cells and Data Acquisition }}$}

A single load cell is installed under each of the four corners of the test bed, allowing precise weight measurements to be gathered for the duration of each test. The load cells are (Transducer) Omegadyne Inc. brand, Model LC305-100, and are calibrated to be accurate from 0.00 to $100.00 \mathrm{lbs}$ with an operating temperature range of $60^{\circ} \mathrm{F}$ to $160^{\circ} \mathrm{F}$. Due to the positioning of the load cells, the weight obtained is the total weight of both testing trays combined.

The load cells are wired to a National Instruments Compact DAQ NI cDAQ9172 datalogger that sends the data collected to a Dell Latitute E5400 laptop running LabVIEW SingleExpress Project version 3.0. LabVIEW was set up to collect the 
weight data. The sampling rate is fixed at $1613 \mathrm{~Hz}$ resulting in 16130 samples every 10 seconds.

\section{$\underline{\text { Rainfall Simulator }}$}

The rainfall simulator installed in GERTY consists of drip irrigation nozzles suspended from a wire grid positioned 13" above the top of the trays. The rainfall simulator has 72 nozzles, with 36 nozzles positioned over each tray as seen in Figure 2. The entire grid is suspended from four cords at its corners. An eccentric drive motor moves the water distribution system to deliver uniform rainfall coverage. The simulator results in roughly $80 \%$ equal coverage of water drops over the entire surface area of the trays below, meaning each square inch of soil receives approximately the same amount of water throughout a rainfall event.

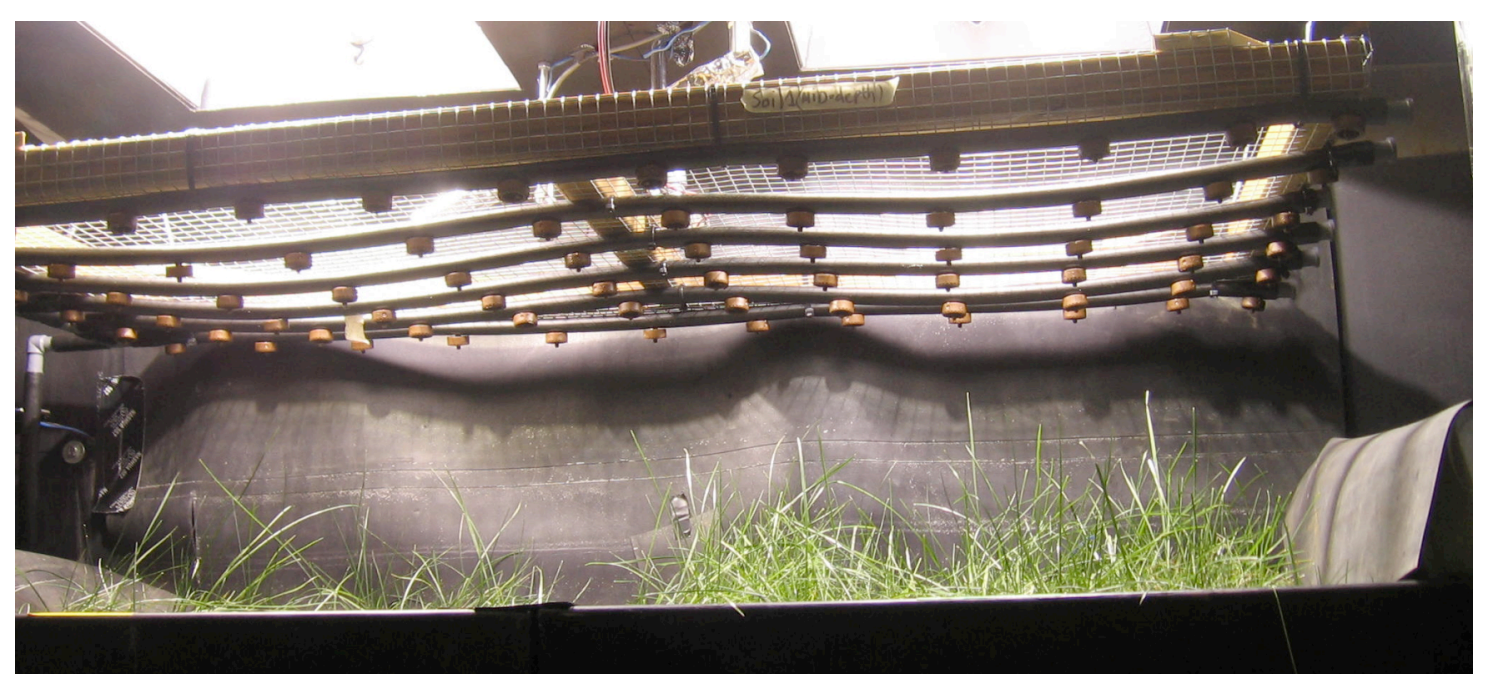

Figure 2: Close-up of rainfall simulator. 
Initial calibrations were done on the rainfall simulator as a whole. Due to differences observed during test runs and to verify consistency of the flow as delivered by the rainfall simulator, the outflow from the rainfall simulator was determined as collected per tray. Figure 3 shows that the left tray consistently receives heavier rainfall than the right tray.

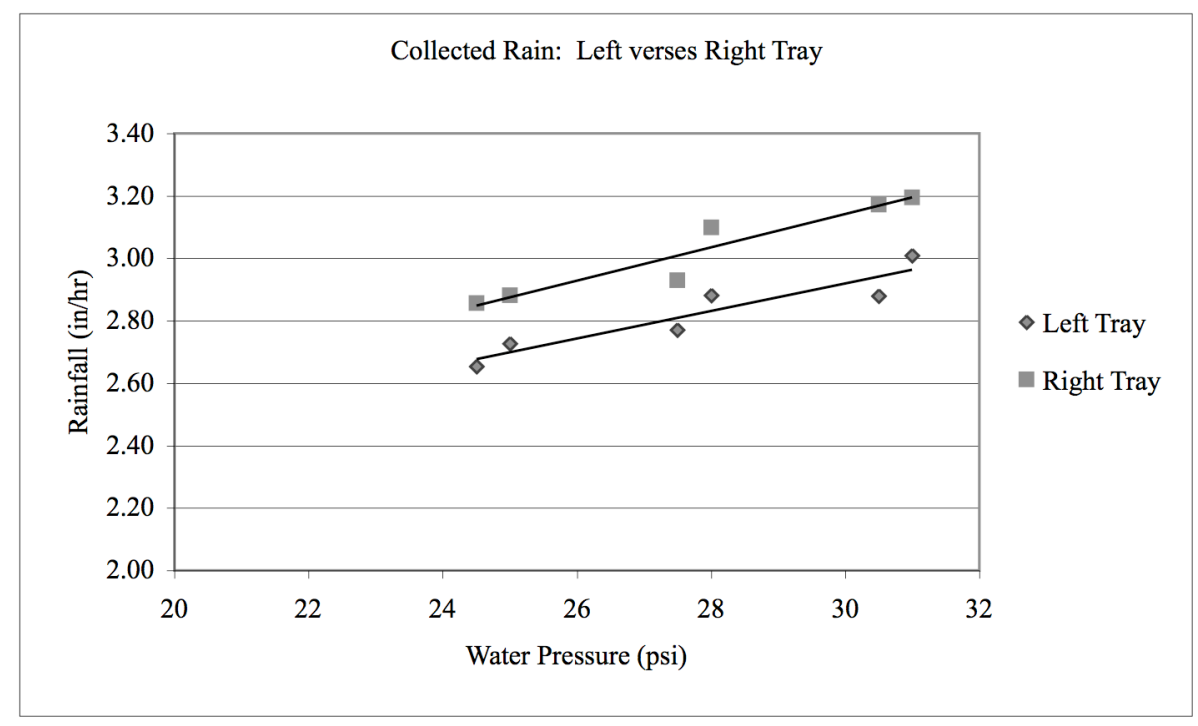

Figure 3: Simulated rainfall (in/hr) as collected by Left or Right Tray verses pressure and corresponding least squares fit lines.

The equations of the lines determined by a least squares fit of the data for the left and right trays were used to calculate the amount of rainfall collected by each tray during each run. The least squares fit for the left tray resulted in the equation $y=0.0534 \mathrm{x}+$ $1.5403, \mathrm{R}^{2}=0.91$, and the least squares fit for the right tray resulted in the equation $\mathrm{y}$ $=0.0441 \mathrm{x}+1.5973, \mathrm{R}^{2}=0.86$, where $\mathrm{x}$ is the running psi and $\mathrm{y}$ is simulated rainfall received by the tray in inches per hour. 
$\underline{\text { Pressure Tank }}$

To allow for maintaining constant water pressure during each test a 10-gallon pressure tank with air agitation made by C. A. Technologies is plumbed to the rainfall simulator. Precisely-sized orifices are inserted between the tank and the receiving hose leading to the rainfall simulator. When combined with the ability to adjust the pressure in the tank the different sized orifices allow for adjustment of flow out of the tank. An existing $0.029 "$ orifice was expanded by drilling to a 0.043 " diameter hole. The 0.043 " orifice size was then calibrated by running the rainfall simulator at a range of pressures and collecting all the water delivered by the rainfall simulator to determine rate of rainfall resulting from different pressure settings on the water tank. Figure 4 shows the relationship of pressure to rainfall is linear.

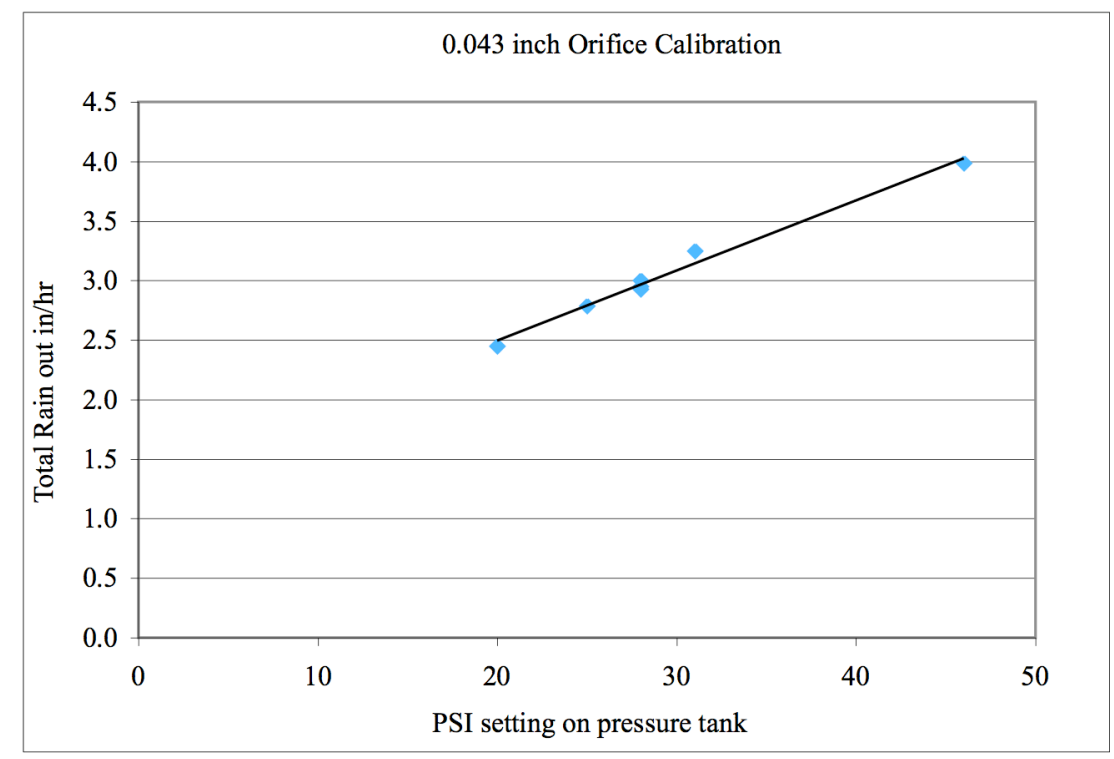

Figure 4: Rainfall obtained in inches per hour verses set pressure of the pressure tank using the 0.043 in orifice. 
The equation obtained from the least squares fit of the data $(y=0.0589 x+$ $\left.1.3171, \mathrm{R}^{2}=0.99\right)$, was used to determined that a setting of 28 running psi of the pressure tank should result in the desired $2.9 \mathrm{in} / \mathrm{hr}$ storm event for the duration of the test. The pressure gauge installed on the tank proved to be difficult to adjust with precision. The pressure inside the tank changed during each run. These observed changes of pressure were not consistent, with a result that the pressure sometimes increased or decreased slightly during a given run.

\section{Water Source}

Rainwater was simulated by carbon filtration of tap water. All water used for watering the planted trays, and for testing of the plant trays, came from tap water that had been filtered by a Culigan carbon filter just before use. To maintain consistency Culigan carbon filtered water was used for maintenance watering of all trays, as well as for all rainfall experiments.

\subsection{Greenroof Trays}

The greenroof trays used in this study were made from steel. Dimensions of the trays were $23.5 " \times 23.5 " \times 8.5 "$. Trays were folded into rectangles and edges were welded together. The trays were painted black to protect the metal from contact with air and water. Each tray had a 1" diameter drain hole drilled on one end that directed all runoff into the capture container. 
Drainage Layer

Trays were lined with Henry DB-50 greenroof drainage layer material that consists of three layers and is representative of a typical green roof membrane. The top layer is a thin filter fabric that keeps soil out of the second layer. The second layer is a $1 / 4$ inch molded plastic sheet containing small, circular dimples that have the ability to store water. The bottom layer is a waterproofing layer designed to keep the water and plant roots from contacting the roof below.

\section{Greenroof Planting Media}

Pro-Gro extensive mix has been used on several extensive (shallow soil) greenroofs in the Pacific Northwest. Pro-Gro's popularity made it a natural choice for this study. Pro-Gro extensive mix is a proprietary blend containing specially screened pumice, Fiber Life compost, and paper fiber. Fiber Life is an anaerobically digested dairy manure added as compost component and paper fiber is a clean, cellulose based product, added to increase friability to the soil mix. The estimated field moisture capacity of Pro-Gro Extensive mix is $45.7 \mathrm{lb} / \mathrm{ft}^{3}$ and the estimated saturated bulk density is $63.5 \mathrm{lb} / \mathrm{ft}^{3}$.

\subsection{Biochar}

The biochar used in this study was a 300 series blend from International Tech Corporation. The blend was $70.0 \%$ agricultural char, derived from the processing of rice hulls, pecan shells, walnut shells, and coconut shells, and 30.0\% manufactured waste char derived from pyrolysis of passenger car tires. The biochar ranged in size 
from very fine powder to pebble-sized chunks. To date there are no set guidelines to determine application rates of biochar to soil. A review of the literature covering past biochar soil applications revealed that soil application ranged from $0.5 \%$ to $20 \% \mathrm{w} / \mathrm{W}$ applications (Table 1).

Table 1: Quantities of biochar added to soil for a variety of studies.

\begin{tabular}{|c|c|c|c|}
\hline $\begin{array}{l}\text { Amount biochar } \\
\text { added }\end{array}$ & $\begin{array}{l}\text { Equivalent } \\
\text { Biochar in } \mathrm{lb} / \text { test } \\
\text { tray }\end{array}$ & $\% \mathrm{w} / \mathrm{w}$ & Reference \\
\hline 2.5 ton/acre & 0.46 & $0.6 \%$ & Dynamotive, 2007 \\
\hline 5.0 ton/acre & 0.918 & $1.2 \%$ & Dynamotive, 2007 \\
\hline $5 \mathrm{MgC} \mathrm{ha}^{-1}$ & 0.41 & $0.5 \%$ & Gaunt and Lehmann, 2008 \\
\hline $11 \mathrm{MgC} \mathrm{ha}^{-1}$ & 0.901 & $1.1 \%$ & Gaunt and Lehmann, 2008 \\
\hline $140 \mathrm{MgC} \mathrm{ha}^{-1}$ & 11.47 & $14.6 \%$ & Rondon et al., 2007 \\
\hline $10 \% \mathrm{w} / \mathrm{w}$ & 7.87 & $10.0 \%$ & Lehmann et al., 2003 \\
\hline $20 \% \mathrm{w} / \mathrm{w}$ & 15.74 & $20.0 \%$ & Lehmann et al., 2003 \\
\hline
\end{tabular}

Biochar was added to Pro-Gro extensive mix at 7\% w/w for this study. Seven percent was chosen as a concentration in the middle of the range of previous studies and to work with the limited supply of biochar available.

\subsection{Plants}

Due to the number of variables already introduced to the experiments, only one plant species was planted per set of trays. The three plant species were sedum (Sedum hispanicum), ryegrass (Lolium perenne), and vinca major (Catheransus roseus).

Vinca major is also commonly known as big-leaf perwinkle. All three plant species were chosen for their ability to survive in previous studies performed in Portland State University's Green Roof Test and Design Laboratory. 
$\underline{\text { Sedum }}$

Sedums have proven to be very successful greenroof plants. Sedum hispanicum is a succulent of the crassulaceae family and is native to southeastern Europe and southwestern Asia. An evergreen herbaceous perennial, it is hardy in USDA zones 2-9 and grows 2-3 inches high. Recommended growth conditions are full sun in ordinary to poor, dry, well-drained soil (Saylor, 2008). Sedum hispanicum has been successfully grown on the Hamilton Building greenroof owned by the city of Portland.

\section{$\underline{\text { Ryegrass }}$}

Ryegrass (Lolium perenne) is a perennial ryegrass with medium moisture and fertility requirements, and is adapted to coarse and medium textured soils such as those typically found in greenroof soils (USDA, 2010). Although ryegrass is listed as having a low tolerance to drought (USDA, 2010), ryegrasses planted in the greenroofs trays have been observed to survive a fair amount of neglect. The ryegrass seed used was a 3-way Perennial Ryegrass blend from Hobs and Hokins Ltd., that consisted of 40.41\% PR8820 Perennial Ryegrass, 29.25 \% Top Hat 2 Perennial Ryegrass, and 29.25 Gator 3 Perennial Ryegrass.

$\underline{\text { Vinca }}$

Vinca Major (Catheransus roseus) is a broadleaved, variegated, evergreen with single, 5-petalled, 1-inch, lilac blue flowers. Vinca is hardy in USDA zones 6-9 
(Saylor, 2008). A showy plant, it was chosen for its ability to survive a fair amount of neglect with little signs of distress in the Portland State University greenhouse.

\subsection{Assembly and Planting of Greenroof Trays}

In preparation for planting, each tray was lined with Henry DB-50 greenroof membrane. Eight trays were filled with Pro-Gro soil. The other eight trays were filled with Pro-Gro soil that had been amended with Biochar at a 7\% weight-by-weight ratio. All trays were filled to an even 6" soil depth. Two trays of each soil type were kept barren as soil-only controls. The remaining trays were then planted with sedum, ryegrass, or vinca. Sedum was planted by taking cuttings from existing trays of mature sedum plants. The cuttings were spread out over the soil and gently misted until they had taken root. Ryegrass was planted from seed. These trays were also lightly misted until the seedlings had grown up and were strong enough to handle normal watering. Vinca was started by placing trays of empty soil adjacent to trays with runners to allow the runners to put out starts into the trays of bare soil. This approach proved to have limited success within the necessary timeframe causing vinca-planted trays to be removed from the study due to lack of plant cover in the trays. Trays were labeled as shown in Table 2. 
Table 2: Tray labels for the Different Soil and Plant Types.

\begin{tabular}{|c|c|c|}
\hline \multicolumn{3}{|c|}{ Tray Labels } \\
\hline \multirow{2}{*}{ Soil-Only } & $\begin{array}{c}\text { Pro-Gro } \\
\text { Trays }\end{array}$ & $\begin{array}{c}\text { Biochar } \\
\text { Trays }\end{array}$ \\
\cline { 2 - 3 } & P4 & B2 \\
\hline \multirow{2}{*}{ Sedum } & P5 & B3 \\
\cline { 2 - 3 } & P2 & B6 \\
\hline \multirow{2}{*}{ Ryegrass } & P3 & B7 \\
\cline { 2 - 3 } & P6 & B4 \\
\hline \multirow{2}{*}{ Vinca } & P1 & B1 \\
\cline { 2 - 3 } & P8 & B8 \\
\hline
\end{tabular}

All trays were sustained in the Portland State University Center for Lakes and Reservoirs Greenhouse (Figure 5) and only removed for testing in GERTY. Planted trays were watered with just enough water to allow the seeds or cuttings to grow. Every attempt was made to keep the trays from receiving too much water to prevent resulting drainage. After growth of the seeds or cuttings, watering continued to be very light. Soil-only control trays received roughly the same amount of water as the planted trays in order to maintain the existing microbial communities in the soil. 


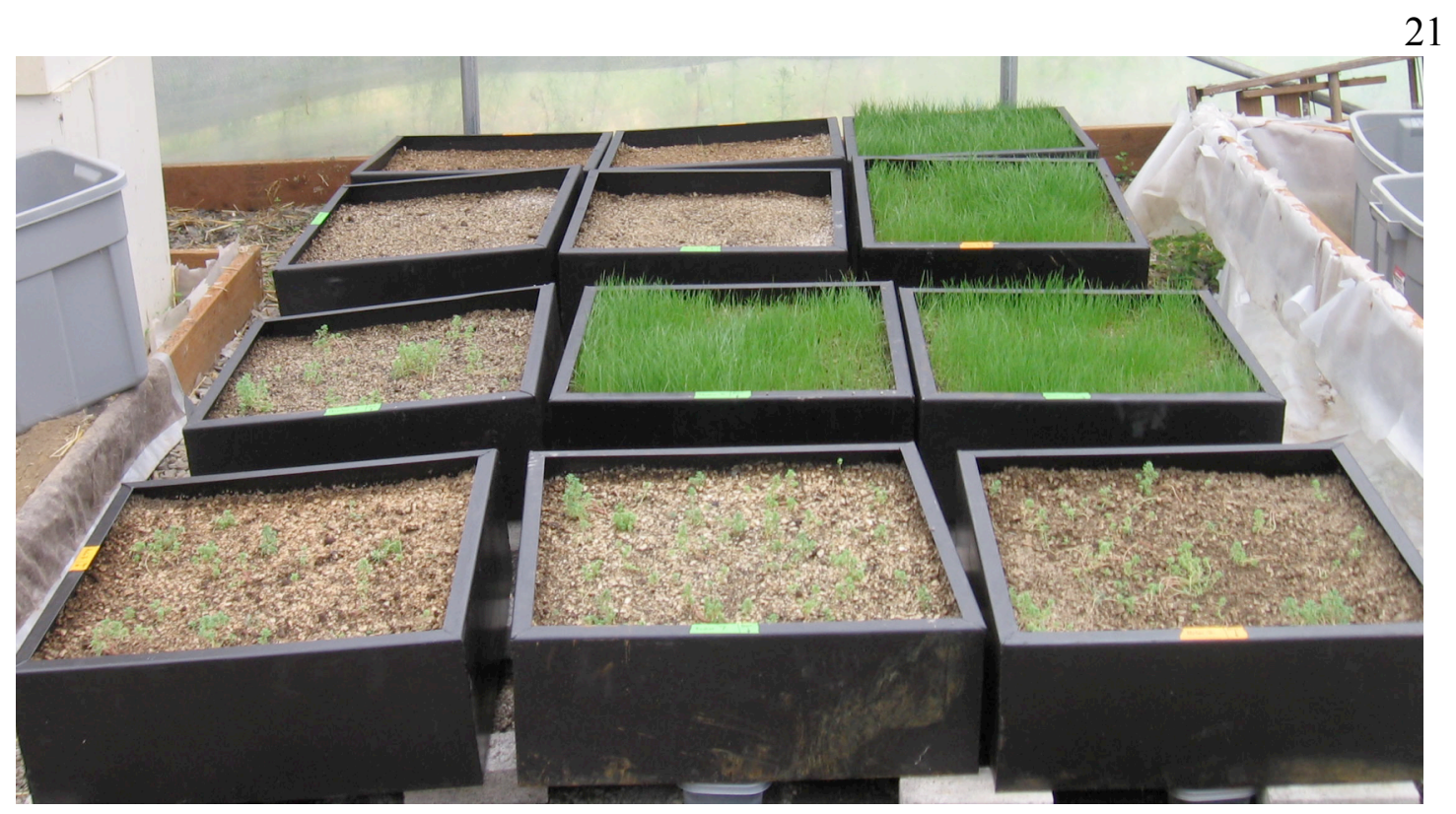

Figure 5: Planted trays. Soil-only controls (upper left), sedum (front row and 2nd from lower left), and ryegrass a few weeks after planting.

\subsection{Storm Intensity and Length}

Storm events were designed with an emphasis placed on optimizing phosphorus testing. In determining the storm intensity and length the National Phosphorus Protocol Research Project was referenced. "The field objectives of the National Phosphorus project are to characterize soil test $\mathrm{P}$ (STP) - runoff $\mathrm{P}$ relationships for a representative cross-section of important agricultural soils across all Major Land Resource Areas in the U.S.” (National Phosphorus Protocol, 2005).

The National Phosphorus Protocol calls for two rainfall events 24 hours apart at a rainfall intensity of approximately $70 \mathrm{~mm} / \mathrm{hr}$ or at an intensity corresponding to a tenyear storm for the geographical locations. An intensity of $70 \mathrm{~mm} / \mathrm{hr}$ allows comparisons between sites, while use of a ten-year storm rainfall allows approximation of local conditions. Runoff for both events is collected over 30 
minutes. The first rainfall event was conducted at site soil moisture conditions. The rainfall event was heavy enough to allow for the assumption that the site will be at approximately field capacity for the second rainfall. Storm intensity and length for this study were modeled after the Nation Phosphorus Protocol with a few changes to accommodate lab testing verses field testing.

1) Rained for $30 \mathrm{~min}$. Collected until runoff stopped (versus collecting for only 30 minutes of runoff time).

2) Increased storm intensity to $74 \mathrm{~mm} / \mathrm{hr}$ from $70 \mathrm{~mm} / \mathrm{hr}$ to coincide with Portland, OR 5-year 24-hour storm event (Bureau of Environmental Services, 2007).

3) Time between rainfall events was shortened to two hours. This proved sufficient to allow runoff from the trays to cease flowing, and to keep the conditions of the plants as consistent as possible.

\section{$\underline{2.8 \text { Final Testing Protocol }}$}

For the first rainfall event (Run A), the rainfall simulator was run for 30 minutes at $2.9 \mathrm{in} / \mathrm{hr}$. Samples were collected from every liter of rainfall runoff per tray, and the time of collection recorded. Sample collection continued until rainfall runoff stopped or two hours had passed. Two hours after stopping Run A, the second rainfall event was performed using the same protocol as used for Run A. Two hours after Run $\mathrm{B}$, the test was declared finished and weight datalogging was terminated. Starting and ending volumes in the pressure tank were recorded and tank water samples from each run were collected. 


\subsection{Runoff Water Sample Collection}

In order to equalize sample collection, samples were collected after each liter rainfall runoff came through each tray. Each tray had one drain hole that was lined up and sealed to the matching drainhole in the test bed. Each drain hole had a drainage tube attached. These drainage tubes each drained into separate 1-liter Erlenmeyer flasks (Figure 6). Time of collection of each sample was also recorded. Depending on whether both a FIA and TOC sample were being collected at the same time or whether just a FIA sample was being collected, samples were taken either after $910 \mathrm{ml}$ had flowed through the tray or after $950 \mathrm{ml}$ had flowed through the tray, in order for the total runoff to equal 1.0 liter. FIA sample collection tubes were $50 \mathrm{ml}$, and TOC collection tubes were $40 \mathrm{ml}$. For all tests except ryegrass testing, TOC samples were taken every other liter of runoff. As ryegrass testing was performed last and more data was desired, both TOC and FIA grab samples were taken at every liter of rainfall runoff.

When the draining water had reached an appropriate level the drainage tube was removed from the flask, a collection tube was inserted underneath the drainage tube and grab samples were collected. This resulted in samples being collected midstream instead of in mixed batches. 


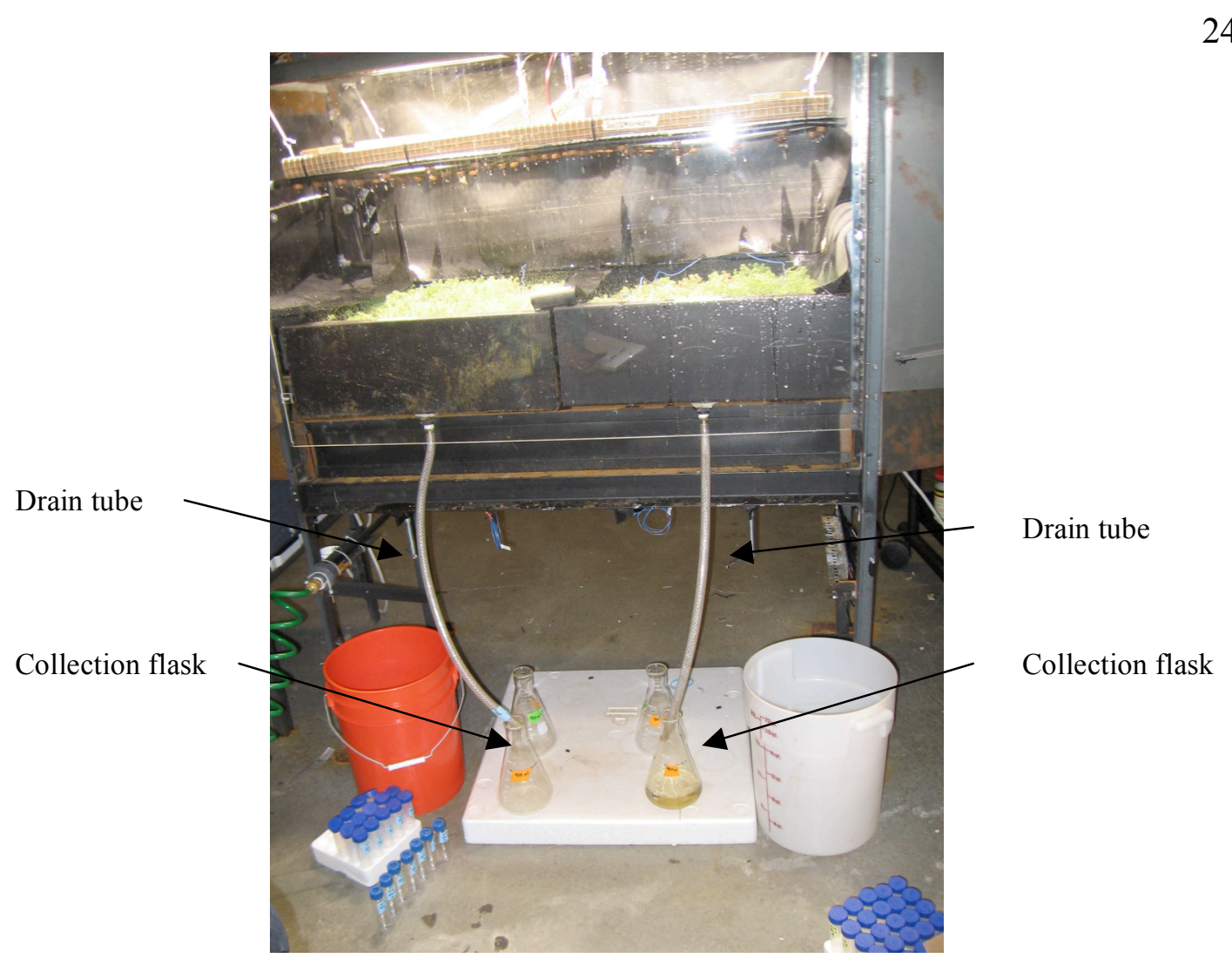

Figure 6: Experiment setup in GERTY showing drainage tubes positioned over 1-liter Erlenmeyer flasks and sample collection tubes ready for use.

\subsection{Sample Preservation}

All samples were kept at $4^{\circ} \mathrm{C}$ until processing. All TOC samples were processed within three days of sample collection. Aliquots were taken from all samples collected in 50-ml conical tubes for nitrate and phosphate testing on the FIA. These aliquots were tested within 48 hours of collection. After aliquots are pulled off for nitrate and phosphate testing the remaining sample volume was treated with acid in accordance with EPA method 365.2 which specifics using sulfuric acid $\left(\mathrm{H}_{2} \mathrm{SO}_{4}\right)$ at concentrations equivalent to $2 \mathrm{~mL} \mathrm{H}_{2} \mathrm{SO}_{4}$ per liter. After acid was added to the sample the samples were gently mixed and then placed at $4^{\circ} \mathrm{C}$ for storage. 


\subsection{Sample Processing}

\section{Total Organic Carbon}

Total carbon (TC), inorganic carbon (IC), and total organic carbon (TOC) were determined in the collected runoff water samples using a Shimadzu TOC-V CSH. The Shimadzu TOC-V CSH is a high-sensitivity total organic carbon analyzer that uses a platinum-aided catalytic oxidation at $680^{\circ} \mathrm{C}$ to perform complete combustion of each sample.

Total carbon is measured by injecting the sample into the catalyst filled combustion tube where the total carbon in the sample is oxidized or decomposed to create carbon dioxide. Carrier gas carries the combustion products from the combustion tube. The carrier gas is cooled and dehumidified before passing into a sample cell of the non-dispersive infrared detector (NDIR), where the carbon dioxide is detected. The peak area created by the NDIR analog signal is calculated by the data processor and converted to parts per million (ppm) reading. Total carbon is the sum of both organic carbon and inorganic carbon.

The Shimadzu TOC measures inorganic carbon in the sample by acidifying the sample with phosphoric acid. This acidified sample is then sparged with ultra-purified air, which proceeds to convert only the inorganic carbon in the sample to carbon dioxide. The resulting carbon dioxide is then detected by the NDIR and the sample's inorganic carbon concentration is measured in the same way as total carbon. In this case, inorganic carbon is a combination of carbonate and bicarbonate. 


\section{$\underline{\text { FIA }}$}

The FIA 2500, a flow injection analyzer, was used to determine concentrations of nitrate, phosphate, total nitrogen, and total phosphorus in each collected runoff water sample. The FIA 2500 uses spectrophotometry and colorimetric assays to determine the desired analyte concentration. Samples are injected into carrier and reagent solutions. The desired chemical reactions take place in-flow and the fluid is transported into a VIS detector zone. Absorbance of the sample fluid is measured and the quantity of the target analyte is determined.

\section{FIA 2500 Description:}

Four channel peristaltic pump, 6 port injection valve.

FIA manifold set up with $1 \mathrm{~cm}$ flowcell

USB 4000 VIS Spectrometer

LS-1-LL Tungsten halogen light source

ASX-260 Cetac Autosampler

Flow through heater (for phosphate assays)

Cadmium column (for nitrate assays)

\section{Control Computer}

Dell Optiplex with Windows Visa, FIAlab software, methods, drivers 19" monitor. 


\section{FIA Protocols}

For all FIA testing, a sample loop of three inches and a 1-cm flowcell were used. The FIA can mix up to three different reagents with the sample. These are normally referred to as Carrier, Reagent 1, and Reagent 2. Chemical solutions of the carrier and reagents varied depending on the assay being performed.

\section{$\underline{\text { Nitrate Protocol }}$}

Measurement of nitrate concentrations was accomplished through use of a copperized cadmium column attached to the FIA 2500. The column catalyzed the reduction of nitrates into nitrites. The resulting nitrites then reacted with sulfanilamide to form azo dyes that coupled with N- (1-Naphthyl) ethylenediamine dihydrochloride and formed a magenta colored solution. The azo dye solution was quantified at 540 $\mathrm{nm}$ and is proportionate to the quantity of nitrate/nitrite present in the initial sample.

To process nitrate, a Lachat Instruments cadmium column was connected to the FIA LOV Manifold "B" ports. Standards were made in a range of concentrations using Exaxol Chemical Corp. Nitrate Standard $1000 \mathrm{mg} / \mathrm{l}, \mathrm{NO}_{3}$, by diluting with nanopure water. Nanopure water was used as both standard diluent and $0 \mathrm{mg} / \mathrm{l}$ blank.

\section{Phosphate Protocol}

Phosphate concentrations were determined through reactions with molybdate anions. A yellow-colored phosphomolybdate complex results from these reactions. Ascorbic acid is then used to create a molybdenum blue species with an absorbance 
range of $700 \mathrm{~nm}$ to $900 \mathrm{~nm}$. This absorbance of the molybdenum blue species is used to determine phosphate concentrations in the sample. This method is designed to determine reactive phosphorus only, where reactive phosphorus is defined as hydrolyzed orthophosphates.

For processing phosphate samples on the FIA, the heater was set to $45^{\circ} \mathrm{C}$ and standards were made up from Exaxol Chemical Corp. Phosphate Standard $1000 \mathrm{mg} / \mathrm{l}$, diluting with nanopure water as appropriate.

\section{Total Phosphorous and Total Nitrogen Protocol}

In order to determine total phosphorous and total nitrogen of the sample, the samples were simultaneously digested by a persulfate method. The purpose of the digestion is to break free the elemental phosphorus and nitrogen and then convert the elemental phosphorus and nitrogen to phosphate or nitrate.

Runoff samples were digested for analysis of total nitrogen and total phosphorus using a simultaneous digestion that converts organic nitrogen and ammonium to nitrate and phosphorus compounds to phosphate. Digestion was performed in accordance to the simultaneous digestion protocol written by University of Minnesota's soil and water laboratory (Owen et al., 1992). The digestion used potassium persulfate $\left(\mathrm{K}_{2} \mathrm{~S}_{2} \mathrm{O}_{8}\right)$ and $\mathrm{NaOH}$ to create an alkaline oxidizing system. The digestion was performed in an All American Electric Pressure Steam Sterilizer, Model 25X. Samples were digested in the steam sterilizer for a minimum of 35 minutes at 17 to $21 \mathrm{psi}$. 
The digestion protocol was adapted to process smaller samples. All concentrations and ratios of chemicals were kept consistent. After digestion, phosphate and nitrate FIA protocols were run on samples to obtain total phosphorus and total nitrogen concentrations. All reagents used were the same as for phosphate and nitrate testing.

\section{$\underline{2.12}$ Total Dissolved Solids and Suspended Sediment Concentration}

Turbidity in runoff samples was evaluated for total dissolved solids (TDS) and suspended sediment concentration (SSC). As there is no discernable sediment, suspended sediment concentration is an appropriate test for the runoff samples and results should be considered equivalent to total suspended solids (Gray et al., 2000).

Samples were collected from Pro-Gro ryegrass tray [P6] and biochar ryegrass tray [P5], for every other liter of flowthrough. Trays were first subjected to Run A of 30 minutes at $2.9 \mathrm{in} / \mathrm{hr}$ of rainfall from the rainfall simulator. Trays sat for 2 hours and then the rainfall simulator was turned on for another 30 minutes, at a rate of $2.9 \mathrm{in} / \mathrm{hr}$. Samples were collected from this second rainfall event (Run B). Total dissolved solids were measured on a $\mathrm{pH} /$ conductivity/TDS meter. Suspended sediment concentration was determined by evaporation as described in Shreve et al. (2005), and values were calculated from the net weight after total sample evaporation using Equation 1. Samples were aliquoted into pre-weighed vials and oven-dried overnight at $80^{\circ} \mathrm{C}$. Temperature was then raised to $109^{\circ} \mathrm{C}$ for 4 hours. Vials were again weighed. Net weight gain is suspended sediment concentration. 


$$
\begin{aligned}
\mathrm{TDS}+\mathrm{SSC} \mathrm{mg} / 1 & =\frac{\text { Net evaporated weight } \mathrm{g} \times 1000 \mathrm{mg} / \mathrm{g}}{(\text { volume sample in } \mathrm{ml} / 1000 \mathrm{ml} / \mathrm{L})} \\
\mathrm{SSC} & =(\mathrm{TDS}+\mathrm{SSC})-\mathrm{TDS}
\end{aligned}
$$

\section{$\underline{2.13 \text { Nitrate Soil Extraction }}$}

Two trays, a ryegrass Pro-Gro tray [P6] and a sedum biochar tray [B6] showed higher levels of nitrate than expected in the collected runoff. Theorizing that the heterogeneity of the soil could have resulted in richer sources of nitrate in some trays than in others, a nitrate soil extraction was performed on soil cores taken from the above trays.

Cores were taken by using a hand shovel to pull up 'core' of dirt and a small amount of soil collected along the length of the 'core'. Four samples were taken from each tray, one sample from each quadrant. Two samples from each tray were combined into the other two samples from each tray yielding two samples per tray.

Samples were taken from Pro-Gro ryegrass trays [P6 and matching P3], biochar sedum trays [B6 and matching B7], and two soil-only controls, one Pro-Gro [P4] and one biochar [B3] to allow for comparisons of the different trays. Samples were weighed. Nanopure water was added at a 2:1 ratio and samples were mixed endover-end for 5 minutes. Samples were filtered $(0.45 \mu \mathrm{m})$ and processed on the FIA for nitrate. 


\subsection{RESULTS AND DISSCUSION}

\subsection{Pro-Gro Soil versus Biochar-Amended Soil for All Trays}

The overall effect of adding 7\% biochar to Pro-Gro greenroof soil in terms of nutrient retention was evaluated by comparing nutrient concentrations of the rainfall runoff from the 6 trays containing biochar-amended soil to the 6 trays containing ProGro soil. The 6 trays of biochar-amended soil demonstrated increased retention of nitrate, total nitrogen, phosphate, total phosphorus, and total organic carbon compared to the trays of Pro-Gro soil. Nutrient concentrations in the rainfall runoff for all 12 trays were evaluated by examining the cumulative distribution graphs of each nutrient. Measured concentrations of each nutrient measured from all samples were sorted by soil type and plotted against the probability of the occurrence of each concentration. The cumulative distribution graphs show the probability or percent chance that a measured concentration is greater than or equal to all other measured concentrations. When viewing a cumulative distribution graph it is important to note that shadowed or even overlapping values can still be from significantly different populations. Bootstrap Kolmogorov-Smirnov analysis (Sekhon, 2009) was performed on the distributions to determine significance of observed differences between the two soil types. Individual results and significance of results of each nutrient are discussed in subsequent sections.

\section{Total Organic Carbon}

Biochar-amended soil showed a significant difference (Kolmogorov-Smirnov p-value $2.20 \mathrm{e}-16$ ) of the amount of total organic carbon released into the rainfall 
runoff (Figure 7) when compared to Pro-Gro soil. The cumulative distribution graph shows a clear difference between total organic carbon concentrations released by the two soil types. Biochar-amended soil had a reduction of total organic carbon concentrations in the rainfall runoff from all soil and plant trays, by a factor of 3 to 4 when compared to Pro-Gro soil.

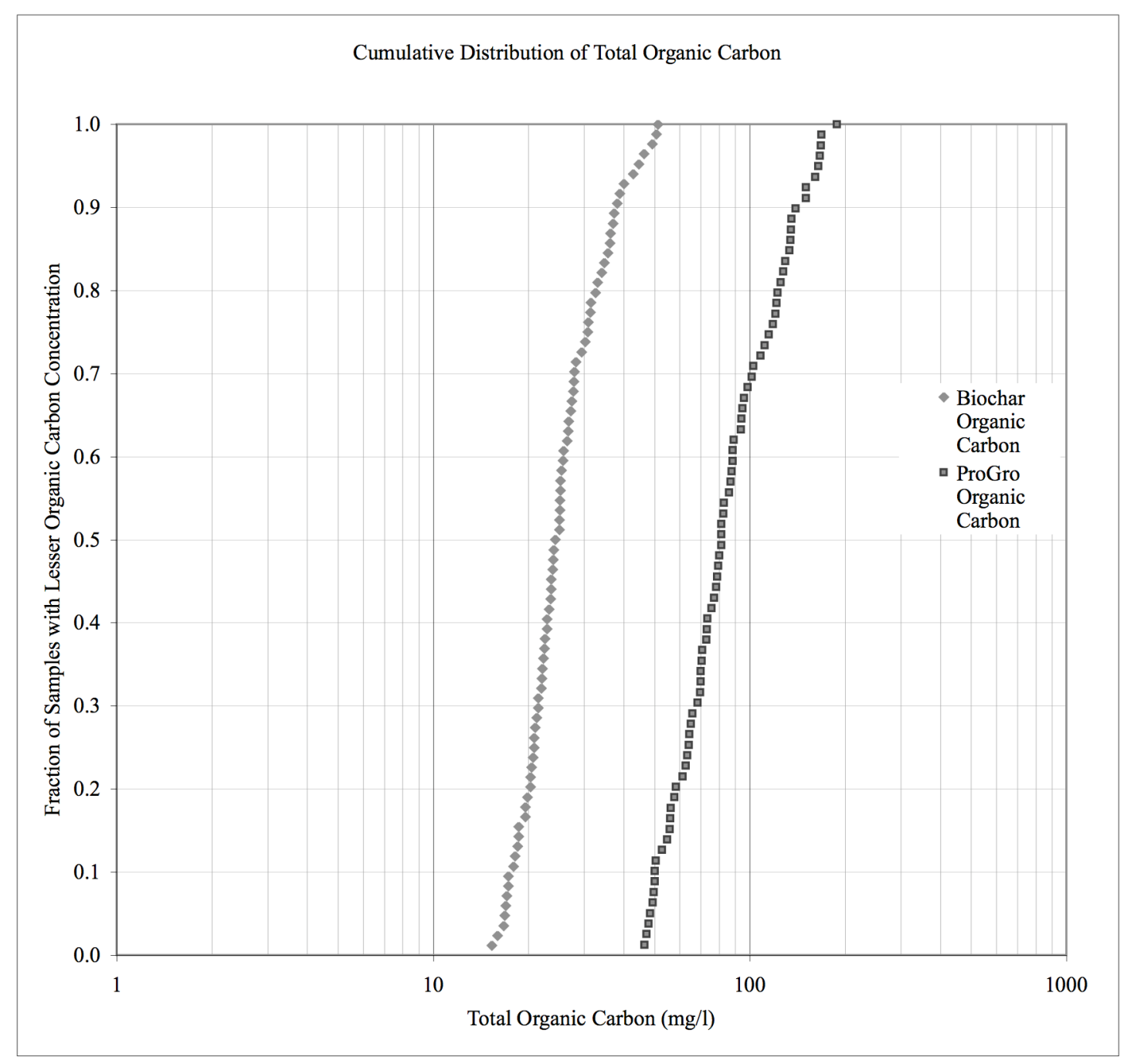

Figure 7: Cumulative distribution graph of rainfall runoff total organic carbon concentrations measured from all samples. 
The significant differences seen in the organic carbon concentrations of the rainfall runoff of the two soils are also seen visually by comparing color, or turbidity, of the rainfall runoff samples. This visual difference in turbidity is seen in Figure 8, where rainfall runoff samples from Pro-Gro soil trays have a tea or brown color, and the biochar-amended rainfall runoff samples are almost clear.

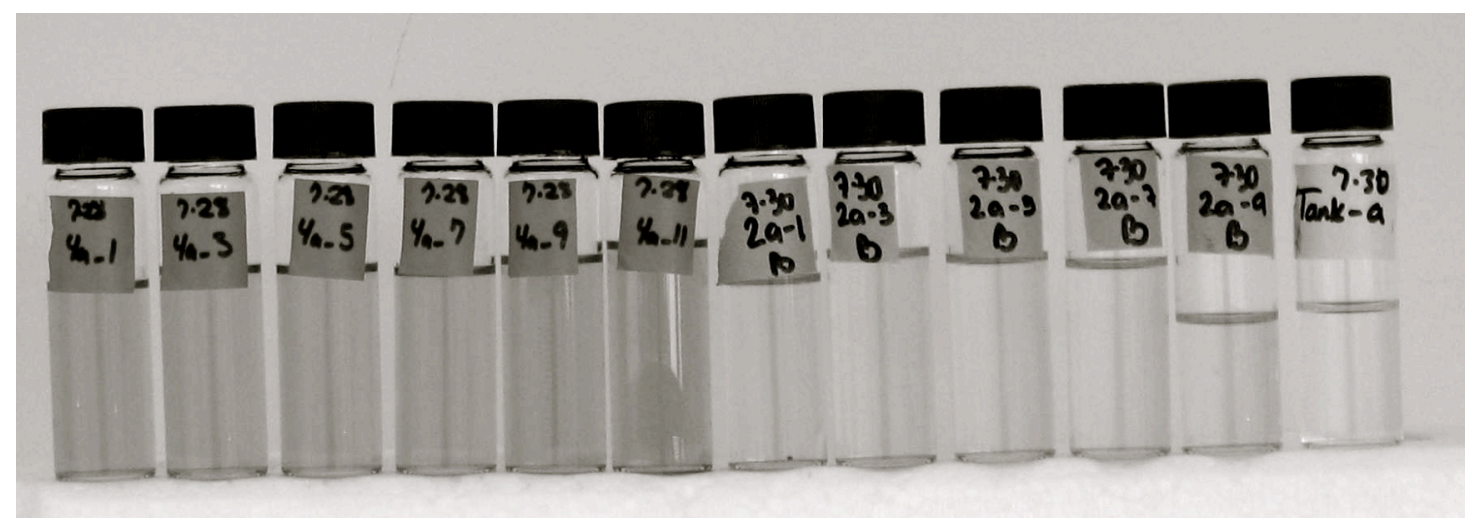

Figure 8: Rainfall runoff samples from soil-only trays. First 6 samples from left are from a Pro-Gro soil-only tray. Next 5 are from a biochar soil-only tray. Sample labeled 'Tank-a' is source water for the rainfall experiments.

\section{$\underline{\text { Inorganic Carbon }}$}

In stark contrast to the total organic carbon results, inorganic carbon results showed no significant difference (Kolmogorov-Smirnov p-value 0.153) of inorganic carbon concentrations between rainfall runoff from Pro-Gro soil or biochar-amended soil (Figure 9). Inorganic carbon for this study is defined as being in the form of carbonate or bicarbonate. In this experiment, inorganic carbon in the forms of carbonate and bicarbonate showed no tendencies to either react with or to be retained by biochar-amended soil. The presence of biochar in the soil did not contribute to the amount of inorganic carbon concentrations in the rainfall runoff. 


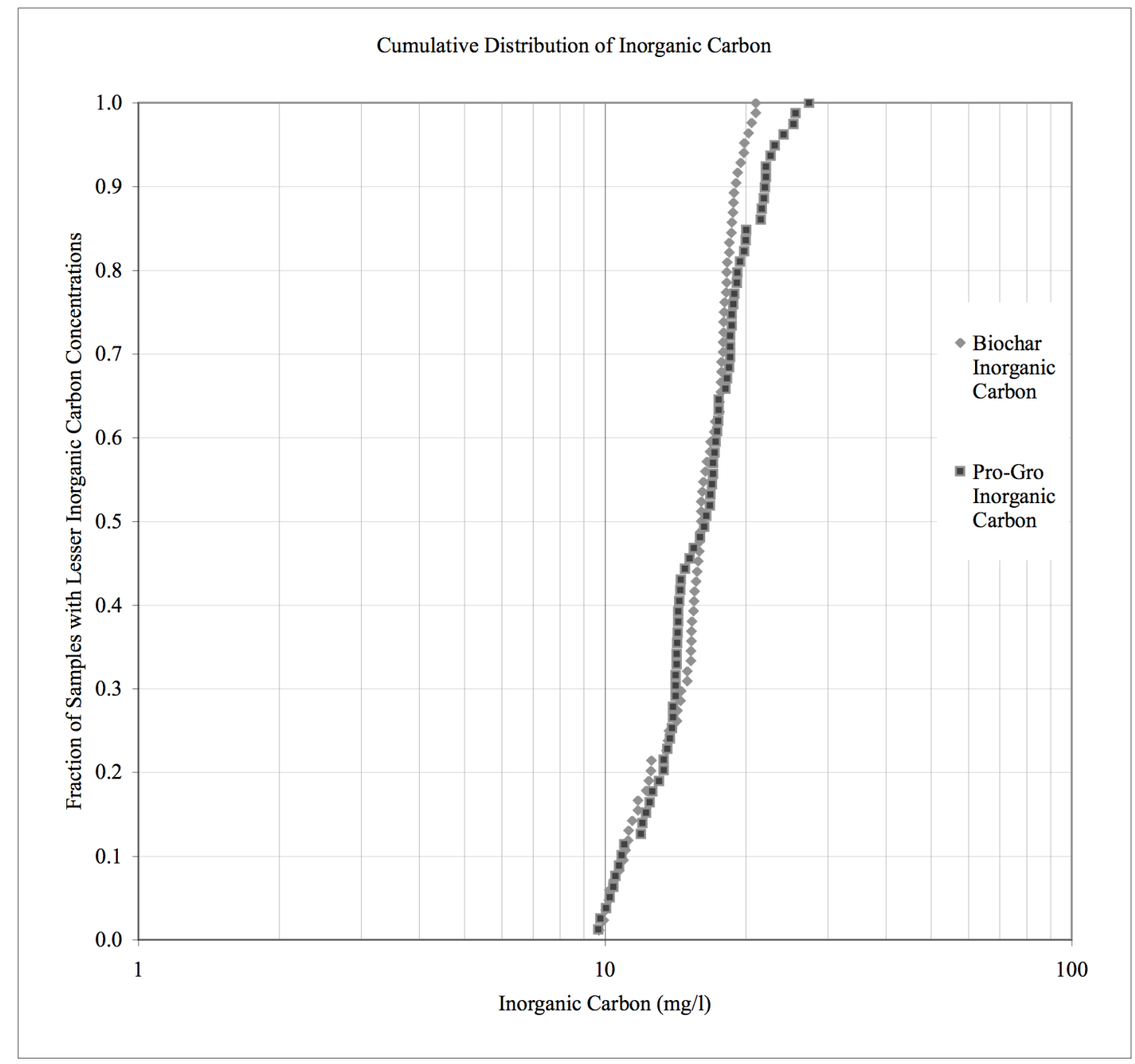

Figure 9: Cumulative distribution graph of rainfall runoff inorganic carbon concentrations measured from all samples.

\section{Nitrate}

Biochar-amended soil resulted in significantly decreased nitrate levels in the rainfall runoff (Kolmogorov-Smirnov p-value 3.804e-14) when compared to rainfall runoff obtained from trays containing Pro-Gro soil (Figure 10). Biochar-amended soil increased nitrate retention by a factor of 3 to 25 . For example, at the 0.57 fraction of samples, biochar-amended soil rainfall runoff has a concentration of $33 \mathrm{mg} / \mathrm{l}$ and Pro- 
Gro soil rainfall runoff has a concentration of $103 \mathrm{mg} / \mathrm{l}$, or a factor of 3 difference between the two samples. The nitrate assay uncertainty analysis yielded an error of $\pm 1.0 \mathrm{mg} / \mathrm{l}$ for nitrate concentrations. Even at the lowest concentrations measured, 0.4 $\mathrm{mg} / \mathrm{l}$ from biochar-amended rainfall runoff and $9.9 \mathrm{mg} / \mathrm{l}$ from Pro-Gro rainfall runoff, an error of $\pm 1.0 \mathrm{mg} / 1$ still yields clear differences in nitrate concentrations well outside the range of error. The cumulative distribution graph of all measured concentrations of nitrate for both soils, shows that both biochar-amended soil and ProGro soil exhibit similarly shaped curves both above and below the median in Figure 10. This signifies a scaling factor or a multiplicative shift versus an arithmetic shift, which also points to biochar-amended soil having a significant effect on the retention of nitrate for all trays tested. 


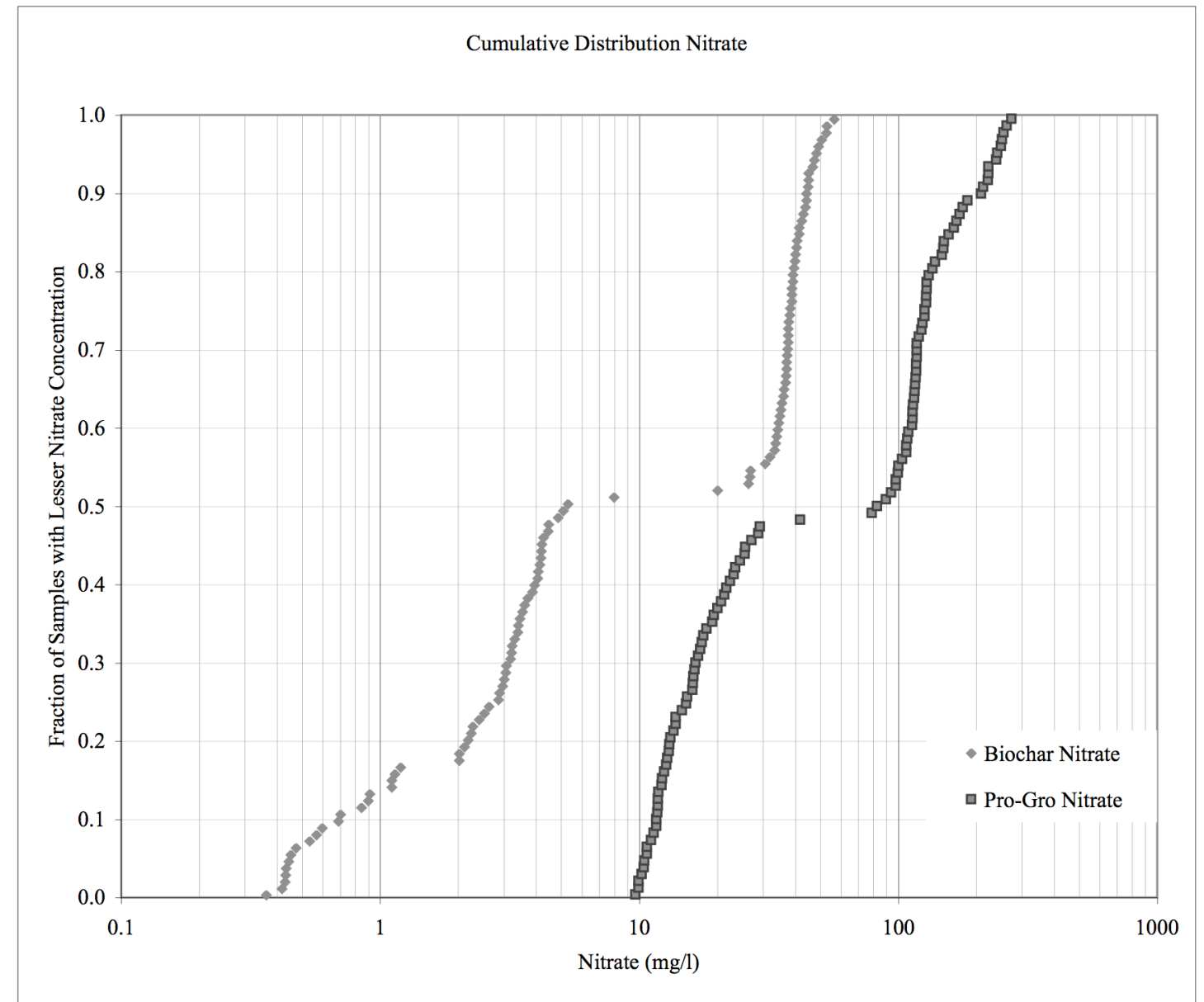

Figure 10: Cumulative distribution graph of rainfall runoff nitrate concentrations measured for all samples and fraction of nitrate released by each plant and soil type (inset graph).

The split seen for the biochar-amended soil is a result of one biochar-amended sedum tray releasing low concentrations of nitrate (range of 2 to $8 \mathrm{mg} / \mathrm{l}$ ) and the matching biochar-amended sedum tray releasing higher values of nitrate (range of 30 to $52 \mathrm{mg} / \mathrm{l})$. A similar event occurs with the Pro-Gro soil ryegrass trays, with one tray releasing values of nitrate below the median (range of 10 to $17 \mathrm{mg} / \mathrm{l}$ ), and the matching Pro-Gro soil ryegrass tray releasing high values of nitrate above the median (range of 79 to $172 \mathrm{mg} / \mathrm{l}$ ). 
The breakdown of fraction of nitrate samples matched to each soil type and plant type are shown in Figure 11. The boxplots shown in Figure 11 show the median, third and first quartile as edges of each box, and the full range of all values obtained per tray. Examination of the distribution of the fraction of nitrate values from each tray reveals that the split observed in the nitrate concentrations of both soils around the median in Figure 10, is a result of each tray either releasing nitrate values above the median, or releasing nitrate values below the median. Out of all tested trays, only two trays released ranges of concentration values that crossed the median (trays B7 and P6), from these two trays 40 samples were collected. Out of those 40 samples, only 3 had values that crossed the median.
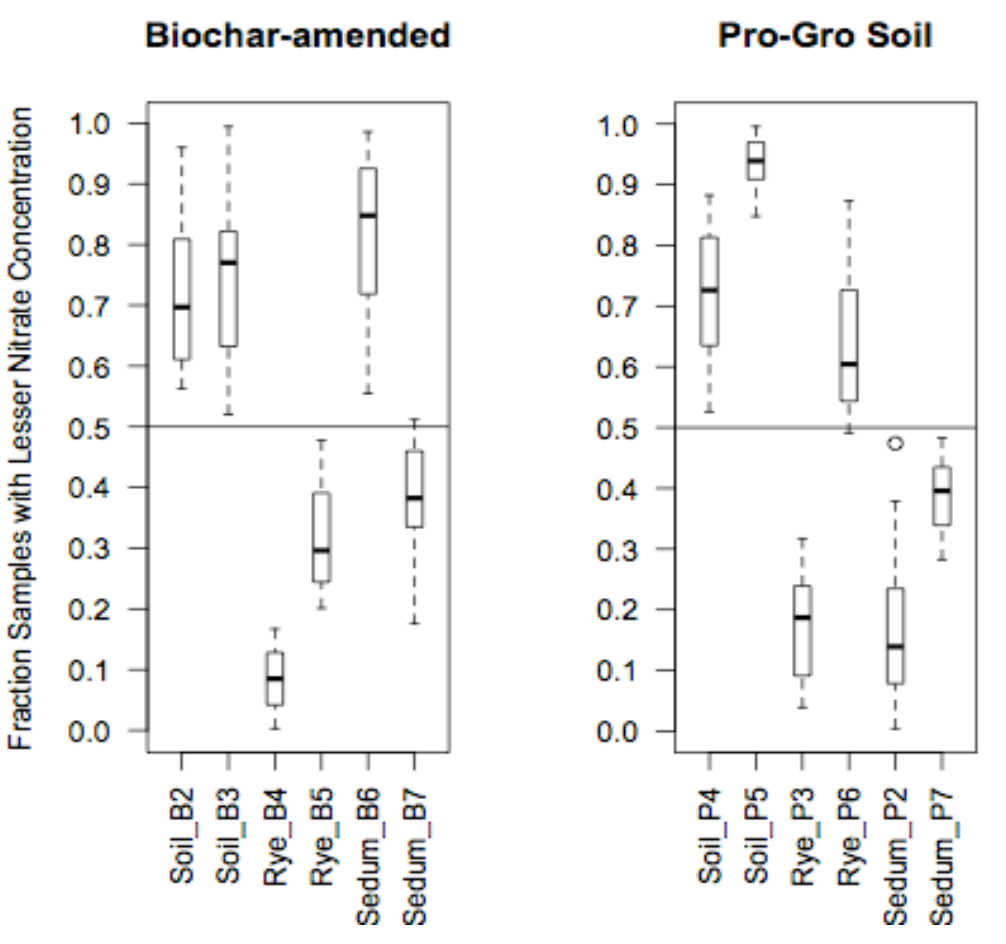

Figure 11: Boxplots showing breakdown of fractions of nitrate samples resulting from each soil type and plant type. Boxes show median, interquartiles at edges of box, and range of 1.5 times the interquartile range. Outliers are shown as circles. Note how only two trays have any values that cross the median at 0.5 . 
Admittedly, the nitrate curves do have an interesting shape, but as these values are obtained from raw data, they are expected to exhibit variability. This variability shows that in real world situations where soil is non-homogenous, biochar-amended soil still has a clear effect on the amount of nitrate in the rainfall runoff. That the two curves are clearly from different populations (Kolmogorov-Smirnov p-value 3.804e14) leads to the conclusion that biochar-amended soil reduces the amount of nitrate entering the rainfall runoff.

\section{Total Nitrogen}

Total nitrogen values are only valid for the ryegrass trays as all other total nitrogen samples had been compromised by acid preservation. The total nitrogen results collected from the trays planted with ryegrass show that trays with biocharamended soil released significantly different total nitrogen concentrations than trays containing Pro-Gro soil (Kolmogorov-Smirnov p-value 2.592e-16) (Figure 12). The trays with biochar-amended soil showed a reduction of total nitrogen entering the rainfall runoff by a factor of 5 to 10 . The graph of the cumulative distribution of total nitrogen displays a concentration jump between the two matching Pro-Gro soil ryegrass trays at the 0.37 fraction of samples point. This gap is due to the rainfall samples coming from two matching, but not identical, trays. It is suspected that one Pro-Gro soil ryegrass tray simply contained a much larger source of nitrogen than the other Pro-Gro soil ryegrass tray. 


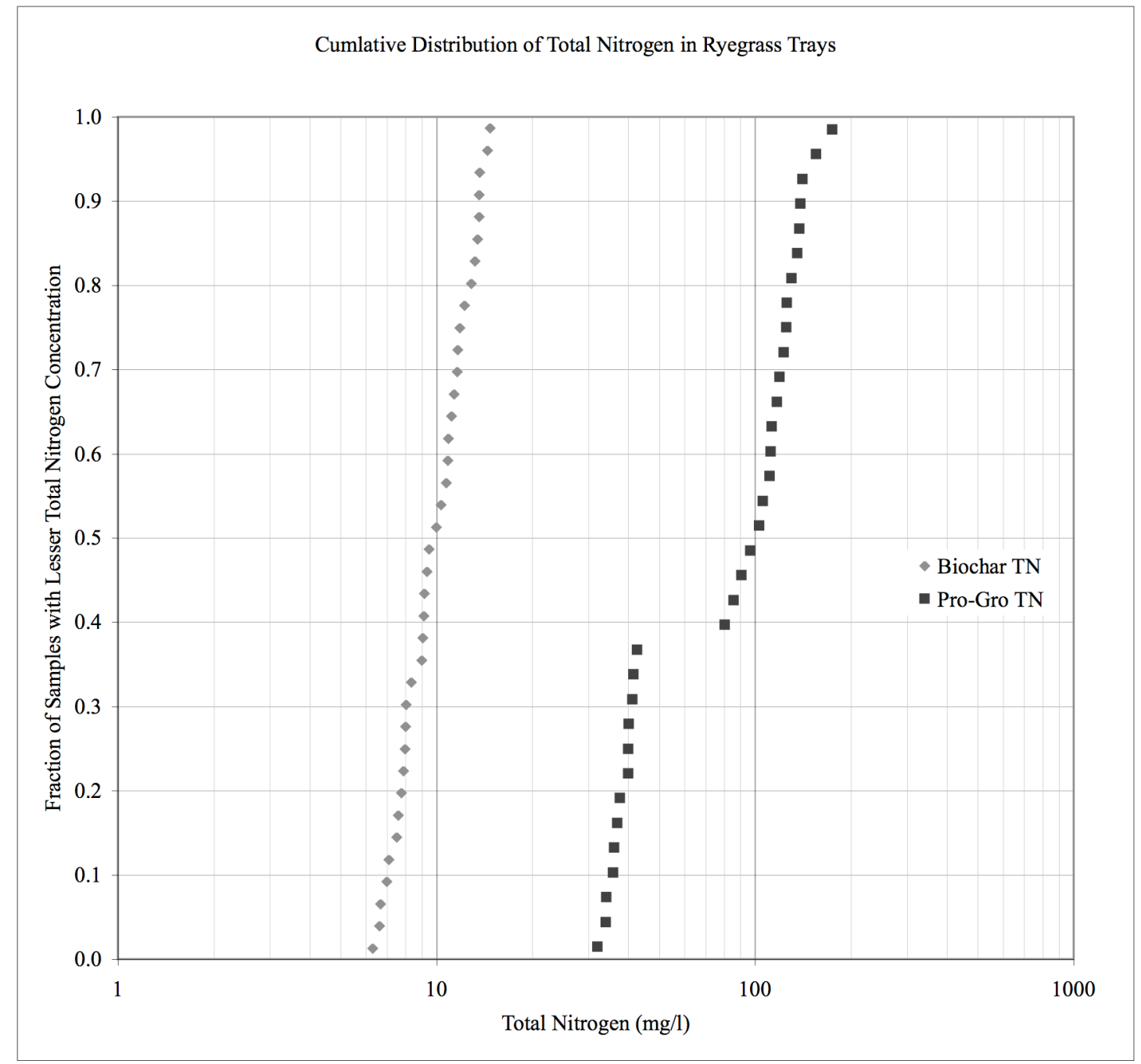

Figure 12: Cumulative distribution graph of rainfall runoff total nitrogen concentrations measured from all samples from ryegrass trays.

Phosphate

A comparison of all obtained phosphate concentration values for both soil types reveals a reduction of phosphate in the rainfall runoff from trays containing biochar-amended soil except when sedum is planted in the trays (Figure 13). Analysis of the two curves from the two different soil types yields a Kolmogorov-Smirnov p- 
value of $2.20 \mathrm{e}-16$, revealing that the two curves are significantly different from each other.

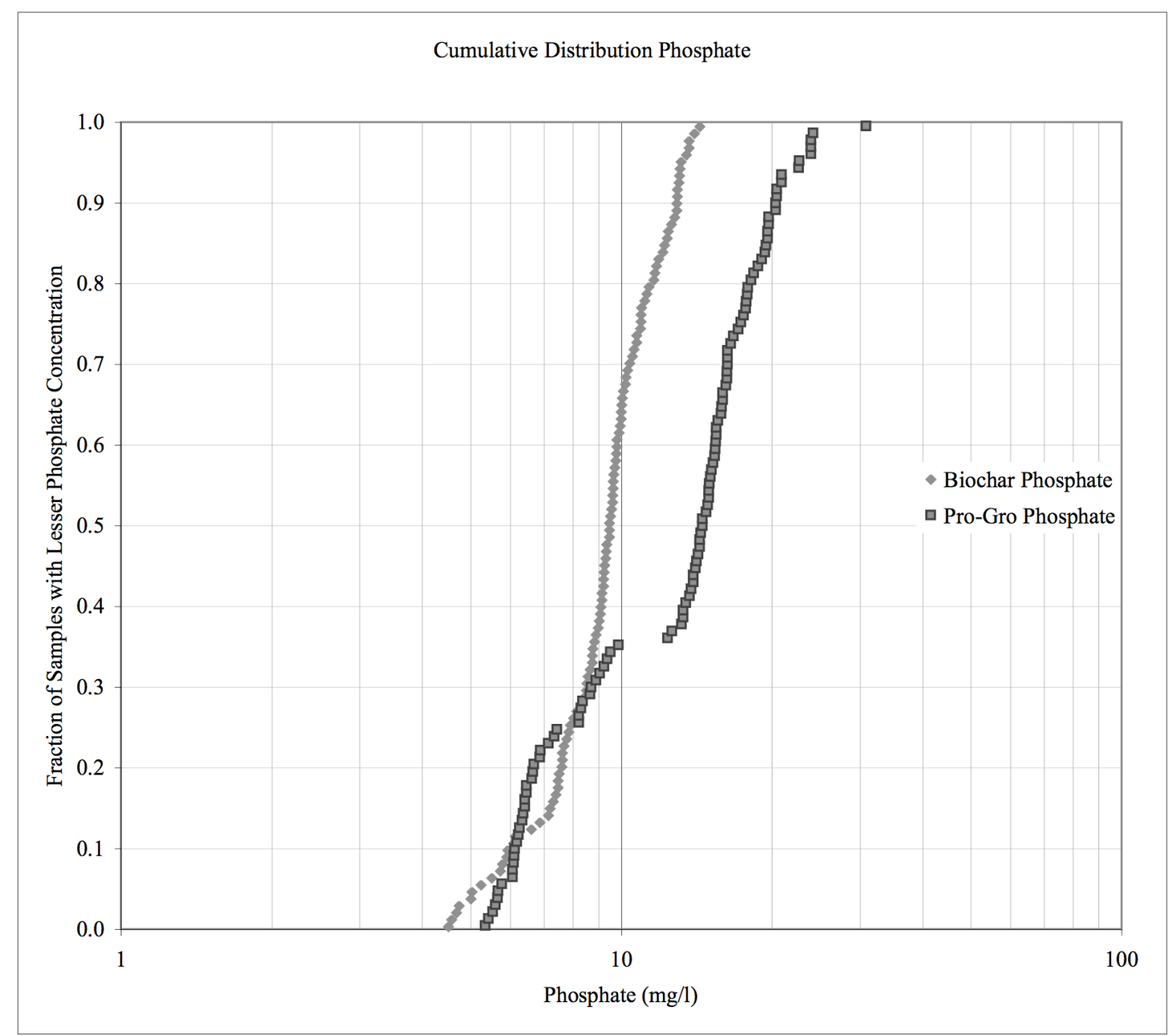

Figure 13: Cumulative distribution graph of rainfall runoff phosphate concentrations measured from all samples and fraction of phosphate released by each plant and soil type (inset graph).

The overlap of concentrations from both soil types below the 0.35 fraction of samples is of interest, even though this overlap does not signify lack of significant difference. A breakdown of fractions of phosphate samples sorted by soil and plant type (Figure 14), reveals that the overlap of the biochar-amended rainfall runoff phosphate concentrations by the Pro-Gro rainfall runoff phosphate concentrations seen 
below the 0.35 fraction of samples is strictly a result of the fraction of phosphate released by the Pro-Gro soil sedum trays. Almost all values from Pro-Gro sedum trays are all below the 0.35 fraction of samples. This overlap of concentrations suggests that when sedum is present Pro-Gro soil can potentially outperform biochar-amended soil in terms of phosphate retention. When sedum is not present, biochar-amended soil reduced the amount of phosphate present in the rainfall runoff by 5 to $7 \mathrm{mg} / \mathrm{l}$. The phosphate assay has an error of $\pm 0.6 \mathrm{mg} / \mathrm{l}$, and differences of 5 to $7 \mathrm{mg} / \mathrm{l}$ are well outside the range of error.
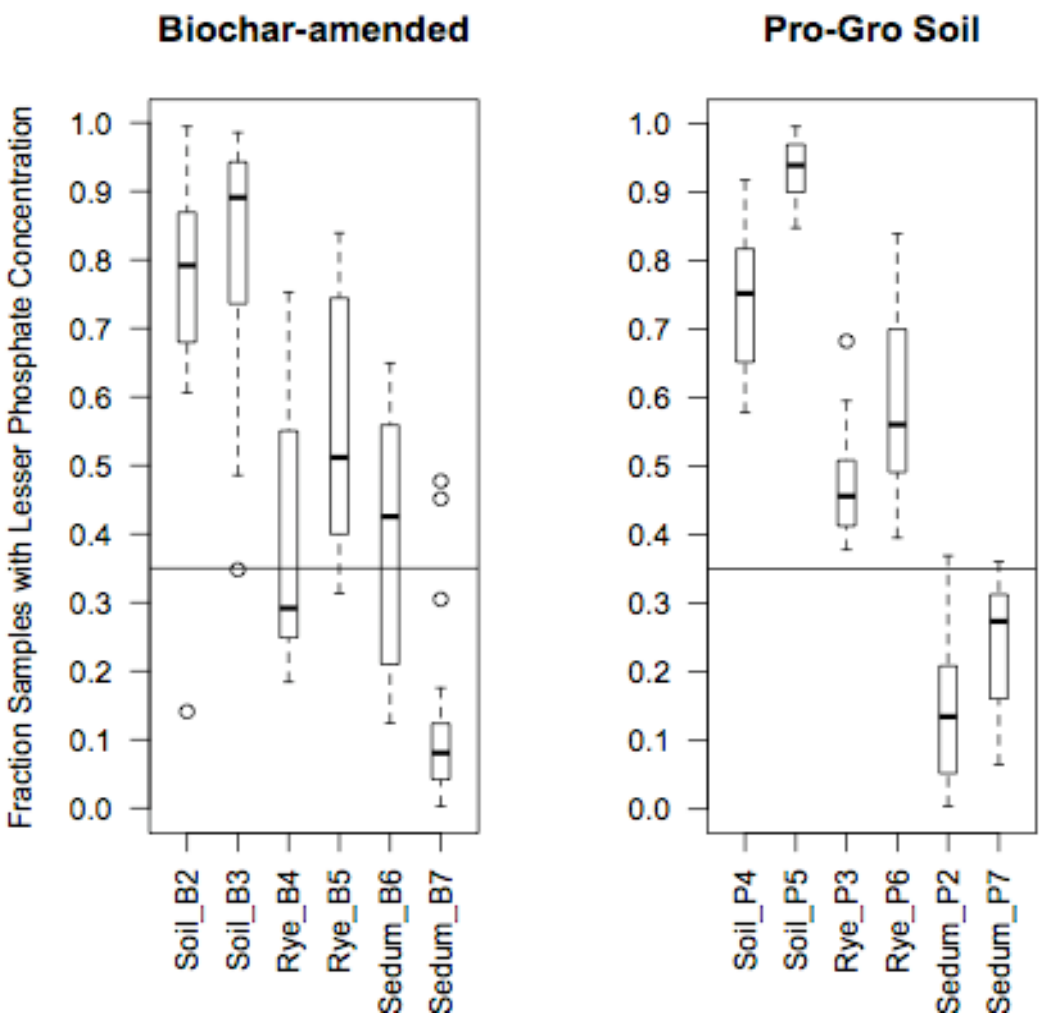

Figure 14: Boxplots showing breakdown of fractions of phosphate samples resulting from each soil type and plant type. Boxes show median, interquartiles at edges of box, and range of 1.5 times the interquartile range. Outliers are shown as circles. Note how both Pro-Gro sedum trays are below the 0.35 line. 


\section{Total Phosphorus}

Total phosphorus includes all elemental phosphorus including phosphorus in the form of phosphate. Total phosphorus results have a distribution resembling that of phosphate, as seen in Figure 15, with the exception of no overlap in measured concentrations. The total phosphorus results show that trays with biochar-amended soil released less total phosphorus than trays not containing biochar (KolmogorovSmirnov p-value $2.20 \mathrm{e}-16$ ). The total phosphorus assay uncertainty analysis yielded an error of $\pm 1.5 \mathrm{mg} / \mathrm{l}$ for total phosphorus concentrations. Therefore even at the point of least difference seen where the fraction of sample equals 0.17 , where biochar-amended rainfall runoff has a total phosphorus concentration of $7.7 \mathrm{mg} / 1$, and Pro-Gro rainfall runoff has a total phosphorus concentration of $9.3 \mathrm{mg} / \mathrm{l}$, the difference of $1.6 \mathrm{mg} / \mathrm{l}$ is still larger than the range of error. 


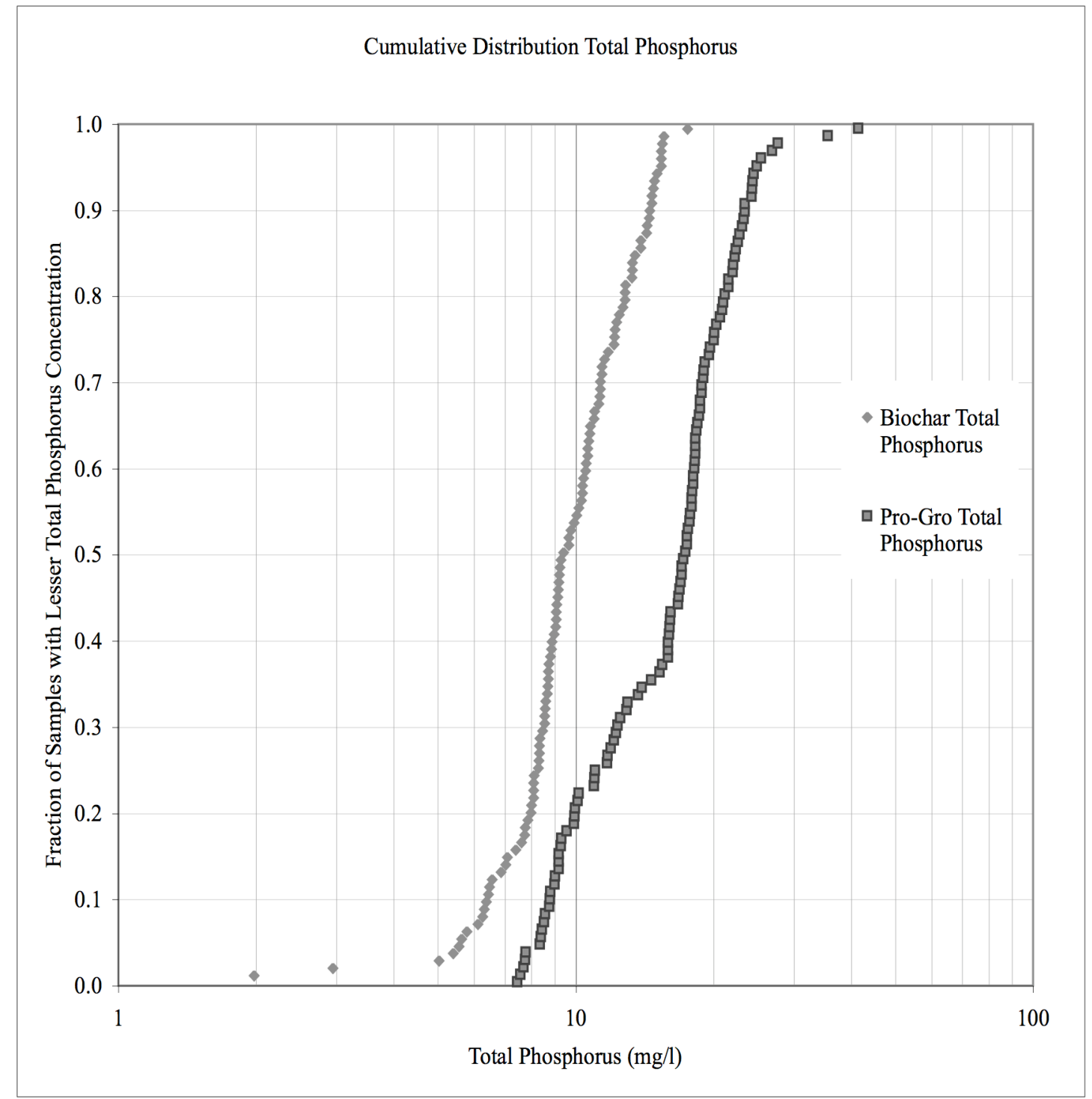

Figure 15: Cumulative distribution graph of rainfall runoff total phosphorus concentrations measured from all samples 
3.2 Rainfall, Rainfall Runoff Rates, and Collected Volume Error

\section{$\underline{\text { Rainfall Rates }}$}

Rainfall rates varied from experiment to experiment and from left and right tray positions in the testing unit GERTY due to inherent design of the rainfall simulator and imprecision of the pressure regulator on the water source tank. The average rainfall rate for each plant type ranged from 2.8 to $2.9 \mathrm{in} / \mathrm{hr}$, with standard deviations of $0.1 \mathrm{in} / \mathrm{hr}$, and coefficients of variation of 4 to $5 \%$, Table 3 . Rainfall rates are shown in Figure 16 with errors bars of one standard deviation. The average rainfall rate for each plant type was chosen as a representative curve and except for Figure 16 is plotted without error bars for visual clarity.

Table 3: Rainfall rates by run and by tray.

\begin{tabular}{|c|c|c|c|c|c|c|c|}
\hline & \multicolumn{7}{|c|}{ Soil-only: Rainfall rates (in/hr) } \\
\hline Rain Event & $\mathrm{P} 4$ & P5 & B2 & B3 & Average & $\begin{array}{c}\text { Standard } \\
\text { Deviation }\end{array}$ & $\begin{array}{l}\text { Coefficient } \\
\text { of Variation }\end{array}$ \\
\hline $\mathrm{A}$ & 2.9 & 2.7 & 2.9 & 2.7 & 2.8 & 0.1 & 4 \\
\hline $\mathrm{B}$ & 2.9 & 2.7 & 2.9 & 2.7 & 2.8 & 0.1 & 4 \\
\hline & \multicolumn{7}{|c|}{ Sedum: Rainfall rates (in/hr) } \\
\hline Rain Event & $\mathrm{P} 2$ & P7 & B6 & B7 & Average & $\begin{array}{c}\text { Standard } \\
\text { Deviation }\end{array}$ & $\begin{array}{l}\text { Coefficient } \\
\text { of Variation }\end{array}$ \\
\hline $\mathrm{A}$ & 2.9 & 2.7 & 2.9 & 2.7 & 2.8 & 0.1 & 4 \\
\hline $\mathrm{B}$ & 3.0 & 2.8 & 2.9 & 2.7 & 2.9 & 0.1 & 5 \\
\hline & \multicolumn{7}{|c|}{ Ryegrass: Rainfall rates (in/hr) } \\
\hline Rain Event & P3 & P6 & B4 & B5 & Average & $\begin{array}{l}\text { Standard } \\
\text { Deviation }\end{array}$ & $\begin{array}{l}\text { Coefficient } \\
\text { of Variation }\end{array}$ \\
\hline A & 2.8 & 3.0 & 2.9 & 2.7 & 2.9 & 0.1 & 5 \\
\hline $\mathrm{B}$ & 2.8 & 3.0 & 3.0 & 2.8 & 2.9 & 0.1 & 4 \\
\hline
\end{tabular}




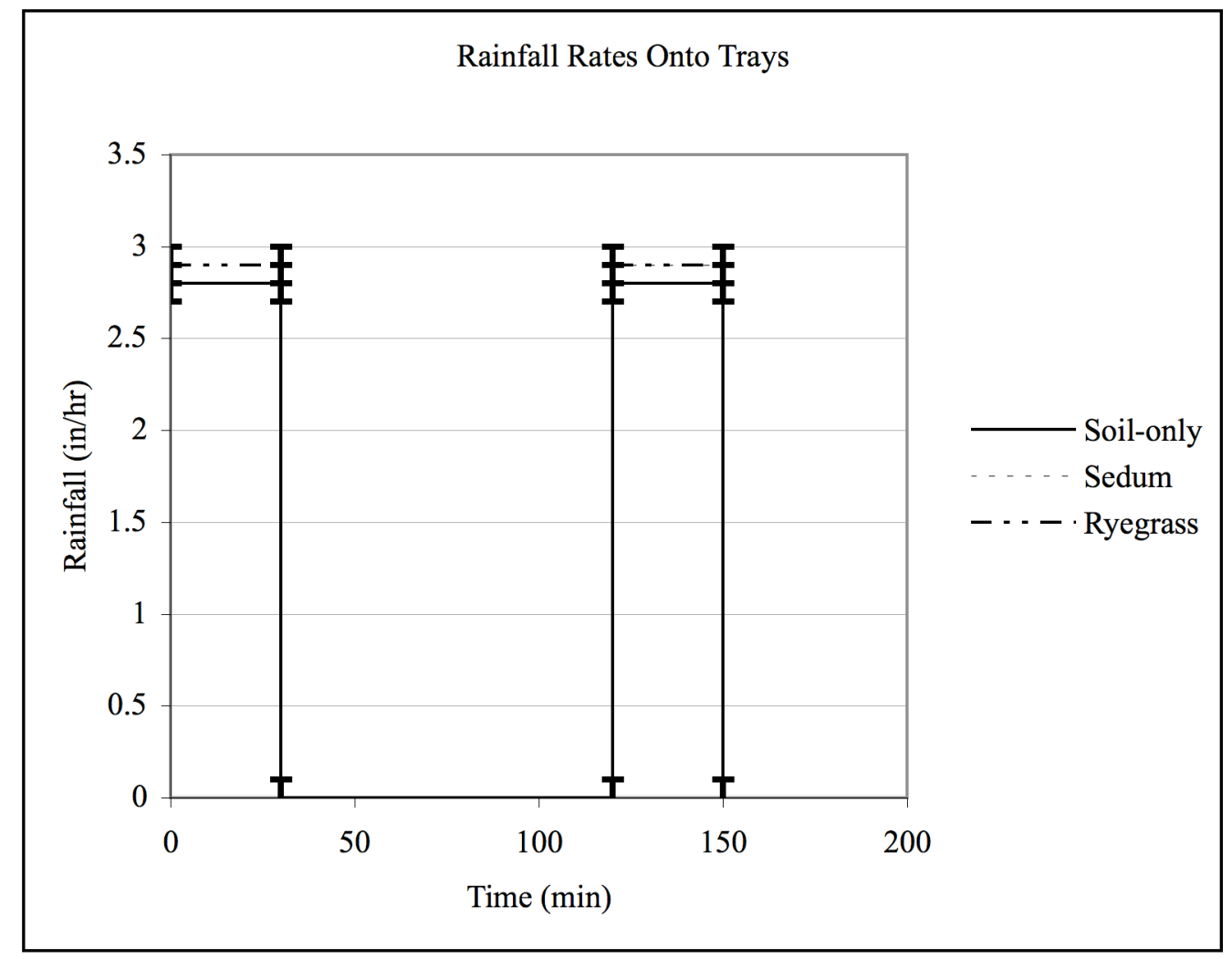

Figure 16: Average rainfall rates onto trays by run with error bars showing one standard deviation.

\section{$\underline{\text { Rainfall Runoff Rates }}$}

Rainfall runoff rates were calculated from the time stamp given each collected liter of rainfall runoff. Rainfall runoff rates determined for each liter of collected runoff are plotted in Figure 17. Rainfall runoff rates were impacted by both improperly sealed drain holes and timing errors during sample collection. 


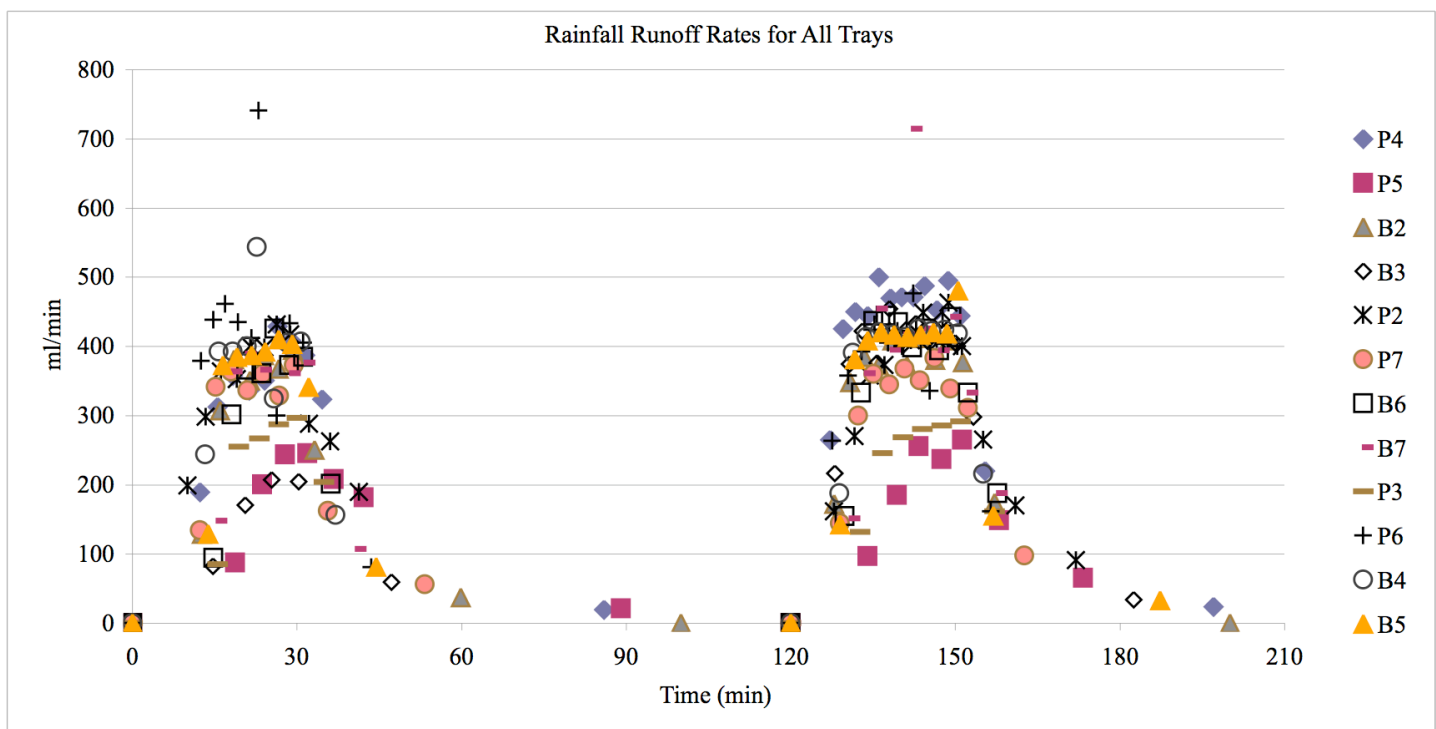

Figure 17: Rainfall runoff rates for each liter of collected runoff for all trays.

Two trays (P3 and P5) had failed seals and rainfall runoff escaped through other routes than the desired drain tube. The rainfall runoff data from these two trays as well as the three data points that were caused by incorrect time stamp collection were removed from the dataset. The remaining data was then used to generate a representative rainfall runoff curve by calculating the moving 5-point averages of the remaining rainfall rate data. The resulting moving 5-point averages are shown in Figure 18. The standard deviation was determined from the moving 5-point averages. Standard deviations ranged from 0.004 to $151 \mathrm{ml} / \mathrm{min}$, Figure 19 . When included in figures other than Figure 19, the representative rainfall runoff curve is plotted without error bars for visual clarity. 


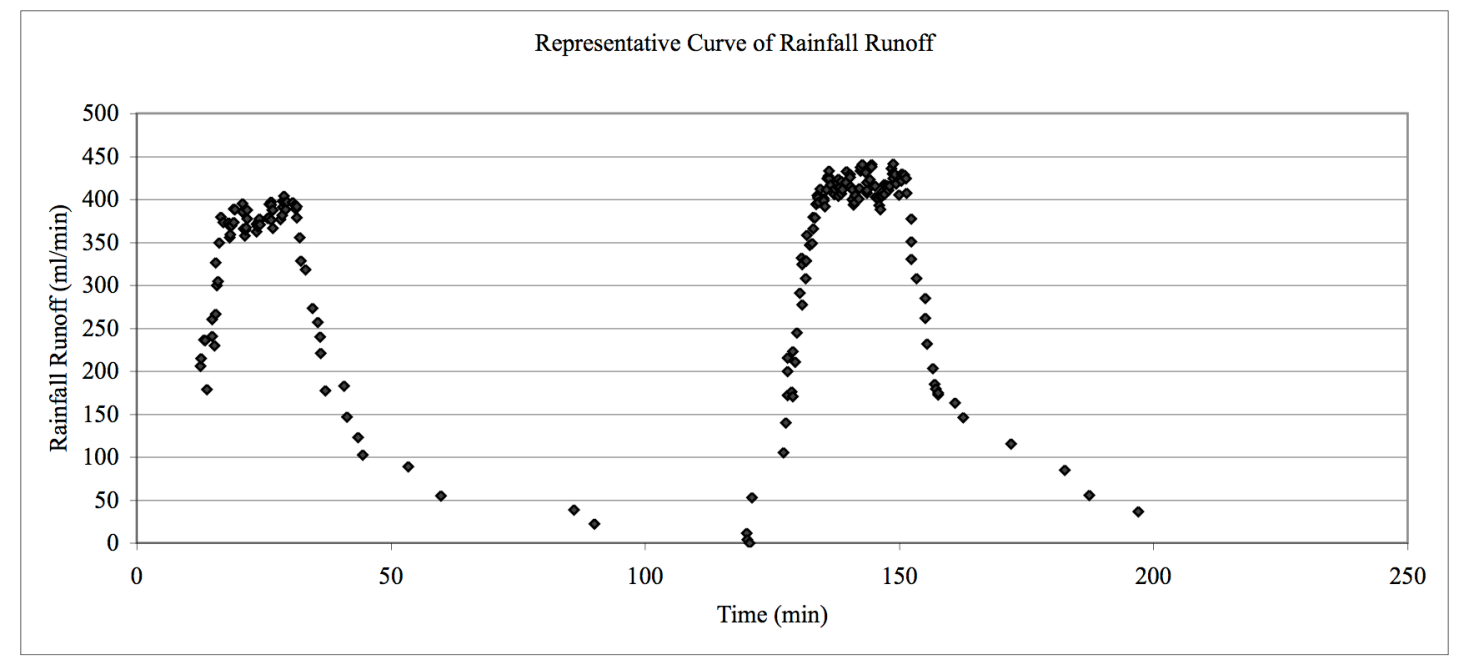

Figure 18: Final representative curve of rainfall runoff.

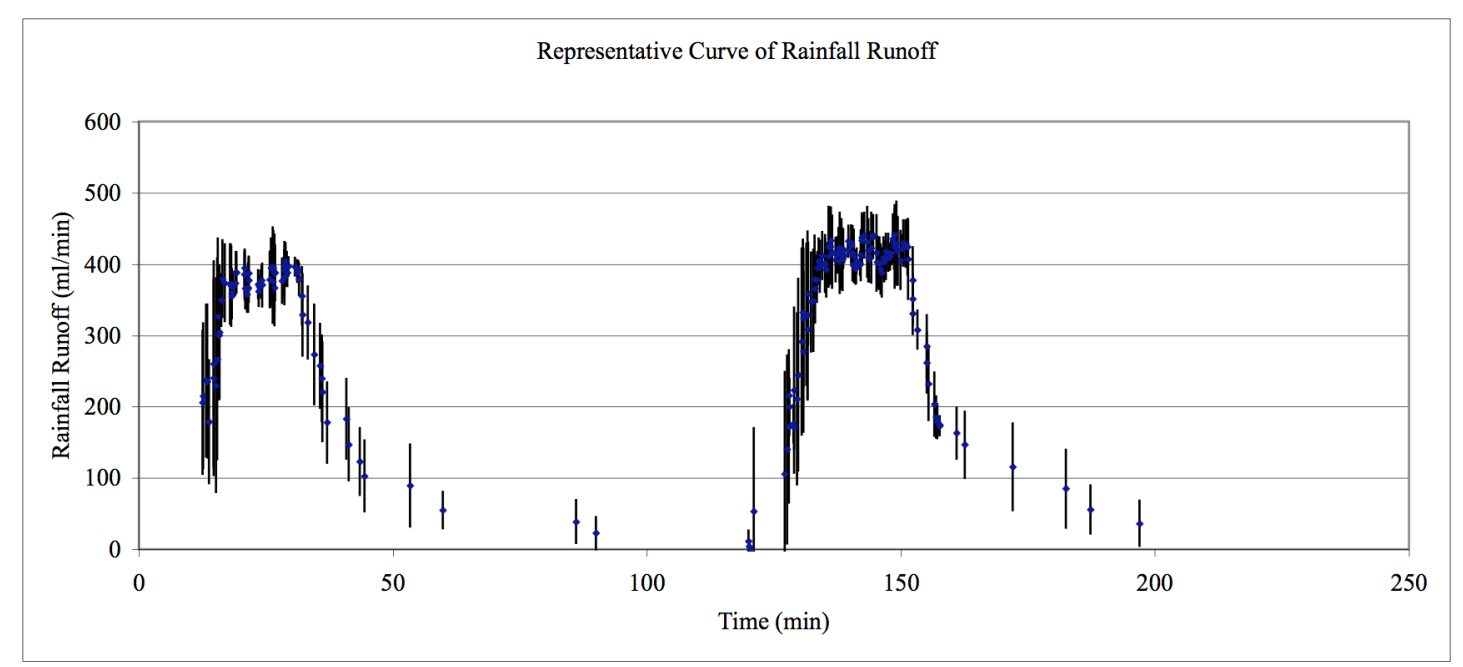

Figure 19: Representative rainfall runoff curve of 5-point moving averages with error bars showing standard deviations of each point.

\section{Collected Volume Error}

Propagation of error from both improperly sealed drain holes and timing errors throughout the volume measurements of rainfall onto the trays and rainfall runoff exiting the trays resulted in percent errors ranging from 2.5 to $23 \%$ as shown in Table 4. 
Table 4: Differences of rainfall runoff volumes and resulting percent error for all plants and each soil type.

\begin{tabular}{|c|c|c|c|c|c|c|c|}
\hline $\begin{array}{l}\text { Soil } \\
\text { type }\end{array}$ & Plant type & Run & $\begin{array}{l}\text { Weight } \\
\text { released } \\
\text { (lbs) }\end{array}$ & $\begin{array}{l}\text { Liters of } \\
\text { rainfall } \\
\text { runoff } \\
\text { determined } \\
\text { by weight }\end{array}$ & $\begin{array}{l}\text { Liters of } \\
\text { rainfall } \\
\text { runoff } \\
\text { determined } \\
\text { by } \\
\text { collection }\end{array}$ & $\begin{array}{c}\text { Percent } \\
\text { difference } \\
\text { between } \\
\text { weight } \\
\text { versus } \\
\text { collection }\end{array}$ & $\begin{array}{c}\text { Percent loss } \\
\text { of rainfall } \\
\text { runoff }\end{array}$ \\
\hline \multirow{4}{*}{ ProGro } & Soil Only & \multirow{4}{*}{ A } & 40.6 & 18.5 & 16.5 & 11.3 & 10.7 \\
\hline & Sedum & & 44.7 & 20.3 & 20.8 & 2.2 & -2.2 \\
\hline & Ryegrass & & 38.1 & 17.3 & 16.0 & 8.0 & 7.7 \\
\hline & Average & & 41.1 & 18.7 & & & \\
\hline \multirow{4}{*}{ Biochar } & Soil Only & \multirow{4}{*}{ A } & 40.0 & 18.2 & 14.8 & 20.3 & 18.5 \\
\hline & Sedum & & 39.7 & 18.0 & 17.3 & 3.9 & 3.9 \\
\hline & Ryegrass & & 38.1 & 17.3 & 19.4 & 11.3 & -12.0 \\
\hline & Average & & 39.2 & 17.8 & & & \\
\hline \multirow{4}{*}{ ProGro } & Soil Only & \multirow{4}{*}{ B } & 52.8 & 24.0 & 20.8 & 14.3 & 13.3 \\
\hline & Sedum & & 53.5 & 24.3 & 24.0 & 1.3 & 1.3 \\
\hline & Ryegrass & & 53.8 & 24.5 & 19.1 & 24.7 & 22.0 \\
\hline & Average & & 53.4 & 24.3 & & & \\
\hline \multirow{4}{*}{ Biochar } & Soil Only & \multirow{4}{*}{ B } & 48.5 & 22.0 & 23.8 & 7.5 & -7.8 \\
\hline & Sedum & & 48.4 & 22.0 & 22.7 & 3.2 & -3.3 \\
\hline & Ryegrass & & 53.6 & 24.4 & 24.2 & 0.9 & 0.9 \\
\hline & Average & & 50.2 & 22.8 & & & \\
\hline
\end{tabular}

\begin{tabular}{|c|c|c|}
\hline \multicolumn{3}{|c|}{ Root sum of square in \% } \\
\hline \multirow{3}{*}{ ProGro } & Soil Only & 17.1 \\
& Sedum & 2.5 \\
& Ryegrass & 23.3 \\
\hline \multirow{3}{*}{ Biochar } & Soil Only & 20.0 \\
& Sedum & 5.1 \\
& Ryegrass & 12.0 \\
\hline
\end{tabular}

\section{$\underline{3.3 \text { Run A Unsaturated versus Run B Saturated }}$}

Concentrations of nitrate, phosphate, total nitrogen, total phosphorus, and total organic carbon in the rainfall runoff from biochar-amended soil had noticeably 
different concentrations of nutrients in the runoff than Pro-Gro soil without biochar. Before the first rainfall event (Run A), soil moisture of all trays was estimated to be low and the soil was not saturated. After Run A, soil in each tray approached saturation, as evidenced by runoff obtained during the first rainfall event. Hence, concentration results for Run B rainfall water were representative of how the soil would perform when nearly saturated.

\section{Nitrate and Total Nitrogen}

Figure 20 shows measured concentrations of nitrate in the rainfall runoff as the experiments progressed. During the rainfall events nitrate concentrations decreased as the rate of runoff increased, with three exceptions (two soil-only trays [P4 and B3] and one sedum tray [P2]). All three exceptions occurred during Run A when the soil was of undetermined initial soil moisture and may be a result of transient flow conditions occurring within Run A. Rainfall events occurring on soil approaching saturation (Run B) showed steadily decreasing concentrations of nitrate as the rainfall event proceeded, which may indicate that the process of nitrate dissolving into the runoff water is rate-limited. That the dissolution of nitrate is rate-limited is evidenced by the increase of nitrate concentrations in samples taken after a rainfall event was stopped. The runoff water making up these samples had more contact time with the soil and more time for nitrate to dissolve into the soil porewater. The first few samples obtained from Run B consisted of water that had almost two hours of contact time with the soil and more time for nitrate to dissolve into the soil porewater before the soil porewater was displaced by incoming rainfall. 
The two Pro-Gro soil ryegrass trays had large discrepancies in nitrate concentrations as previously shown in Figure 11, and for this reason the nitrate results displaying concentration trends for these two trays (P3 and P6) are plotted on two different graphs in Figure 20. As previously discussed, the large discrepancy of nitrate concentrations between these two trays is suspected to be due to uneven mixing of the nitrogen sources in the starting Pro-Gro soil. Soil-only and sedum nitrate results tended toward having initial concentrations of Run B higher than ending concentrations of Run A, as occurred for 6 out of the 8 soil-only and sedum trays tested. Nitrate results from all four ryegrass trays had starting concentrations of Run B less than ending concentrations of Run A. This would point to the ryegrass planted in the trays actively performing nitrate uptake during the course of the experiment. 


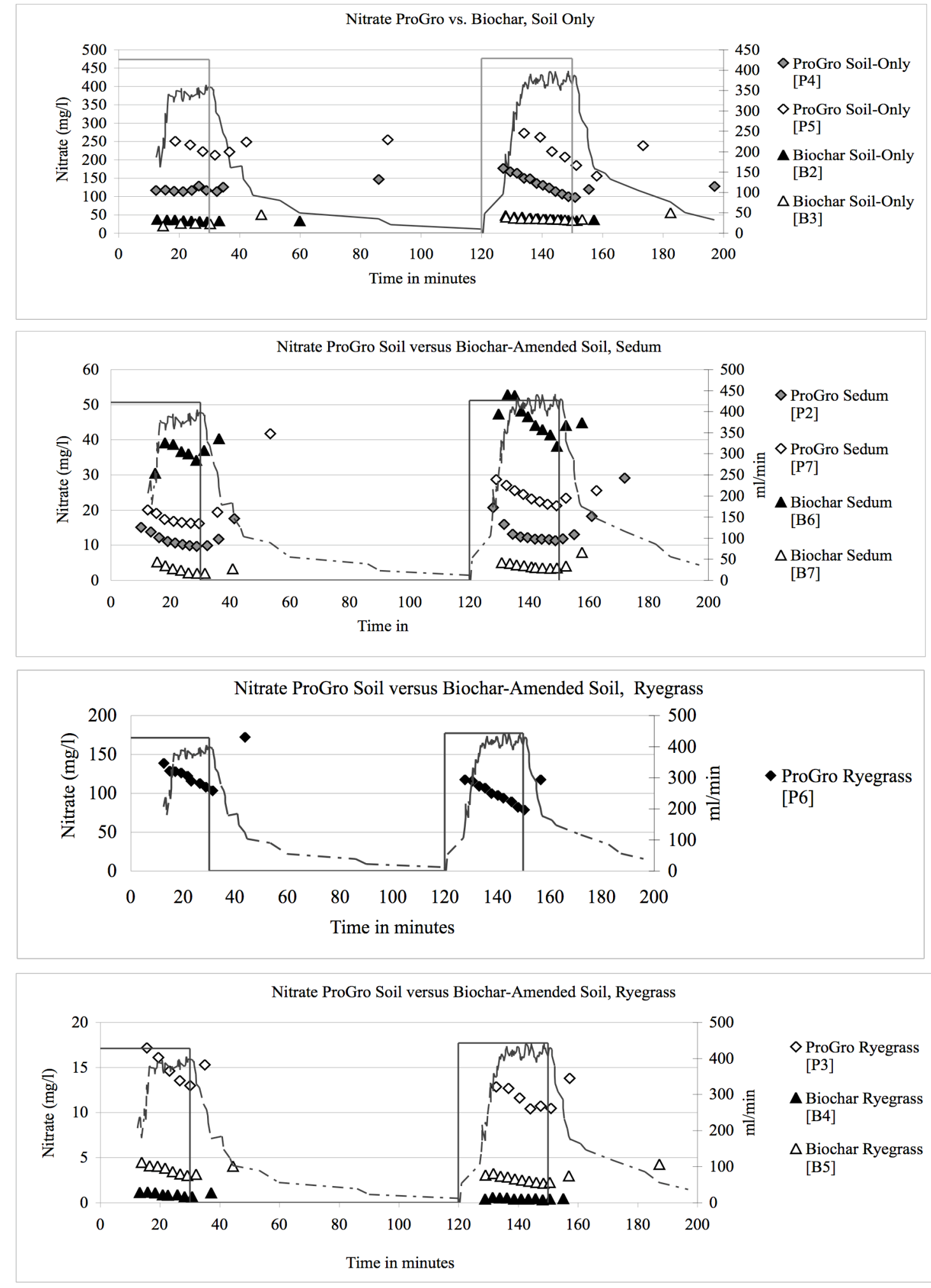

Figure 20: Nitrate concentrations of rainfall runoff. Solid lines are representative rainfall rates onto the trays and the dashed line is a representative runoff curve in $\mathrm{ml} / \mathrm{min}$. 
Total nitrogen results were only valid for ryegrass rainfall runoff samples due to all other samples being compromised by acid-fixing for sample preservation. As expected total nitrogen concentrations were consistently higher than nitrate concentrations for each collected rainfall runoff sample. Total nitrogen results showed the same trends as nitrate except for 3 out of the 4 ryegrass Run Bs having higher starting concentrations than ending Run A concentrations. As discussed previously, ryegrass appeared to actively perform nitrate uptake, resulting in starting concentrations of Run B being less than Run A. This difference from the ryegrass nitrate results may indicate that ryegrass performed uptake of nitrate-nitrogen during the two hours between Run A and Run B.

\section{Phosphate and Total Phosphorus}

Biochar-amended soil released lower concentrations of phosphate and total phosphorus than Pro-Gro soil, although the differences between the two soils were not as great as observed in the nitrate results. Figure 21 and Figure 22 show measured concentrations in the rainfall runoff of phosphate and total phosphorus, respectively, as the experiments progressed. Results from the first rainfall event, Run A, showed several trays released nearly constant concentrations of phosphate. This included all soil-only trays and one sedum biochar-amended tray (B6). The remaining trays showed decreasing concentrations of phosphate as rainfall runoff for Run A continued over time.

Rainfall events occurring on soil approaching saturation (Run B) showed steadily decreasing concentrations of phosphate and total phosphorus as the rainfall 
event proceeded, which may indicate that the process of phosphate and total phosphorus dissolving into the runoff water is rate-limited. That the dissolution of phosphate and total phosphorus is rate-limited is evidenced by the increase of phosphate and total phosphorus concentrations in samples taken after a rainfall event was stopped. The runoff water making up these samples had more contact time with the soil and more time for phosphate and total phosphorus to dissolve into the soil porewater. The first few samples obtained from Run B consisted of water that had almost two hours of contact time with the soil and more time for phosphate and total phosphorus to dissolve into the soil porewater before the soil porewater was displaced by incoming rainfall.

Trays planted with sedum released the smallest range of phosphate with concentrations between 4.5 and $12.6 \mathrm{mg} / \mathrm{l}$. Sedum appears to uptake or have a retention effect on phosphate and total phosphorus from both soil types. 


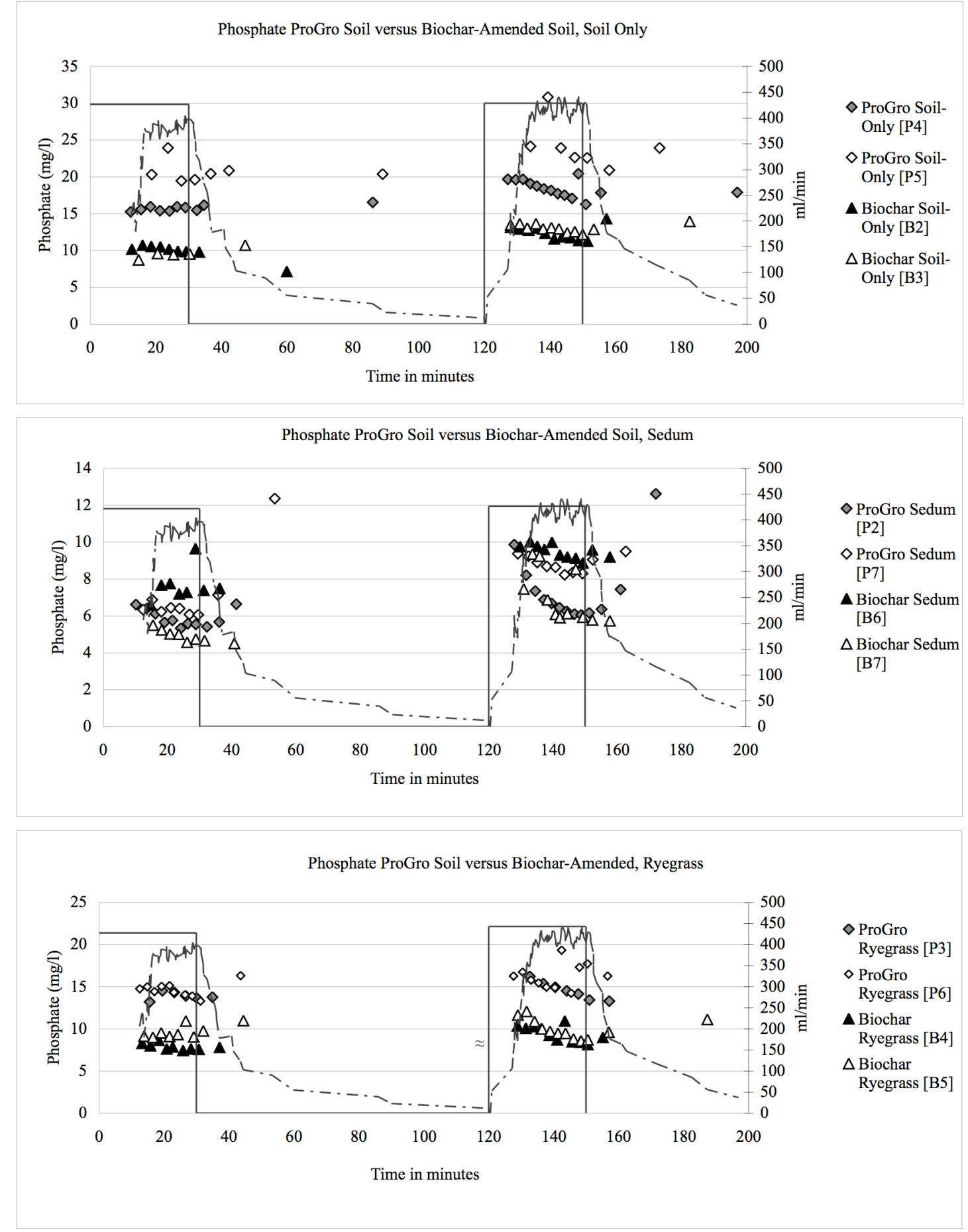

Figure 21: Phosphate concentrations of rainfall runoff. Solid lines are representative rainfall rates onto the trays and the dashed line is a representative runoff curve in $\mathrm{ml} / \mathrm{min}$. 

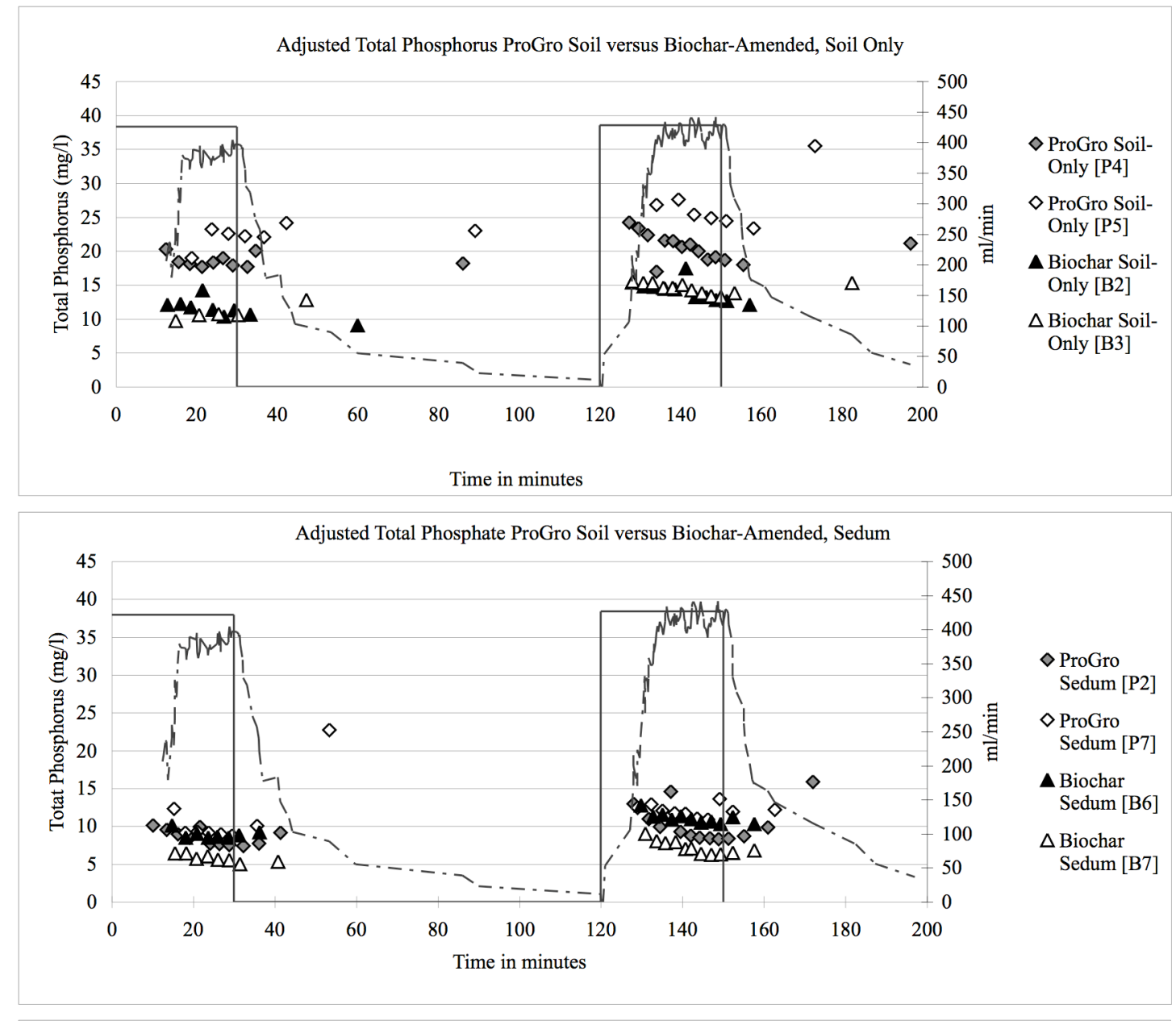

Total Phosphorus ProGro Soil versus Biochar-Amended, Ryegrass

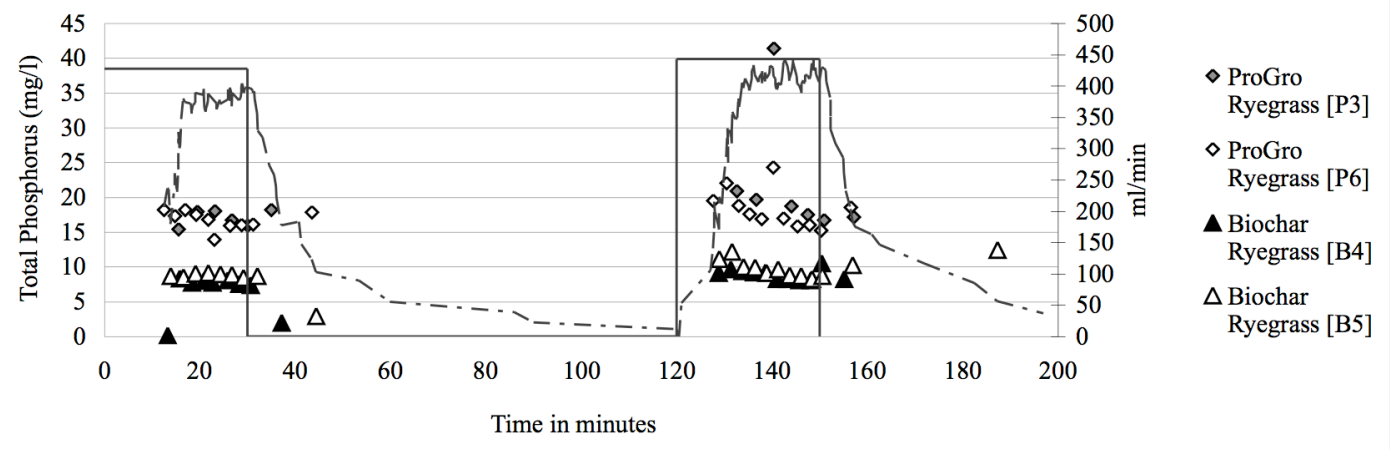

Figure 22: Adjusted total phosphorus and total phosphorus concentrations of rainfall runoff. Total phosphorus values were calculated from raw data to adjust for effects of acid-fixing the samples from sedum and soil-only trays. Solid lines are representative rainfall rates onto the trays and the dashed line is a representative runoff curve in $\mathrm{ml} / \mathrm{min}$. 


\section{Total Organic Carbon}

As shown in Figure 23, soil-only, sedum, and ryegrass trays, for both soil types, showed decreasing amounts of total organic carbon as the rainfall events occurred. For both unsaturated (Run A) and saturated (Run B) trials, concentrations of total organic carbon decreased as the rainfall events continued and increased as soon as the rainfall event stopped indicating that the process of total organic carbon entering the soil porewater is rate-limited. Similar to nitrogen and phosphorus, organic carbon concentrations decreased as each rainfall event continued and increased once a rainfall event was stopped.

Soil-only trays released the highest concentrations of total organic carbon. Ryegrass and sedum planted in Pro-Gro soil released equivalent concentrations of total organic carbon. Trays with biochar-amended soil released concentrations of total organic carbon ranging from 15 to $51 \mathrm{mg} / 1$ verses trays with Pro-Gro soil that released concentrations of total organic carbon ranging from 46 to $188 \mathrm{mg} / \mathrm{l}$. The higher concentrations of total organic carbon seen in the Pro-Gro rainfall runoff samples helps explain the differences in turbidity seen between the Pro-Gro and biocharamended rainfall runoff samples. 


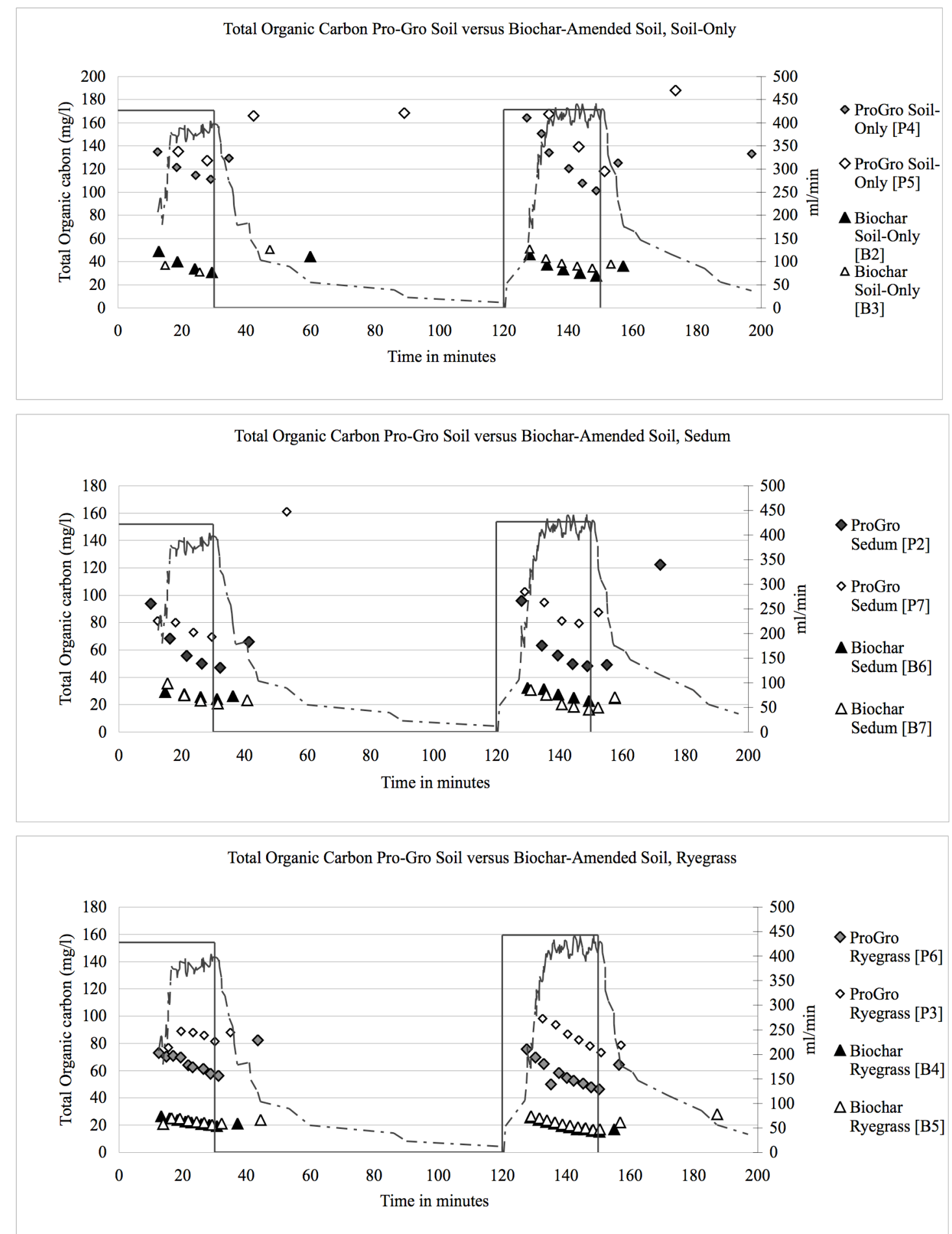

Figure 23: Total organic carbon concentrations of rainfall runoff. Solid lines are representative rainfall rates onto the trays and the dashed line is a representative runoff curve in $\mathrm{ml} / \mathrm{min}$. 
Inorganic Carbon

The presence of biochar in the soil had no impact on the amount of inorganic carbon entering the rainfall runoff. Inorganic carbon concentrations in the rainfall runoff of all experiments showed no significant difference between soil types. Inorganic carbon showed increasing or nearly constant concentrations during the Run A rainfall event (Figure 24). Inorganic carbon concentrations in the rainfall runoff do not appear to be related to total organic concentrations in the rainfall runoff as total organic carbon concentrations decreased during Run A, opposed to the increasing or nearly constant inorganic carbon concentrations observed during Run A. In contrast to Run A, all runoff samples from Run B showed decreasing inorganic carbon concentrations until the rainfall event was turned off, at which point inorganic carbon concentrations increased. Reasons for the decrease of inorganic carbon concentrations were not determinable from this experiment. Whether the decrease of inorganic carbon concentrations in the rainfall runoff was a result of flushing and therefore mass transfer into the rainfall runoff, or whether the decreasing concentrations signify possible rate-limitations of inorganic carbon in soil cannot be determined from this study. 

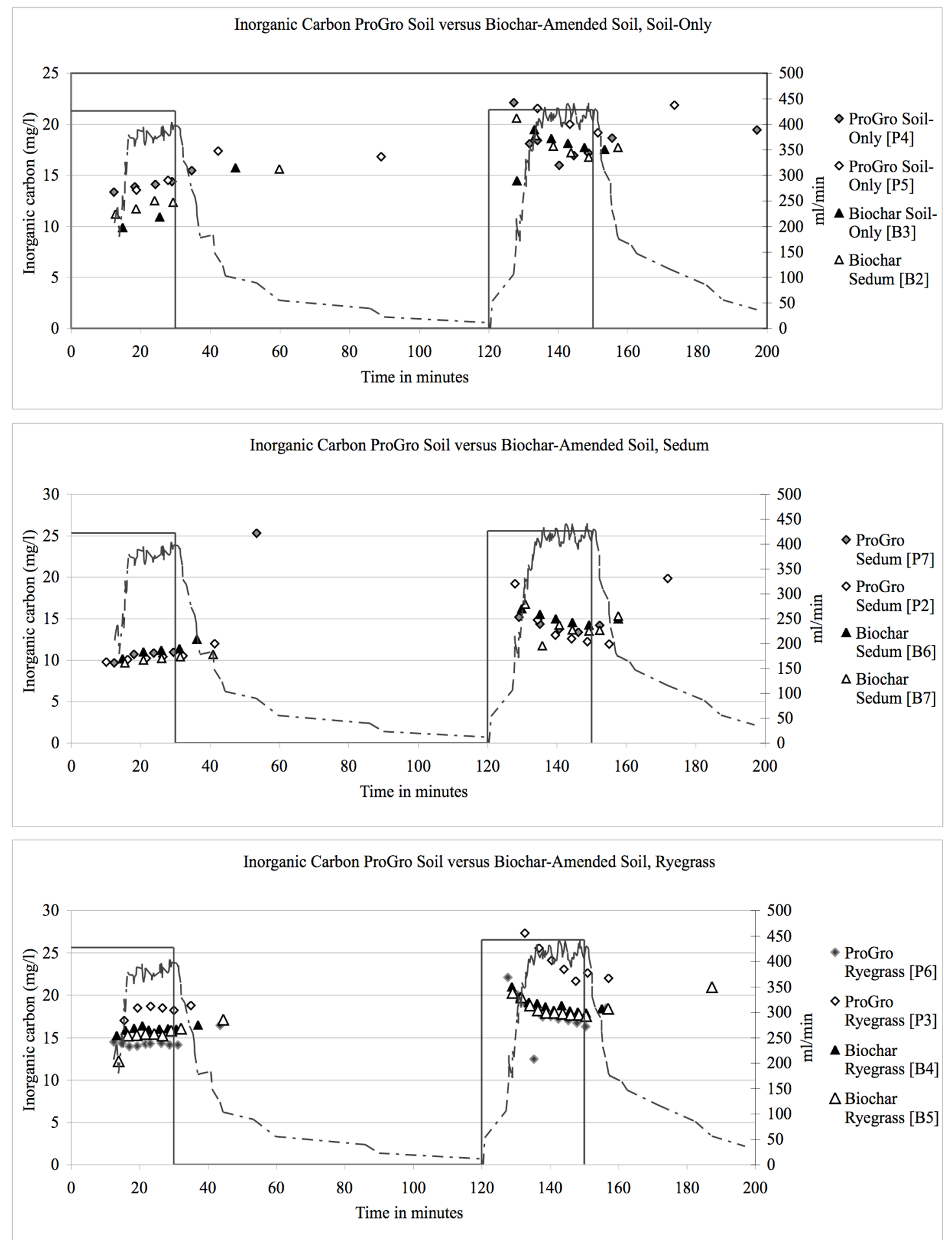

Figure 24: Inorganic carbon concentrations in rainfall runoff. Solid lines are representative rainfall rates onto the trays and the dashed line is a representative runoff curve in $\mathrm{ml} / \mathrm{min}$. 


\subsection{Retained Water by Both Soil Types}

Weight readings taken over the length of each experiment recorded the change of weight for each set of matching trays being tested. Soil moisture content of the trays was unknown when the rainfall event of Run A was started, causing the change of weight readings for the two different soils to be incomparable against each other with validity for the first rainfall event. The soil moisture content for each Run B, the second rainfall event, was close to saturation and the weight retention of water was comparable between the different Run Bs.

As shown in Table 5, the first rainfall event, Run A, from Pro-Gro and biocharamended soils retained 19.3 to $32.9 \%$ of rainfall and 29.5 to $32.5 \%$ of rainfall, respectively. For the second rainfall event, Run B, Pro-Gro soils retained 6.9 to $8.2 \%$ of rainfall and biochar-amended soil retained 8.5 to $14.5 \%$ of rainfall water. On average, biochar-amended soil retained more rainfall water then Pro-Gro soil, with bio-char amended soil retaining an average of $21.1 \%$ and Pro-Gro soil retaining an average of $17.8 \%$. When the soil approached saturation, the addition of $7 \%$ biochar resulted in a $4.4 \%$ increase of water retention. 
Table 5: Weight of retained water by Pro-Gro soil and biochar-amended trays during controlled rainfall events.

\begin{tabular}{|c|c|c|c|c|c|}
\hline Soil Type & Plant type & Run & $\begin{array}{c}\text { Weight of } \\
\text { Rainwater } \\
\text { added in (lbs) }\end{array}$ & $\begin{array}{c}\text { Weight of } \\
\text { Rainwater retained } \\
\text { in (lbs) }\end{array}$ & $\begin{array}{c}\% \text { of Rainfall } \\
\text { Added that } \\
\text { was Retained } \\
\text { by Soil } \\
\end{array}$ \\
\hline \multirow{4}{*}{ Pro-Gro } & Soil Only & \multirow{3}{*}{$A^{*}$} & 59.9 & 19.3 & 32.2 \\
\hline & Sedum & & 55.4 & 10.7 & 19.3 \\
\hline & Ryegrass & & 56.8 & 18.7 & 32.9 \\
\hline & Average & & 57.4 & 16.2 & 28.3 \\
\hline \multirow{4}{*}{$\begin{array}{l}\text { Biochar- } \\
\text { amended }\end{array}$} & Soil Only & \multirow{3}{*}{$\mathrm{A}^{*}$} & 56.7 & 16.7 & 29.5 \\
\hline & Sedum & & 56.4 & 16.7 & 29.6 \\
\hline & Ryegrass & & 56.4 & 18.3 & 32.5 \\
\hline & Average & & 56.5 & 17.2 & 30.5 \\
\hline \multirow{4}{*}{ Pro-Gro } & Soil Only & \multirow{4}{*}{ B } & 56.7 & 3.9 & 6.9 \\
\hline & Sedum & & 57.6 & 4.1 & 7.1 \\
\hline & Ryegrass & & 58.6 & 4.8 & 8.2 \\
\hline & Average & & 57.6 & 4.3 & 7.4 \\
\hline \multirow{4}{*}{$\begin{array}{l}\text { Biochar- } \\
\text { amended }\end{array}$} & Soil Only & \multirow{3}{*}{ B } & 56.7 & 8.2 & 14.5 \\
\hline & Sedum & & 55.4 & 7.0 & 12.6 \\
\hline & Ryegrass & & 58.6 & 5.0 & 8.5 \\
\hline & Average & & 56.9 & 6.7 & 11.8 \\
\hline Soil Type & Plant type & & $\begin{array}{c}\text { Total Weight } \\
\text { of Rainwater } \\
\text { added (lbs) }\end{array}$ & $\begin{array}{l}\text { Total Weight of } \\
\text { Rainwater retained } \\
\text { in (lbs) }\end{array}$ & \\
\hline \multirow{4}{*}{ Pro-Gro } & Soil Only & & 116.6 & 23.2 & 19.9 \\
\hline & Sedum & & 113.0 & 14.8 & 13.1 \\
\hline & Ryegrass & & 115.4 & 23.5 & 20.4 \\
\hline & Average & & 115.0 & 20.5 & 17.8 \\
\hline \multirow{4}{*}{$\begin{array}{l}\text { Biochar- } \\
\text { amended }\end{array}$} & Soil Only & & 113.4 & 24.9 & 22.0 \\
\hline & Sedum & & 111.7 & 23.7 & 21.2 \\
\hline & Ryegrass & & 115.0 & 23.3 & 20.3 \\
\hline & Average & & 113.4 & 24.0 & 21.1 \\
\hline
\end{tabular}

* Starting soil moisture was undetermined for these runs 
3.5 Percent Mass Recovery

Mass of each nutrient collected in the rainfall runoff was calculated using the trapezoid rule to compare the nutrient retention performance of biochar-amended soil to Pro-Gro soil. Percent mass recovery and total quantities of recovery mass where both evaluated. To compare percent mass recoveries, mass of a nutrient as measured in the Pro-Gro soil-only effluent was considered the maximum amount of a nutrient that would be present in the rainfall runoff under the experiment conditions. Therefore, the average of the total mass recovered from the Pro-Gro soil-only trays was calculated and considered the 'control'. The control mass value was then used to scale all mass results obtained from the other trays, allowing comparisons of the masses of each measured nutrient in the rainfall runoff. Percent mass recoveries for each soil type and plant type are summarized in Table 6.

Table 6: Percent mass of nutrient recovered as scaled by total accumulated nutrient mass recovered from Pro-Gro soil-only trays.

\begin{tabular}{|c|c|c|c|c|c|c|}
\hline Plant Type & Tray & $\begin{array}{c}\text { Nitarte } \\
(\%)\end{array}$ & $\begin{array}{c}\text { Phosphate } \\
(\%)\end{array}$ & $\begin{array}{c}\text { Total } \\
\text { Phosphorus } \\
(\%)\end{array}$ & $\begin{array}{c}\text { Total } \\
\text { Organic } \\
\text { Carbon (\%) }\end{array}$ & $\begin{array}{c}\text { Inorganic } \\
\text { Carbon (\%) }\end{array}$ \\
\hline \multirow{4}{*}{ Soil Only } & ProGro [P4] & set to 100 & set to 100 & set to 100 & set to 100 & set to 100 \\
\hline & ProGro [P5] & set to 100 & set to 100 & set to 100 & set to 100 & set to 100 \\
\hline & Biochar [B2] & 24 & 62 & 64 & 28 & 94 \\
\hline & Biochar [B3] & 20 & 56 & 56 & 24 & 77 \\
\hline \multirow{4}{*}{ Sedum } & ProGro [P2] & 10 & 44 & 56 & 58 & 91 \\
\hline & ProGro [P7] & 14 & 42 & 52 & 62 & 74 \\
\hline & Biochar [B6] & 26 & 46 & 48 & 20 & 77 \\
\hline & Biochar [B7] & 2 & 32 & 31 & 17 & 70 \\
\hline \multirow{4}{*}{ Ryegrass } & ProGro [P3] & 5 & 50 & 62 & 41 & 81 \\
\hline & ProGro [P6] & 76 & 90 & 91 & 50 & 102 \\
\hline & Biochar [B4] & 0.4 & 48 & 39 & 16 & 106 \\
\hline & Biochar [B5] & 2 & 57 & 47 & 18 & 109 \\
\hline
\end{tabular}


$\underline{\text { Nitrate }}$

Mass of nitrate released into the rainfall runoff showed a large difference between the two soil types for the soil-only trays. Percent mass recovery measurements of nitrate of biochar-amended trays showed that the biochar-amended soil-only trays released $20 \%$ to $24 \%$ of the average mass of nitrate released by the control trays (Figure 25). The two biochar-amended ryegrass trays released $0.4 \%$ and $2 \%$ of the mass of nitrate compared to the $5 \%$ and $76 \%$ of mass of nitrate released by the Pro-Gro soil ryegrass trays. One Pro-Gro soil ryegrass tray (P6) released unexpectedly high levels on nitrate and the matching Pro-Gro ryegrass tray (P3) released much lower masses of nitrate. Even with the large range of mass of nitrate being released from these two trays, the biochar-amended ryegrass trays still released less nitrate by mass than the Pro-Gro soil trays. Nitrate released by trays planted with sedum had the least differences between the two soil types, with Pro-Gro soil sedum trays releasing $10 \%$ and $14 \%$ of the control mass, and biochar-amended sedum trays releasing $2 \%$ and $26 \%$ of the control mass. 

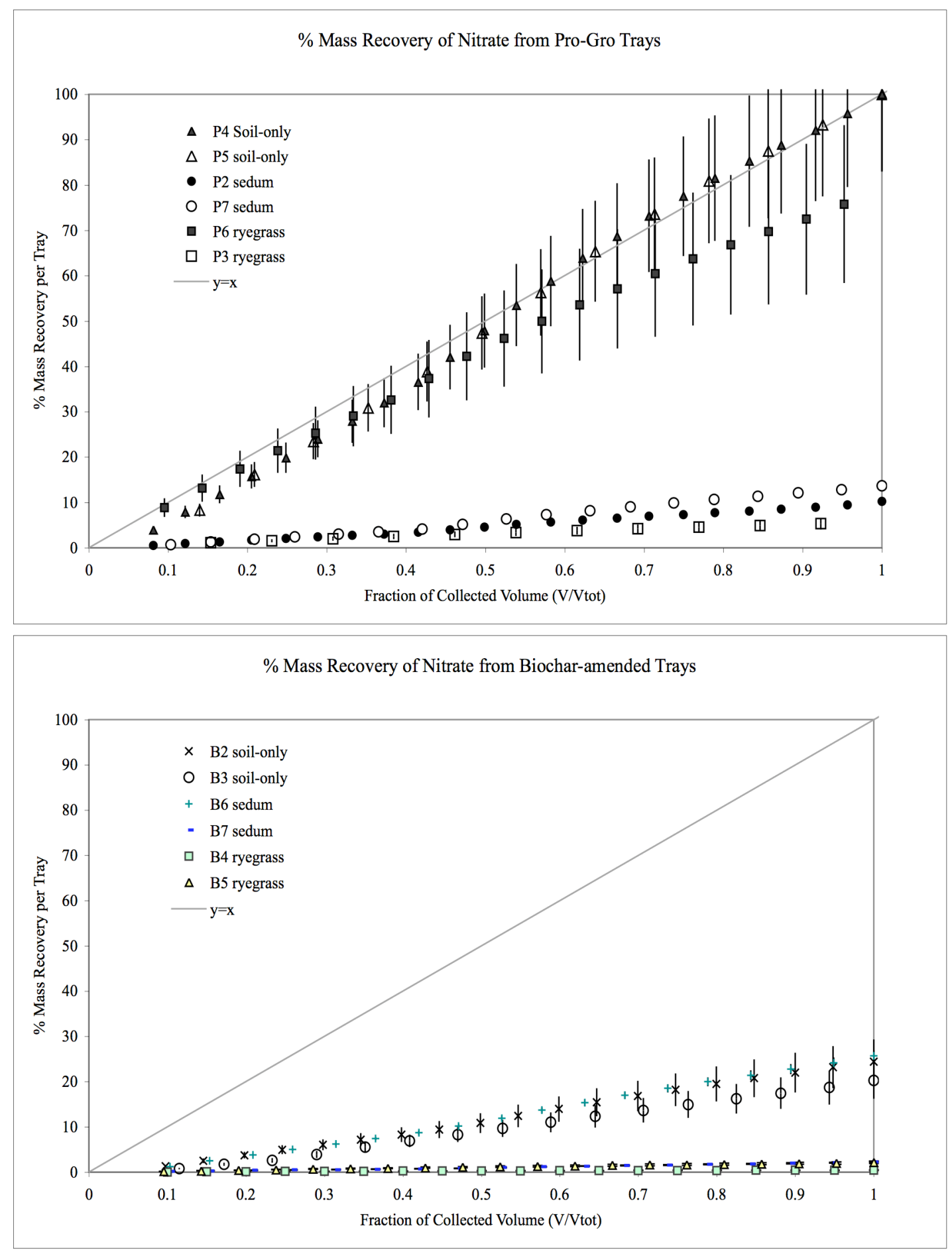

Figure 25: Percent mass recovery of nitrate from Pro-Gro and biochar-amended trays with error bars and $y=x$ line for visual reference. Average total mass of nitrate recovered from Pro-Gro soil-only trays was used to scale mass values from all other trays. 


\section{Phosphate and Total Phosphorus}

Biochar-amended soil released $56 \%$ and $66 \%$ of the total mass of phosphate released by the control Pro-Gro soil-only trays (Figure 26). The large difference of phosphate mass released by the two soil types was not seen in the trays containing plants. Both trays with ryegrass and sedum released overlapping ranges of phosphate into the rainfall runoff water. Pro-Gro soil ryegrass trays released accumulated masses of phosphate that equaled $50 \%$ and $90 \%$ of the phosphate released by the control. Biochar-amended ryegrass trays released $48 \%$ and $57 \%$ of the mass of phosphate released by the control trays. Mass of phosphate recovered in the rainfall runoff of trays planted with sedum revealed small differences between the two soil types. Biochar-amended trays planted with sedum released $32 \%$ and $45 \%$ of the total averaged phosphate released by the control and the Pro-Gro soil trays planted with sedum released $42 \%$ and $44 \%$ of the phosphate released by the control trays. The overlapping ranges of released mass of phosphate by the trays planted with sedum for both soil types may indicate sedum has a greater effect on the release of phosphate into rainfall runoff than the addition of $7 \%$ biochar as a soil amendment.

All biochar-amended trays released less total phosphorus into the rainfall runoff than Pro-Gro trays of matching plant type (Figure 27). Differences in the mass of total phosphorus were small for trays with plants, and larger for the soil-only trays, where biochar-amended soil-only trays released $56 \%$ and $64 \%$ of the control Pro-Gro soil-only trays. 

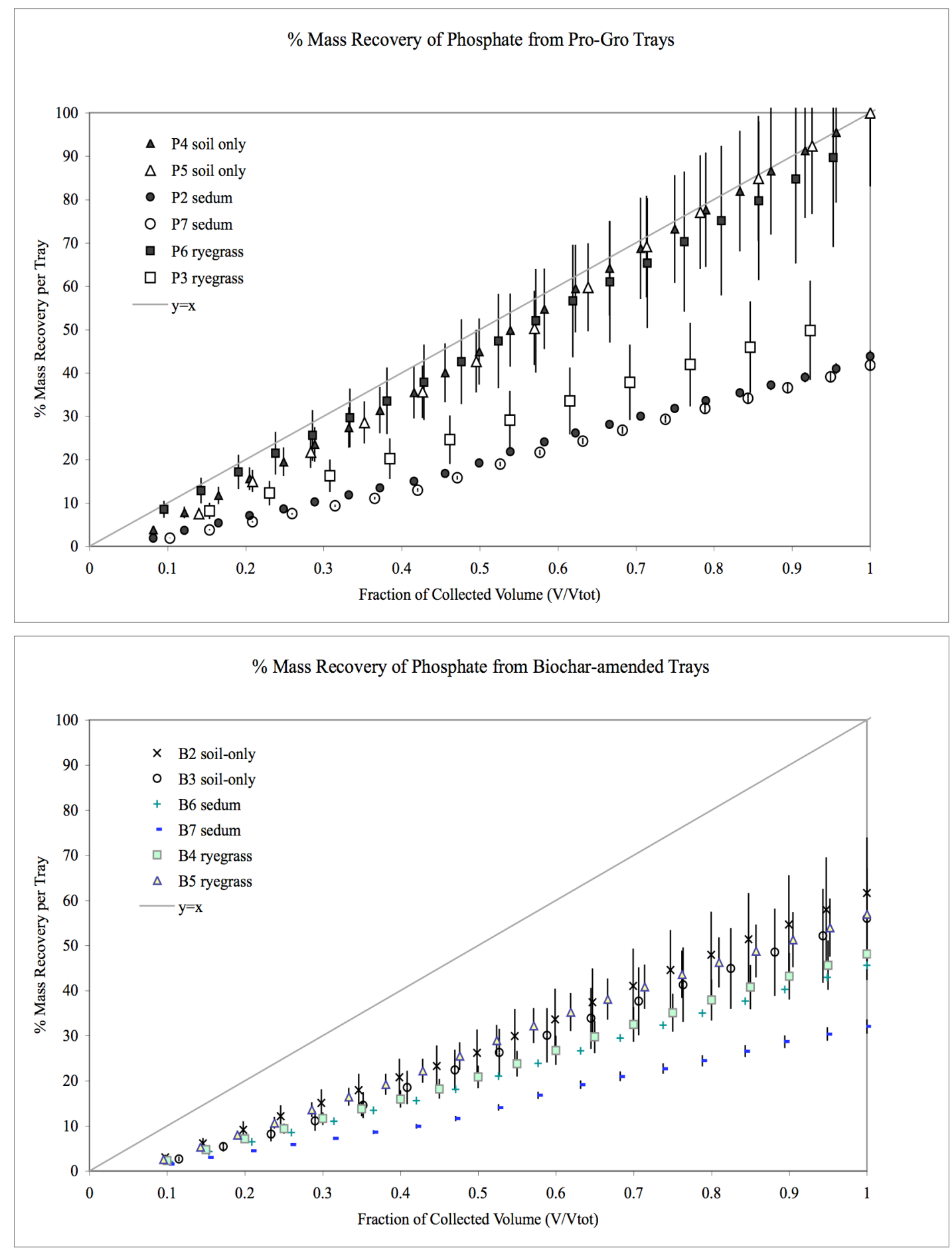

Figure 26: Percent mass recovery of phosphate from Pro-Gro and biochar-amended trays with error bars $\mathrm{y}=\mathrm{x}$ line for visual reference. Average total mass of phosphate recovered from Pro-Gro soil-only trays was used to scale mass values from all other trays. 

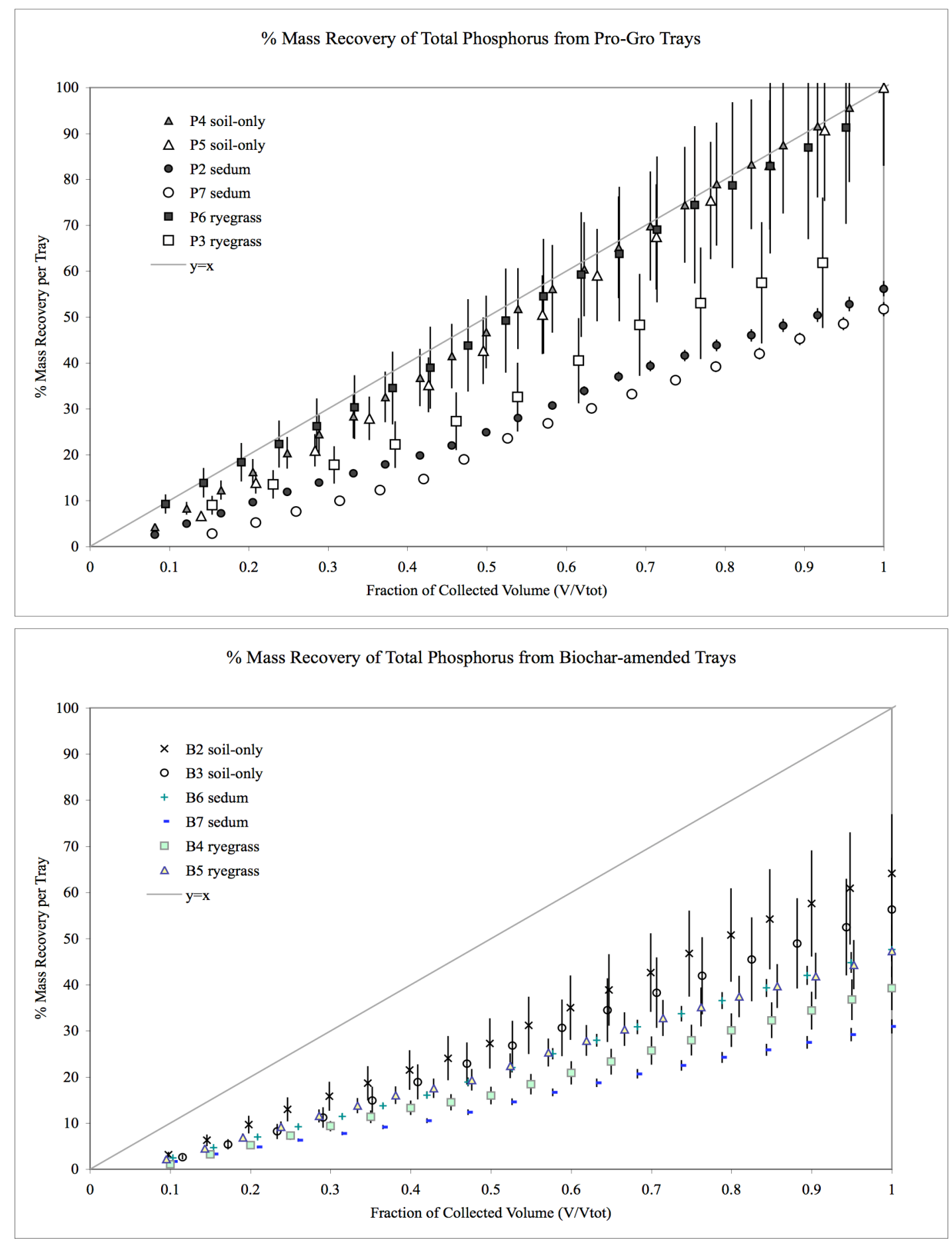

Figure 27: Percent mass recovery of total phosphorus from Pro-Gro and biocharamended trays with error bars $\mathrm{y}=\mathrm{x}$ line for visual reference. Average total mass of total phosphorus recovered from Pro-Gro soil-only trays was used to scale mass values from all other trays. 


\section{$\underline{\text { Total Organic Carbon and Inorganic Carbon }}$}

Biochar-amended soil showed dramatic reductions of total organic carbon mass recovered in the rainfall runoff (Figure 28). Large reductions of mass of total organic carbon in the biochar-amended rainfall runoff were observed regardless of plant type. Biochar-amended soils with and without plants released total organic carbon masses ranging from $16 \%$ to $28 \%$ of averaged mass released by the Pro-Gro soil-only control, compared to Pro-Gro soil trays that released $41 \%$ to $62 \%$ of the total organic carbon released by the control. The large difference of total organic carbon present in the Pro-Gro soil trays with plants leads to the interpretation that the plants have a lessoning effect on the amount of total organic carbon released into the rainfall runoff.

Mass recovery of inorganic carbon showed little difference between the ProGro soil and biochar-amended soil (Figure 29). Inorganic carbon recovery from biochar-amended soil rainfall runoff ranged from $70 \%$ to $109 \%$ of the Pro-Gro soilonly control, while Pro-Gro soils with plants ranged from $74 \%$ to $102 \%$ of the ProGro soil-only control. 

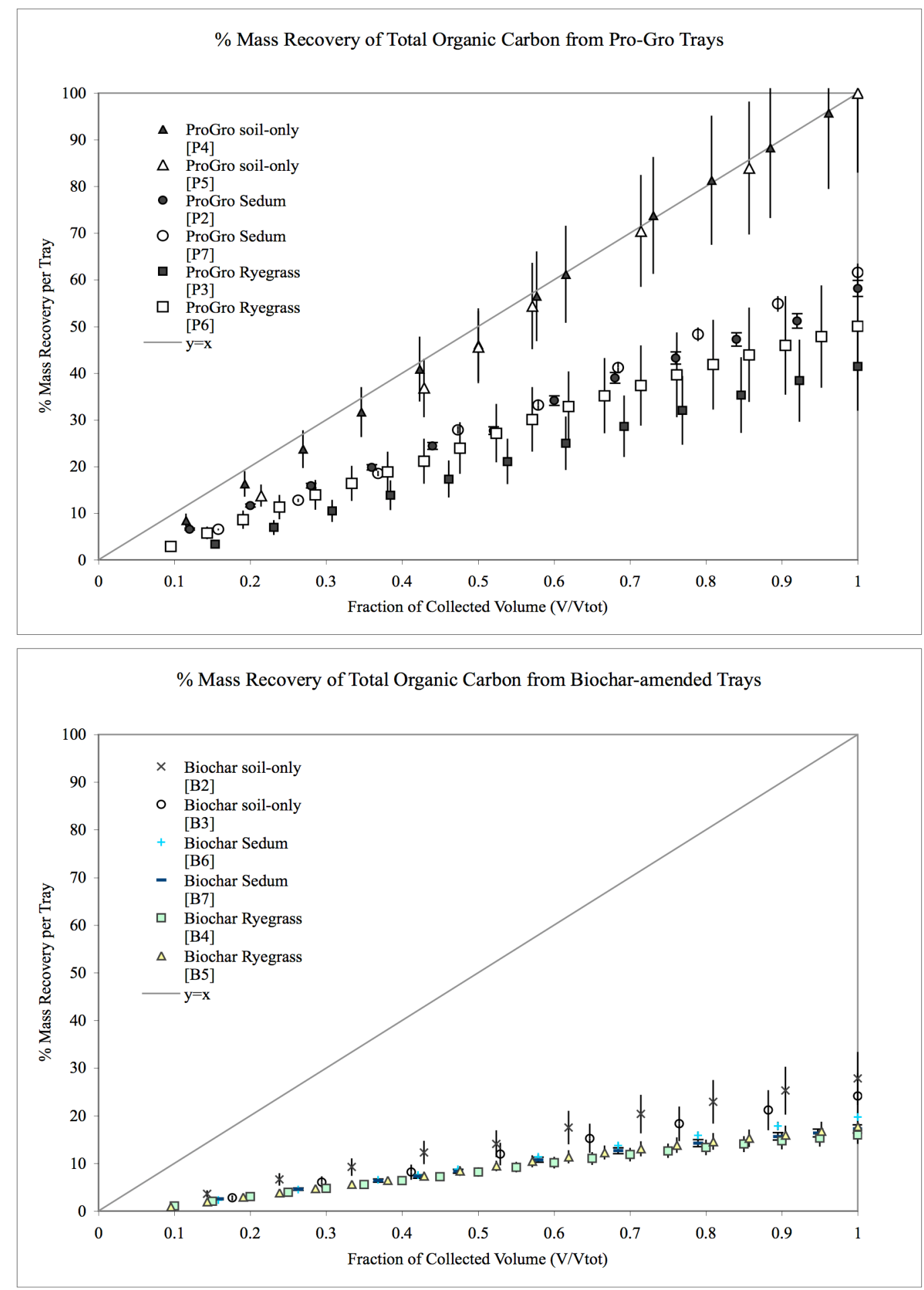

Figure 28: Percent mass recovery of total organic carbon from Pro-Gro and biocharamended trays with error bars $y=x$ line for visual reference. Average total mass of total organic carbon recovered from Pro-Gro soil-only trays was used to scale mass values from all other trays. 

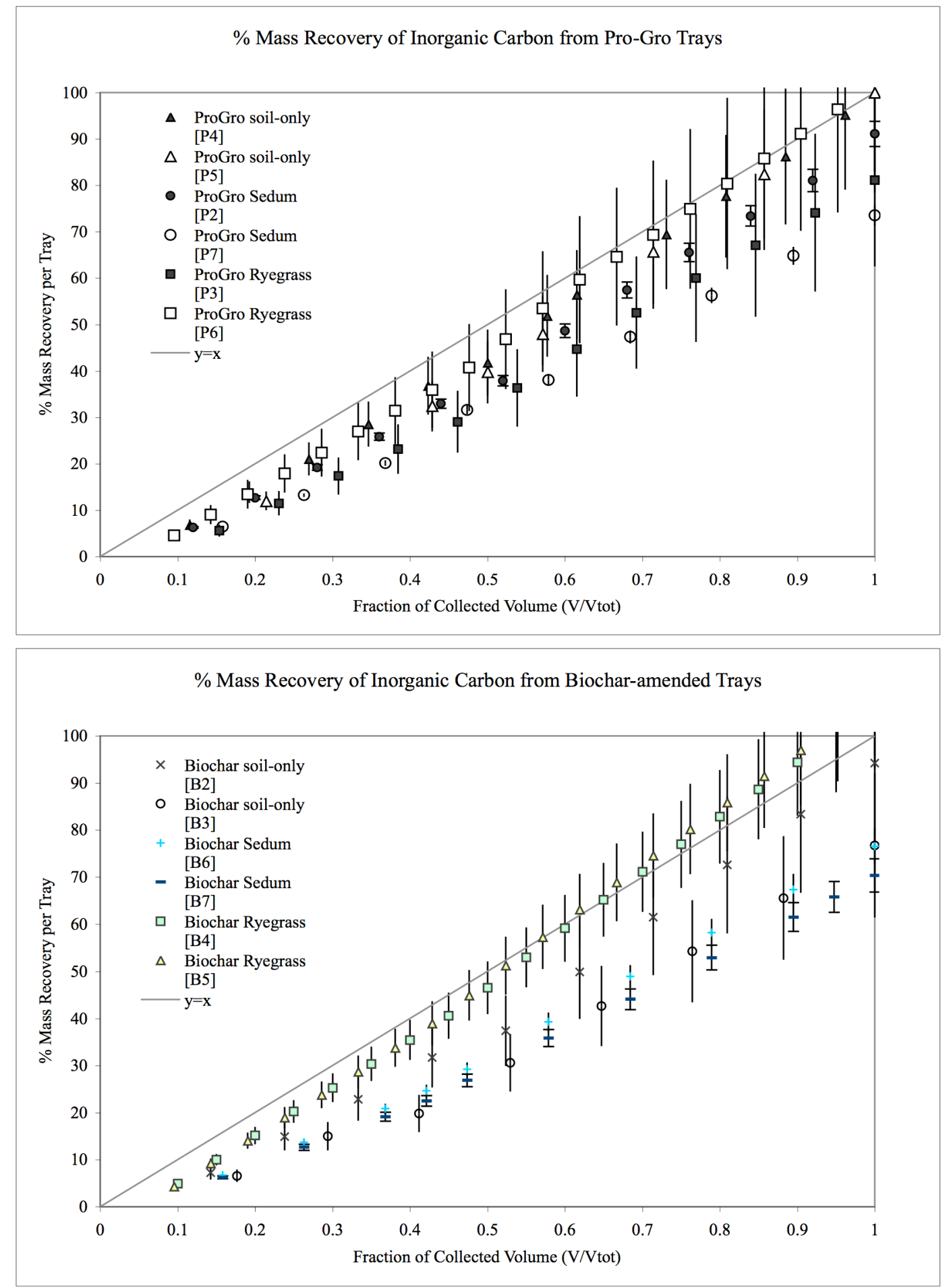

Figure 29: Percent mass recovery of inorganic carbon from Pro-Gro and biocharamended trays with error bars $\mathrm{y}=\mathrm{x}$ line for visual reference. Average total mass of inorganic carbon recovered from Pro-Gro soil-only trays was used to scale mass values from all other trays. 


\subsection{Total Mass Released into Rainfall Runoff}

Nitrate and Phosphate

Examination of total mass of measured nutrients released into the rainfall runoff, summarized in Table 7, and shown in Figures 30 and 31, reveals trays containing biochar-amended soil decreased the total mass of nitrogen, phosphorus, and total organic carbon in the rainfall runoff. The differences between Pro-Gro soil and biochar-amended soils are most noticeable for the soil-only trays. Pro-Gro soil-only trays released 2956 to $2957 \mathrm{mg}$ of nitrate while the biochar-amended soil-only trays released 599 to $722 \mathrm{mg}$ of nitrate. Biochar-amended soil also released less phosphate than Pro-Gro soil trays, with Pro-Gro soil-only trays releasing 292 to $399 \mathrm{mg}$ of phosphate and biochar-amended soil-only releasing 194 to $213 \mathrm{mg}$ of phosphate. Comparison of the total mass results shows that nitrogen was released from the ProGro soil and biochar-amended soil in much higher amounts than phosphorus. This should be considered a function of the starting Pro-Gro soil and would be expected to vary depending on initial soil parameters.

Table 7: Total Recovered Mass of Measured Nutrients from Rainfall Runoff.

\begin{tabular}{|c|l|c|c|c|c|c|}
\hline \multirow{5}{*}{ Plant Type } & Tray & $\begin{array}{c}\text { Nitrate } \\
(\mathrm{mg})\end{array}$ & $\begin{array}{c}\text { Phosphate } \\
(\mathrm{mg})\end{array}$ & $\begin{array}{c}\text { Total } \\
\text { Phosphorus } \\
(\mathrm{mg})\end{array}$ & $\begin{array}{c}\text { Total } \\
\text { Organic } \\
\text { Carbon } \\
(\mathrm{mg})\end{array}$ & $\begin{array}{c}\text { Inorganic } \\
\text { Carbon } \\
(\mathrm{mg})\end{array}$ \\
\hline \multirow{5}{*}{ Soil Only } & ProGro [P4] & 2957 & 399 & 453 & 3030 & 399 \\
\cline { 2 - 7 } & ProGro [P5] & 2956 & 292 & 317 & 1908 & 234 \\
\cline { 2 - 8 } & Biochar [B2] & 722 & 213 & 247 & 687 & 298 \\
\cline { 2 - 8 } & Biochar [B3] & 599 & 194 & 217 & 595 & 243 \\
\hline \multirow{5}{*}{ Sedum } & ProGro [P2] & 303 & 152 & 216 & 1436 & 288 \\
\cline { 2 - 8 } & ProGro [P7] & 404 & 144 & 199 & 1521 & 233 \\
\cline { 2 - 7 } & Biochar [B6] & 759 & 158 & 183 & 488 & 242 \\
\cline { 2 - 7 } & Biochar [B7] & 67 & 111 & 119 & 425 & 223 \\
\hline \multirow{5}{*}{ Ryegrass } & ProGro [P3] & 157 & 172 & 238 & 1024 & 257 \\
\cline { 2 - 7 } & ProGro [P6] & 2240 & 310 & 352 & 1236 & 322 \\
\cline { 2 - 7 } & Biochar [B4] & 13 & 166 & 151 & 395 & 335 \\
\cline { 2 - 7 } & Biochar [B5] & 63 & 197 & 182 & 439 & 345 \\
\hline
\end{tabular}




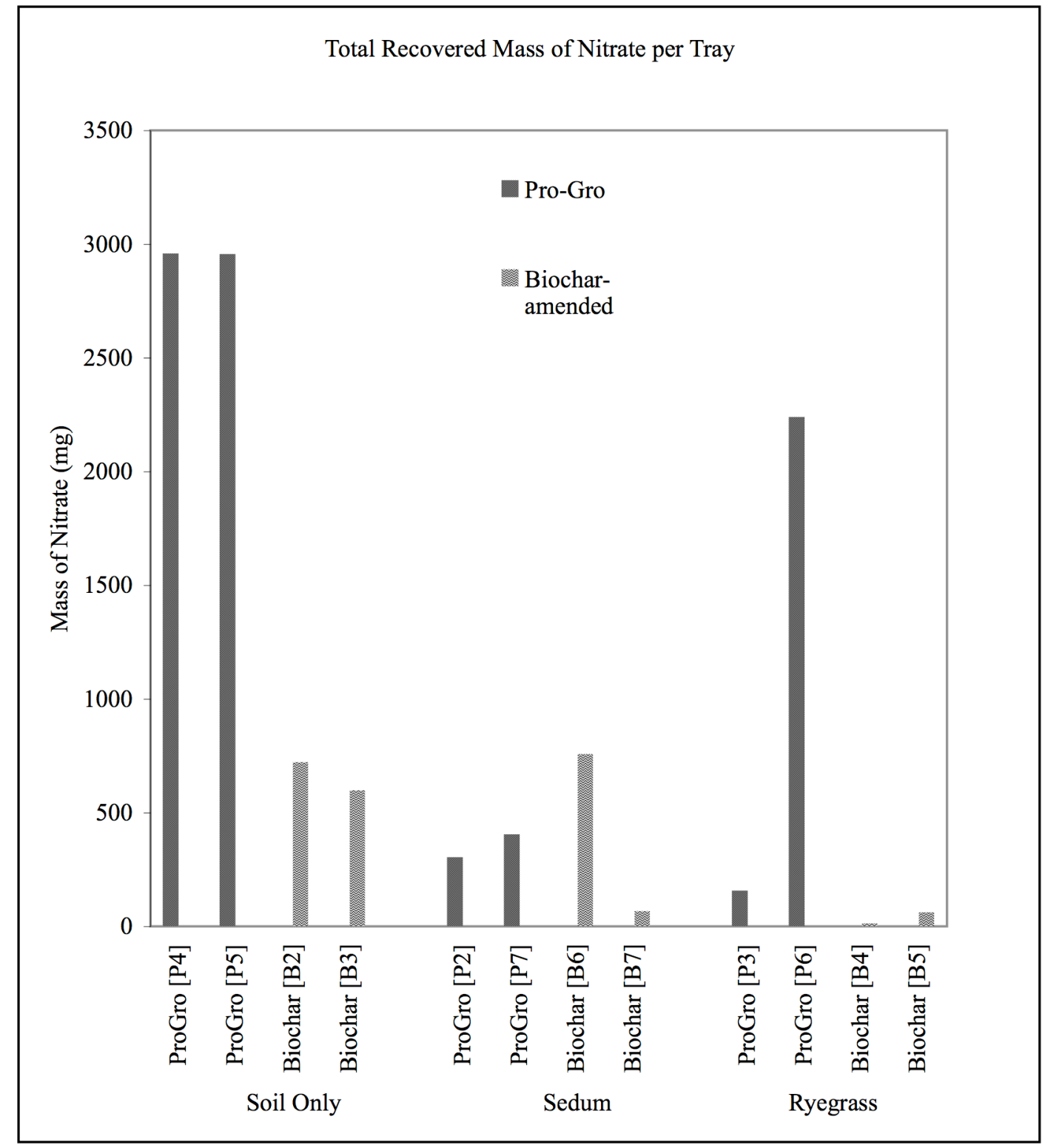

Figure 30: Total mass of nitrate released by tray. 


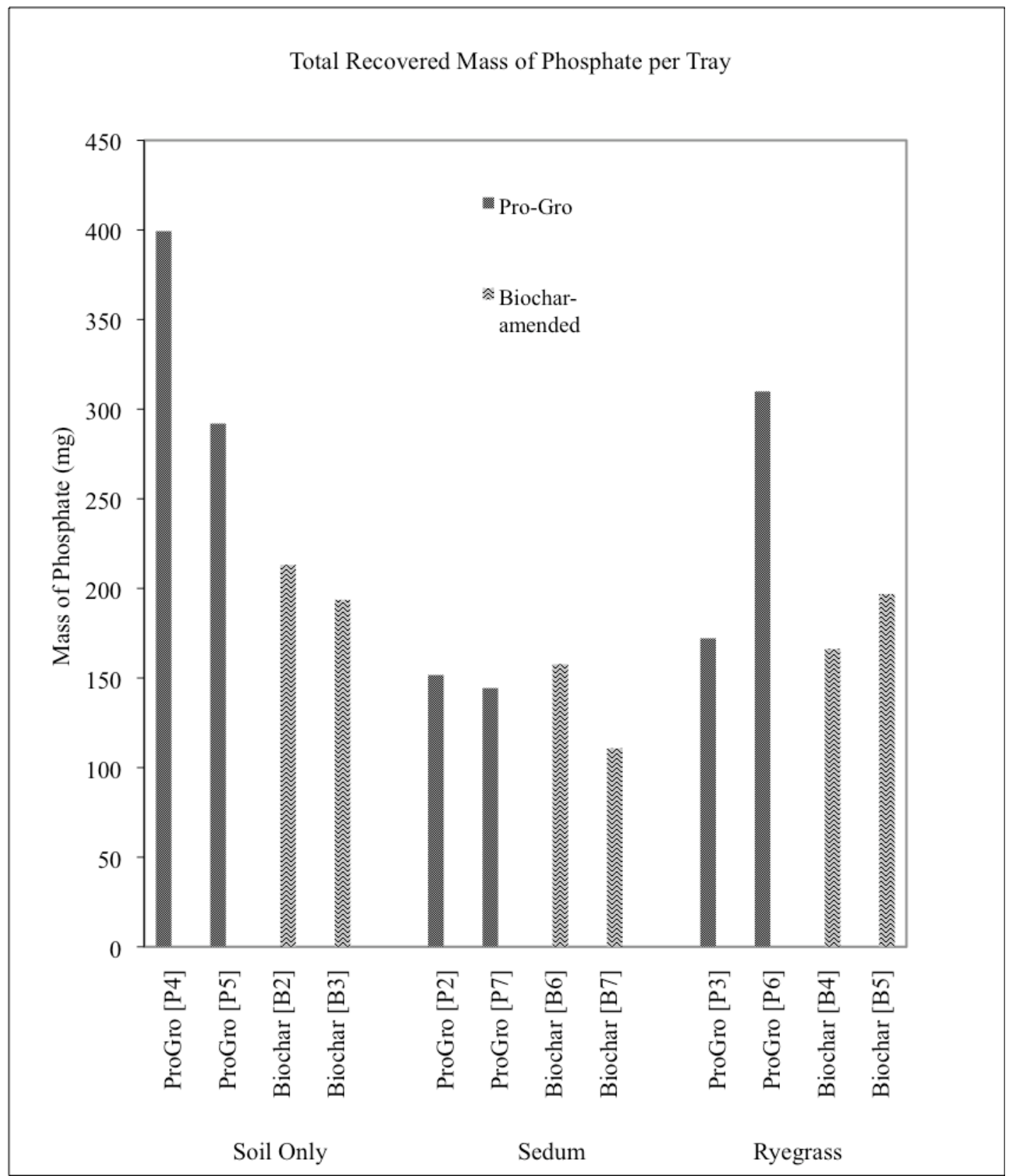

Figure 31: Total mass of phosphate released by tray.

\section{$\underline{\text { Total Organic Carbon and Inorganic Carbon }}$}

Recovered mass of total organic carbon showed large differences between the Pro-Gro and biochar-amended soil (Figure 32). For Pro-Gro soil with and without plants, mass of total organic carbon released into the rainfall runoff ranged from 1024 
to $3030 \mathrm{mg}$ versus all trays containing biochar-amended soil, which released 395 to $687 \mathrm{mg}$ of total organic carbon. In contrast to total organic carbon, mass of inorganic carbon released into the rainfall runoff was similar for both soil types, with Pro-Gro soil releasing a range of 233 to $399 \mathrm{mg}$ and biochar-amended soil releasing a range of 223 to $345 \mathrm{mg}$ inorganic carbon.

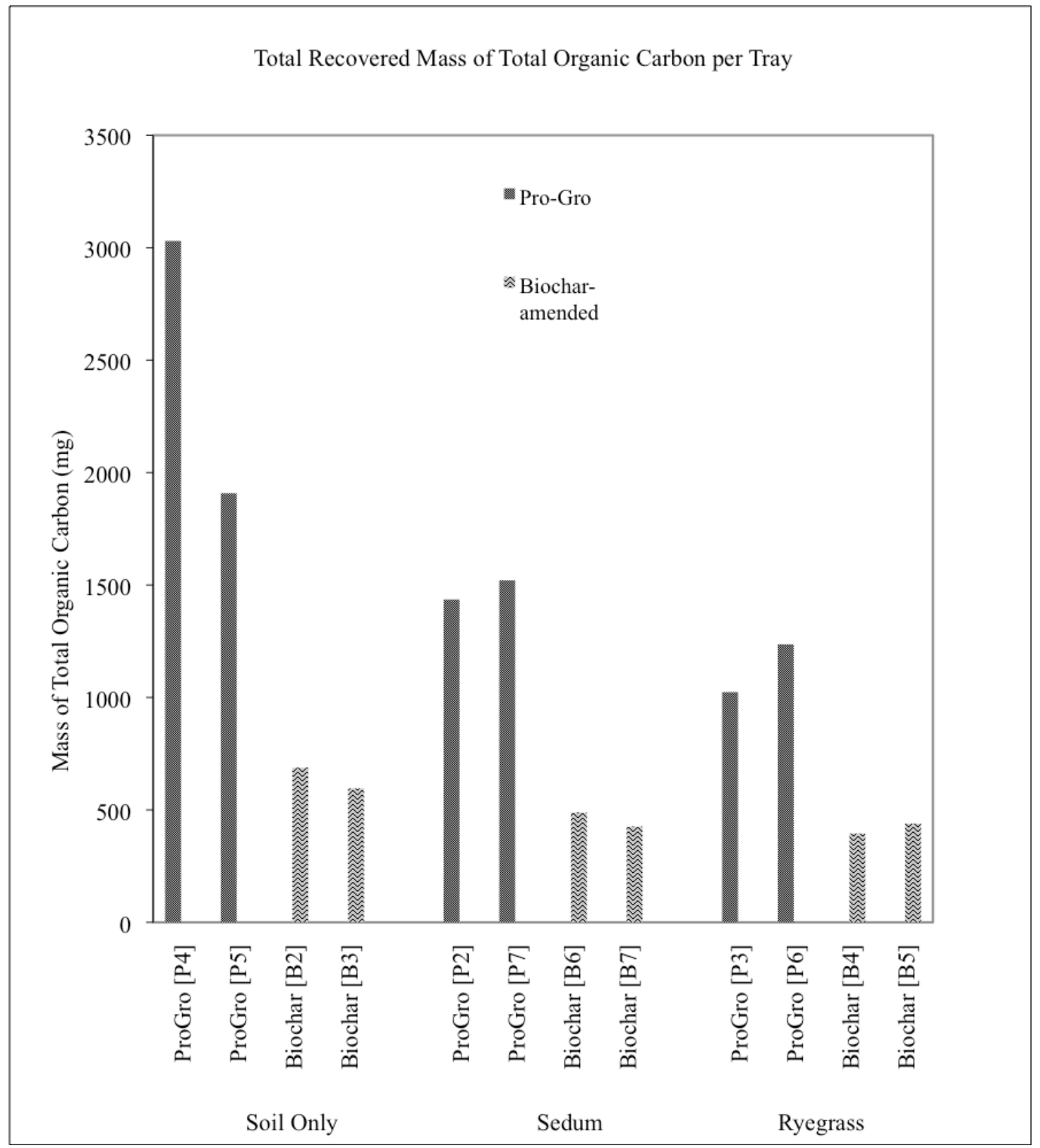

Figure 32: Mass of total organic carbon released by tray. 


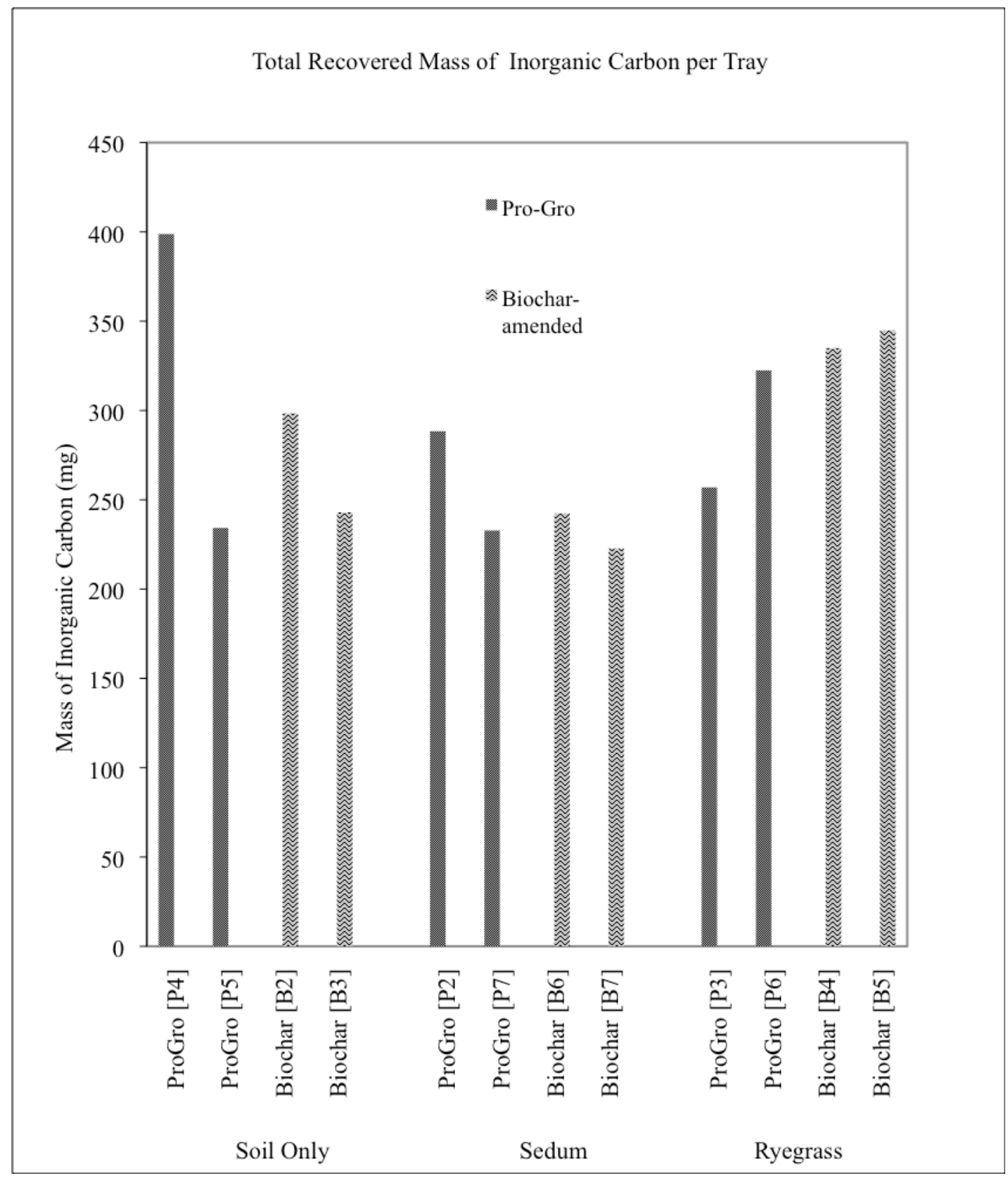

Figure 33: Mass of inorganic carbon released by tray.

\subsection{Soil Nitrate Extraction}

One ryegrass tray (P6) containing Pro-Gro soil showed unexpectedly high concentrations of nitrate. The matching Pro-Gro ryegrass tray $(\mathrm{P} 3)$ that was run at the same time had unexpectedly low concentrations of nitrate. Upon obtaining these 
results, samples were rerun to eliminate an incorrectly run FIA assay as being the cause of discrepancies between the two trays. The second FIA results also showed the same differences in nitrate concentration. Upon further examination of other nitrate results from other trays, one biochar-amended sedum tray (B6) also showed higher nitrate results than would have been expected as compared to its matching tray. To investigate these discrepancies a soil nitrate extraction study was performed.

The nitrate extraction procedure included subjecting each sample to five minutes of shaking. This shaking resulted in biochar-amended soil extraction samples having a high amount of grey particulate and turbidity even after $0.45 \mu \mathrm{m}$ filtration. As this high of turbidity would cause interference with FIA readings, the biocharamended soil samples were discarded. The remaining Pro-Gro soil samples were tested for nitrate on the FIA and the resulting $\mathrm{mg} / \mathrm{g}$ of nitrate are shown in Table 8 . Table 8 shows that differences of extractable nitrate in the soil of the two Pro-Gro ryegrass trays differed greatly, with tray P6 having an average of $0.1 \mathrm{mg} / \mathrm{g}$ and tray P3 having an average of $0.01 \mathrm{mg} / \mathrm{g}$ of extractable nitrate. This difference by a factor of 10 between the two trays' extractable nitrate is approximately replicated by the nitrate concentrations measured in the rainfall runoff samples collected from the trays. Specifically, tray P6 rainfall runoff samples had an average nitrate concentration of $112.8 \mathrm{mg} / \mathrm{l}$ and tray P3 rainfall runoff samples an average concentration of $13.3 \mathrm{mg} / \mathrm{l}$, a difference of a factor of $\approx 10$. The differences in nitrate concentrations between the two Pro-Gro soil ryegrass trays (P6 and P3) rainfall runoff samples and also the high nitrate concentrations found in the biochar-amended sedum tray (B6) rainfall runoff samples are not completely unexpected. Due to the inconsistent makeup of the soil, it 
is not surprising that some trays have higher sources of nitrate than others do. Trays with higher sources of nitrate would naturally result in higher nitrate in rainfall runoff. Table 8: Results of Nitrate Soil Extraction.

\begin{tabular}{|c|c|c|c|}
\hline & $\begin{array}{c}\text { Soil extraction } \\
\text { sample }\end{array}$ & $\begin{array}{c}\text { Nitrate }(\mathrm{mg} / \mathrm{g}) \\
\text { from soil } \\
\text { extraction }\end{array}$ & $\begin{array}{c}\text { Average nitrate (mg/l) } \\
\text { from rainfall runoff } \\
\text { experiments }\end{array}$ \\
\hline \multirow{2}{*}{$\begin{array}{c}\text { ProGro Soil } \\
\text { Only }\end{array}$} & $\mathrm{P} 4 \mathrm{a}$ & 0.39 & \multirow{2}{*}{127.4} \\
\cline { 2 - 3 } & $\mathrm{P} 4 \mathrm{~b}$ & 0.45 & \multirow{2}{*}{13.3} \\
\hline \multirow{2}{*}{$\begin{array}{c}\text { Ryegrass in } \\
\text { ProGro Soil }\end{array}$} & $\mathrm{P} 3 \mathrm{a}$ & 0.01 & \multirow{2}{*}{13.3} \\
\cline { 2 - 3 } & $\mathrm{P} 3 \mathrm{~b}$ & 0.01 & \multirow{2}{*}{112.8} \\
\cline { 2 - 3 } & $\mathrm{P} 6 \mathrm{a}$ & 0.11 & \\
\hline
\end{tabular}

\section{$\underline{3.8 \text { Total Dissolved Solids and Suspended Solid Concentrations }}$}

Runoff samples from a Pro-Gro soil ryegrass tray and a biochar-amended ryegrass tray were evaluated to determine if the turbidity in the samples was a result of total dissolved solids (TDS) or suspended solids concentration (SSC). All samples showed higher total dissolved solids concentrations than suspended solid concentrations as seen in Table 9, demonstrating that total dissolved solids is the dominant source of turbidity in the runoff water for both Pro-Gro and biocharamended soils. Furthermore, both Pro-Gro and biochar-amended soils have roughly equal concentrations of total dissolved solids. Pro-Gro soil rainfall runoff samples had much higher values of suspended solid concentrations than biochar-amended rainfall runoff samples, indicating that biochar-amended soil is also more effective at filtering out suspended solids. 
Table 9: Total Dissolved Solids (TDS) and Suspended Solids (SSC).

\begin{tabular}{|l|c|c|c|}
\hline Sample: & $\begin{array}{c}\text { Solid present in } \\
\text { samples (mg/l) }\end{array}$ & TDS mg/1 & SSC mg/1 \\
\hline & & & \\
\hline Tank B & 19.7 & 21.7 & -1.9 \\
\hline & & & \\
\hline P6_1 & 406.6 & 274.6 & 132.0 \\
\hline P6_3 & 385.9 & 234.0 & 151.9 \\
\hline P6_5 & -99.4 & 211.3 & -310.7 \\
\hline P6_7 & 289.4 & 194.5 & 94.9 \\
\hline P6_9 & 323.7 & 179.2 & 144.5 \\
\hline P6_10 & 224.6 & 196.0 & 28.6 \\
\hline & & & \\
\hline B5_1 & 310.1 & 239.8 & 70.3 \\
\hline B5_3 & 226.0 & 226.1 & -0.1 \\
\hline B5_5 & 236.2 & 211.3 & 24.9 \\
\hline B5_7 & 226.0 & 200.8 & 25.2 \\
\hline B5_9 & 212.6 & 192.4 & 20.2 \\
\hline B5_11 & 218.9 & 194.5 & 24.4 \\
\hline B5_12 & 207.0 & 201.8 & 5.1 \\
\hline B5_13 & 297.4 & 247.7 & 49.7 \\
\hline
\end{tabular}

*Samples in grey fell over during drying process and results may be compromised. 


\subsection{CONCLUSION}

Addition of $7 \%$ biochar by weight to Pro-Gro extensive mix, a soil designed for greenroofs, resulted in several benefits including: a decrease of nitrogen, phosphorus, and organic carbon concentrations entering into the rainfall runoff, increased water retention, and reduced turbidity of rainfall runoff. Biochar-amended soil showed a reduction of total organic carbon in the rainfall runoff by a factor of 3 to 4 for both soil-only and plant trays. The reduction of total organic carbon in the rainfall runoff corresponded with a distinct visual difference of turbidity in the collected rainfall runoff samples. Samples recovered from Pro-Gro soil were dark to medium tea-colored, while samples collected from biochar-amended soil were only slightly cloudy and almost clear. The dominant source of turbidity resulted from total dissolved solids for both soil types. Unlike total organic carbon, inorganic carbon concentrations released into the rainfall runoff were not effected by the presence of biochar in the soil. Addition of biochar addition to the soil also resulted in an approximate $4.4 \%$ increase in water retention by trays containing close-to-saturated soil.

The presence of ryegrass and sedum plants both demonstrated decreasing effects on nitrate concentrations in the rainfall runoff for both soil types, although results regarding differences of nitrate retention by individual plant species were not conclusive. The prototype greenroof trays tested in this study showed that biocharamended trays resulted in a 3- to 25 -fold decrease in release of nitrate and total nitrogen concentrations into the rainfall runoff. Phosphorus results from trays planted with sedum indicate that sedum interacted with both soils to cause a decrease of 
phosphorus in the rainfall runoff regardless of soil type. When sedum was not present, biochar-amended soil reduced the amount of phosphate released into the rainfall runoff by 5 to $7 \mathrm{mg} / \mathrm{l}$. Release of total phosphorus concentrations into the rainfall runoff water were also decreased by biochar-amendment. Overall, the addition of biochar to greenroof soil resulted in decreased nutrient concentrations in the rainfall runoff. Adding biochar to soil can be a way to improve downstream water quality by reducing nitrogen, phosphorus, and organic carbon concentrations and decreasing turbidity in runoff. 
WORKS CITED

Ammann, A, Hoehn, E., and Koch, S. Ground water pollution by roof runoff infiltration evidenced with multi-tracer experiments. Water research (Oxford). 2003, 37, 1143-1153.

Beaton, J., Peterson, H., and Bauer, N. Some aspects of phosphate adsorption by charcoal. Soil Science Society of America Proceedings. 1960, 24, 340 - 346.

Berghage, R., Beattie, D., Jarrett, A., and O'Connor, T. Greenroof runoff water quality. Proceedings of the Greening Rooftops for Sustainable Communities, Minneapolis, 2007.

Berghage, R., Wolf, A., and Miller, C. Testing green roof media for nutrient content. Proceedings of the Greening Rooftops for Sustainable Communities, Baltimore, 2008.

Buccola, Norman. A laboratory comparison of green roof runoff. A thesis submitted in partial fulfillment of the requirements for the degree of Masters of Science in Civil and Environmental Engineering, Portland State University, Portland, OR, 2008.

Bureau of Environmental Services, Sewer and drainage facilities design manual. City of Portland. (2007).

Cheng, C., Lehmann J., and Engelhard M., Natural oxidation of black carbon in soils: changes in molecular form and surface charge along a climosequence. Geochimica et Cosmochimica Acta. 2008. 72, 1598-1610.

Drever, J. I. The Geochemistry of Natural Waters. 3rd ed. Upper Saddle River: Prentice Hall, 1997.

Droste, R. L. Theory and Practice of Water and Wastewater Treatment. John Wiley and Sons, 1997.

Dynamotive in Iowa Biochar Test to Boost Corn Yields, Water Quality and Sequester Carbon Joint Research Project to Use Ancient Amazonian Farmland Soil Enrichment Techniques. Dynamotive the Evolution of Energy. 29 May 2007. Dynamotive USA, Inc. Web. 16 Feb 2010. <http://www.dynamotive.com/2007/05/29/dynamotive-iniowa-biochar-test-to-boost-corn-yields-water-quality-and-sequester-carbon-jointresearch-project-to-use-ancient-amazonian-farmland-soil-enrichment-techniques/>.

Gadd, J. and Kennedy, P. House roof runoff: is it as clean as we think? $2^{\text {nd }}$ South Pacific Stormwater conference. 2001. 
Gaunt, J. and Lehmann, J. Energy balance and emissions associated with biochar sequestration and pyrolysis bioenergy production. Environmental Science and Technology. 2008, 42, 4152-4158.

Glaser, B., Balashov, E., Haumaier, L., Guggenberger, G., and Zech, W. Black carbon in density fractions of anthropogenic soils of the Brazilian Amazon region. Organic Geochemistry. 2000, 31, 669-678.

Glaser, B., Lehmann, J., and Zech, W. Ameliorating physical and chemical properties of highly weathered soils in the tropics with charcoal - a review. Biology and Fertility of Soils. 2002, 35:219-230.

Gray, J., Glysson, G., Turcios, L., and Schwarz, G. Comparability of suspendedsediment concentration and total suspended solids. Water-Resources Investigations Report 00-4191. Reston, VA: USGS, 2000.

Hathaway, A., Hunt, W., and Jennings, G. A Field Study of Green Roof Hydrologic and Water Quality Performance. Transactions of the ASABE. 2008 51(1), 37-44.

Hunt, W., Hathaway, A., Smith, J., and Calabria, J. Choosing the right green roof media for water quality. Proceedings of the Greening Rooftops for Sustainable Communities, Boston, 2006.

Lehmann, J., Da Silva Jr., J., Steiner, C., Nehls, T., Zech, W. and Glaser, B. Nutrient availability and leaching in an archaeological Anthrosol and a Ferralsol of the Central Amazon basin: fertilizer, manure and charcoal amendments. Plant and Soil. 2003. $249,343-357$.

Lehmann, J., Lan, Z., Hyland, C., Sato, S., Solomon, D., and Ketterings, Q. Long-term dynamics of phosphorus forms and retention in manure-amended soils. Environmental Science and Technology. 2005. 39, 6672-6680.

Lehmann, J., Gaunt, J., and Rondon, M., Bio-char sequestration in terrestrial ecosystems - a review. Mitigation and Adaptation Strategies for Global Change.

2006. $11,403-427$.

Liang, B., Lehmann, J,. Solomon, D., Kinyangi, J., Grossman, J., O'Neill, B., Skjemstad, J., Thies, J., Luizão, F., Petersen, J., and Neves, E. Black carbon increases cation exchange capacity in soils. Soil Science Society of America Journal. 2006. 70: 1719-1730.

Meera, V. and Ahammed, M. Water quality of rooftop rainwater harvesting systems: a review. Water $S R T$ - Aqua 55. 2006. 257-268 
National Phosphorus Research Protocols. SERA-17 Organization to minimze phosphorus losses from agriculture, SERA-17 Publications. 29 Nov 2005. Web. 5 Mar 2009. <http://www.sera17.ext.vt.edu/SERA_17_Publications.htm>.

Owen, C., Ameel, J., and Axler, R. Total nitrogen and total phosphorus simultaneous digestion.University of Minnesota soil and water laboratory. 1992. Web. 27 Feb 2009. $<$ http://swroc.cfans.umn.edu/soilandwater/lab/sop/tnandtp.pdf $>$.

Retzlaff, W., Ebbs, S., Alsup, S., Morgan, E., Woods, V., and Luckett, K. What is that running off of my green roof? Proceedings of the Greening Rooftops for Sustainable Communities, Baltimore, 2008.

Rondon, M., Lehmann, J., Ramírez, J., and Hurtado, M. Biological nitrogen fixation by common beans (Phaseolus vulgaris L.) increases with bio-char additions. Biology and Fertility in Soils 2007. 43, 699-708.

Saylor, J. Plant Encyclopedia. Michigan State University. 2008. Web. 17 Feb 2010. $<$ http://msuplants.com/pd.asp?pid=2339 $>$.

Sekhon, J. Multivariate and Propensity Score Matching Software with Automated Balance Optimization: The Matching package for R. R version 2.10.0 2009.

Sideman, E. Basics of Organic Soil Fertility. Maine Organic Farmers and Gardeners Association 2006. Web. 7 Jan 2010.

$<$ http://www.mofga.org/Default.aspx?tabid=518>.

Shreve, E., and Downs, A. Quality-assurance plan for the analysis of fluvial sediment by the U.S. Geological Survey Kentucky water science center sediment laboratory: U.S. Geological Survey Open-File Report 2005. 28 p.

Sohi, S.. Loez-Capel, E., Krull, E., and Bol, R. Biochar's roles in soil and climate change: A review of research needs. CSIRO Land and Water Science Report. 2009. 64 pp.

Steiner, C., Teixeira, W., Lehmann, J., Nehls, T., Macedo, J., Blum, W., and Zech, W. Long term effects of manure, charcoal and mineral fertilization on crop production and fertility on a highly weathered Central Amazonian upland soil. Plant and Soil. 2007. 291: 275-290 .

Teemusk, A. and Mander, U. Rainwater runoff quantity and quality performance from a greenroof: The effects of short-term events. Ecological Engineering. 2007. 30, 271.

Thomas, P. and Greene, G. Rainwater quality from different roof catchments. Water Science Technology. 1993. 28 (305), 291-297. 
Uphoff, N. Biological approaches to sustainable soil systems. Books in soils, plants, and the environment, v. 113. Boca Raton: CRC/Taylor \& Francis, 2006.

USDA: Conservation Plant Characteristics for Lolium perenne ssp. multiflorum. USDA NRCS Plants database. Web. 10 Jan 2010.

$<$ http://plants.usda.gov/java/charProfile?symbol=LOPEM2>.

Van Metre, P., and Mahler, B. The contribution of particles washed from rooftops to contaminant loading to urban streams. Chemosphere. 2003. 52, (10), 1727-1741.

Van Seters, T., Rocha, L., and MacMillan, G. Evaluation of the runoff quantity and quality performance of an extensive green roof in Toronto, Ontario. Proceedings of the Greening Rooftops for Sustainable Communities, Minneapolis, 2007. 
APPENDIX A: Phosphate and Nitrate FIA Programs

Program to Test Phosphate on the FIA

FIAlab for Windows 5.9.310

' Phosphate Assay

' FIA Template For FIAlab-2500 System

Global Logon ' logon to all components

Sample Description ' load sample description file

Injection Valve Sample Load

Optimize_FIAlab2500

' Set Wavelengths (for Ortho)

' note: for Olsen or Bray set wavelengths to

' $880 \quad 890 \quad 900 \quad 925 \mathrm{~nm}$

Hardware Settings Wavelength $1(\mathrm{~nm}) 660$

Hardware Settings Wavelength $2(\mathrm{~nm}) 860$

Hardware Settings Wavelength $3(\mathrm{~nm}) 530$

Hardware Settings Wavelength 4 (nm) 490

Hardware Settings Use Wavelength 4 as Reference

'set delay time, start pump to prime lines

Valve Delay $5000 \quad$ ' sample inject (msec)

Peristaltic Pump Clockwise(\%) 55

Delay (sec) 40

Hardware Settings Optimize Integration

'Put autosampler in first sample (usually a blank)

Next Sample

Delay (sec) 25

LoopStart (\#) 5000

'inject sample load next sample

autosampler wash

Analyte New Sample

Delay (sec) 4

Next Sample

Injection Valve Sample Inject

Delay (sec) 3

'perform reference scan and start absorbance scans 
Spectrometer Reference Scan

Spectrometer Absorbance Scanning

Delay (sec) 30

Spectrometer Stop Scanning

'Refresh plots and update concentrations

Refresh Plot

' method clean up (at end of run)

If sampleid $<0$ Then

autosampler Wash

' Save Data Date-Time .dat

End If

Loop End

Program to Test Nitrate on the FIA

FIAlab for Windows 5.9.310

' Nitrate/Nitrite Assay

' FIA Template For FIAlab-2500 System

Global Logon ' logon to all components

Sample Description ' load sample description file

Injection Valve Sample Load

Optimize_FIAlab2500

' Set Wavelengths

Hardware Settings Wavelength 1 (nm) 540

Hardware Settings Wavelength 2 (nm) 580

Hardware Settings Wavelength 3 (nm) 620

Hardware Settings Wavelength 4 (nm) 650

Hardware Settings Use Wavelength 4 as Reference

'set delay time start pump to prime lines

Valve Delay $5000 \quad$ ' sample inject (msec)

Peristaltic Pump Clockwise(\%) 50

Delay (sec) 40

Hardware Settings Optimize Integration 
'Put autosampler in first sample (usually a blank)

Next Sample

Delay (sec) 25

LoopStart (\#) 5000

'inject sample load next sample

autosampler wash

Analyte New Sample

Delay (sec) 4

Next Sample

Injection Valve Sample Inject

Delay (sec) 3

'perform reference scan and start absorbance scans

Spectrometer Reference Scan

Spectrometer Absorbance Scanning

Delay (sec) 25

Spectrometer Stop Scanning

'Refresh plots and update concentrations

Refresh Plot

' method clean up (at end of run)

If sampleid $<0$ Then

autosampler Wash

' Save Data Date-Time .dat

End If

Loop End 
APPENDIX B: Total Phosphorous and Total Nitrogen

Simultaneous Persulfate Digestion

Preparation and Protocol

\section{Reagents:}

Reagents were stored in capped amber bottles.

$\underline{\mathrm{K}}_{2} \underline{\mathrm{S}}_{2} \underline{\mathrm{O}}_{8} \underline{\text { Reagent: }}$

$20 \mathrm{~g} \mathrm{~K}_{2} \mathrm{~S}_{2} \mathrm{O}_{8}$

$500 \mathrm{ml}$ nanopure water

NaOH Reagent:

$30 \mathrm{~g} \mathrm{NaOH}$

$250 \mathrm{ml}$ nanopure water

\section{Procedure:}

For each sample:

$7 \mathrm{mls}$ of gently mixed sample was pipetted in a $15 \mathrm{ml}$ glass test tube. $2.33 \mathrm{ml}$ of $\mathrm{K}_{2} \mathrm{~S}_{2} \mathrm{O}_{8}$ reagent was added, followed by $116.7 \mathrm{ul}$ of $\mathrm{NaOH}$ reagent.

Tubes were capped and gently mixed. Tubes were then digested in an All American Electric Pressure Steam Sterilizer, Model 25X sterilizer for a minimum of 35 minutes at 17 to 21 psi.

Samples were allowed to cool and then stored at $4^{\circ} \mathrm{C}$ until processed on FIA 2500.

\section{Prior to processing on FIA:}

Samples were allowed to come to room temperature.

$116.7 \mathrm{ul} \mathrm{NaOH}$ was added to each sample and gently mixed.

FIA phosphate and nitrate protocols were run on digested samples to obtain total phosphorus and total nitrogen concentrations. All reagents used for this step were the same as for normal FIA phosphate and 
APPENDIX C: FIA Uncertainty Analysis for Phosphate and Nitrate.

The sample variation of the phosphate and nitrate assays performed on the FIA were determined by taking a large pooled sample of runoff water from a tray containing Pro-Gro soil, mixing the pooled sample thoroughly, and then rapidly pouring aliquots into 30 test tubes. FIA phosphate and nitrate assays were then run on the 30 samples to determine sample variation resulting from the nitrate or phosphorus assay. The obtained concentrations for nitrate and phosphate are plotted in Figure 1. Nitrate concentrations had a mean of $78.3 \mathrm{mg} / \mathrm{l}$, a standard deviation of $1.0 \mathrm{mg} / \mathrm{l}$, and a variability coefficient of $1.3 \%$. Phosphate concentrations had a mean of $13.5 \mathrm{mg} / \mathrm{l}$, a standard deviation of $0.6 \mathrm{mg} / \mathrm{l}$, and a variability coefficient of $4.4 \%$. Both nitrate and phosphate had a probability of $3 \%$ that a sample would be an actual outlier. The variation of results seen in Figure 1 is assumed to be due to the FIA's spectrophotometer being affected by varying turbidity in the samples. The phosphate assay is thermo-controlled, while the nitrate assay is not. The greater variability seen by nitrate samples may be a result of the FIA being subjected to changing airflows that often occurred in the lab where the FIA was located. 


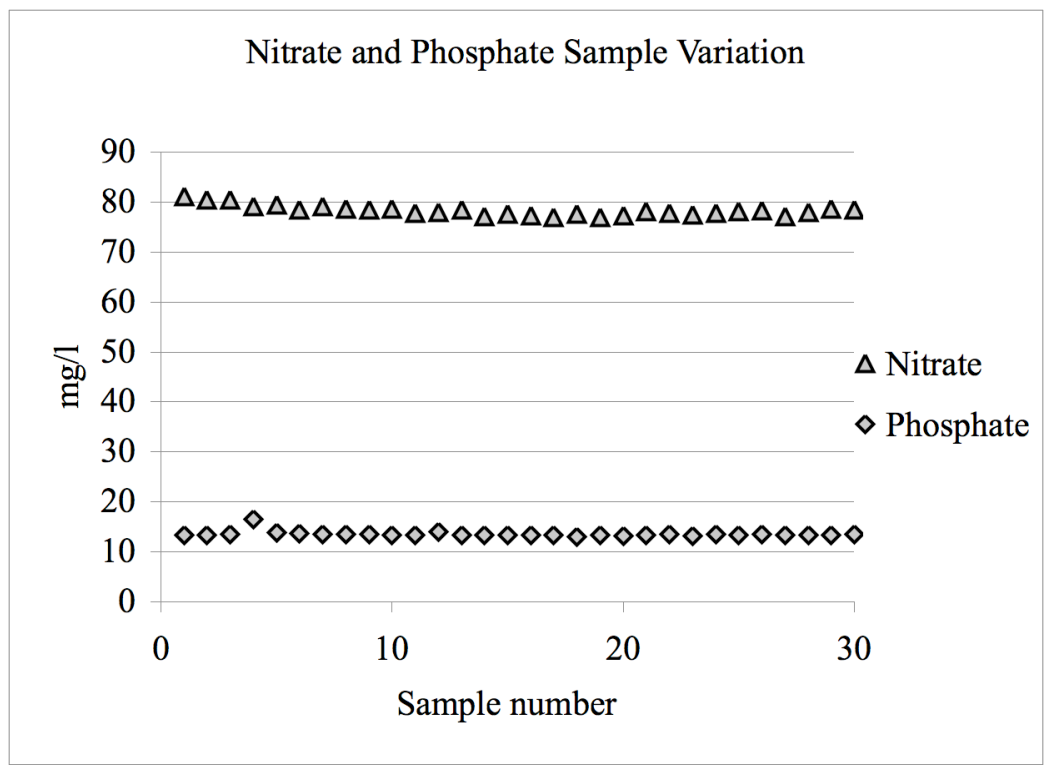

Figure 1: Phosphate and nitrate results for all 30 samples.

Table 1 and Table 2 show the raw data used for the uncertainty analysis and the obtained sample statistics. Chauvent's crition was used to check for outliers. Phosphate and nitrate assays each had one outlier out of the 30 tested samples and therefore outliers are expected to occur $3 \%$ of the time. 
Table 1: Raw data for FIA Uncertainty Analysis for Phosphate and Nitrate Sample Variability on FIA

\begin{tabular}{|l|r|r|}
\hline & & \\
Sample & Phosphate in ppm & Nitrate in ppm \\
\hline P1 & 13.3207 & 81.1742 \\
P2 & 13.33 & 80.4006 \\
P3 & 13.4899 & 80.5611 \\
P4 & 16.5066 & 79.1092 \\
P5 & 13.8805 & 79.4787 \\
P6 & 13.7431 & 78.5148 \\
P7 & 13.5765 & 79.1438 \\
P8 & 13.4791 & 78.7175 \\
P9 & 13.5524 & 78.4343 \\
P10 & 13.3987 & 78.5764 \\
P11 & 13.3081 & 77.7293 \\
P12 & 14.0739 & 77.9245 \\
P13 & 13.3626 & 78.4282 \\
P14 & 13.2865 & 77.1654 \\
P15 & 13.4186 & 77.722 \\
P16 & 13.3082 & 77.3061 \\
P17 & 13.4307 & 77.0152 \\
P18 & 13.101 & 77.6741 \\
P19 & 13.3869 & 77.0532 \\
P20 & 13.1541 & 77.3584 \\
P21 & 13.3581 & 78.1221 \\
P22 & 13.5844 & 77.8369 \\
P23 & 13.2175 & 77.4784 \\
P24 & 13.5617 & 77.8014 \\
P25 & 13.4132 & 78.1891 \\
P26 & 13.5339 & 78.3195 \\
P27 & 13.421 & 77.219 \\
P28 & 13.359 & 78.0235 \\
P29 & 13.349 & 78.7036 \\
P30 & 13.5339 & 78.4326 \\
\hline
\end{tabular}

Highlighted results are outliers by Chauvent's crition.

Table 2: Nitrate and Phosphate FIA variation:

\begin{tabular}{|l|c|c|c|c|c|c|c|}
\hline \multicolumn{10}{|c|}{ Chauvenet's crition: } \\
\hline \multicolumn{1}{|c|}{ Assay } & $\mathrm{n}$ & $\mathrm{c}$ & $\begin{array}{c}\text { Standard } \\
\text { Deviation }\end{array}$ & $\mathrm{c} \times \mathrm{SD}$ & Mean & $\begin{array}{c}\text { Low end } \\
\text { of range }\end{array}$ & $\begin{array}{c}\text { High end } \\
\text { of range }\end{array}$ \\
\hline Phosphate & 30 & 2.3710 & 0.5929 & 1.4058 & 13.5500 & 12.1442 & 14.9558 \\
\hline Nitrate & 30 & 2.3710 & 1.0344 & 2.4525 & 78.3200 & 75.8675 & 80.7725 \\
\hline
\end{tabular}


APPENDIX D: Acid Preservation on Total Phosphorus and Total Nitrogen.

Initial total nitrogen and total phosphorus results showed inconsistencies in serial dilution checks. Acid preservation by sulfuric acid $\left(\mathrm{H}_{2} \mathrm{SO}_{4}\right)$ of the samples was tested for being the possible cause of the inconsistencies. As the testing of the soilonly and sedum rainfall runoff samples for total nitrogen and total phosphorus revealed the problem, collected rainfall runoff samples from ryegrass trays were used to perform a comparison study of samples preserved with acid versus samples not preserved with acid. For the comparison study, all collected runoff samples were first tested for total phosphorus and total nitrogen within 48 hrs of being collected.

Remaining sample volumes were fixed with sulfuric acid and allowed to sit for three weeks, as a previous test had suggested that the acid effect happened over time. Acidfixed samples were then digested and tested for total phosphorus and total nitrogen.

\section{Total Nitrogen:}

Plotting non acid-fixed samples verses acid-fixed samples for total nitrogen concentrations clearly showed that acid preservation had a significant effect on the total nitrogen values (Figure 1). If the acid preservation had no effect and the sample results were the same, all points would have plotted along the $y=x$ line. The differences between the total nitrogen and acid-fixed total nitrogen results give a standard deviation of $70.2 \mathrm{mg} / \mathrm{l}$ versus a standard deviation of close to zero if the acid- 
fixing had no effect. The total nitrogen samples that had been acid-fixed were clearly compromised.

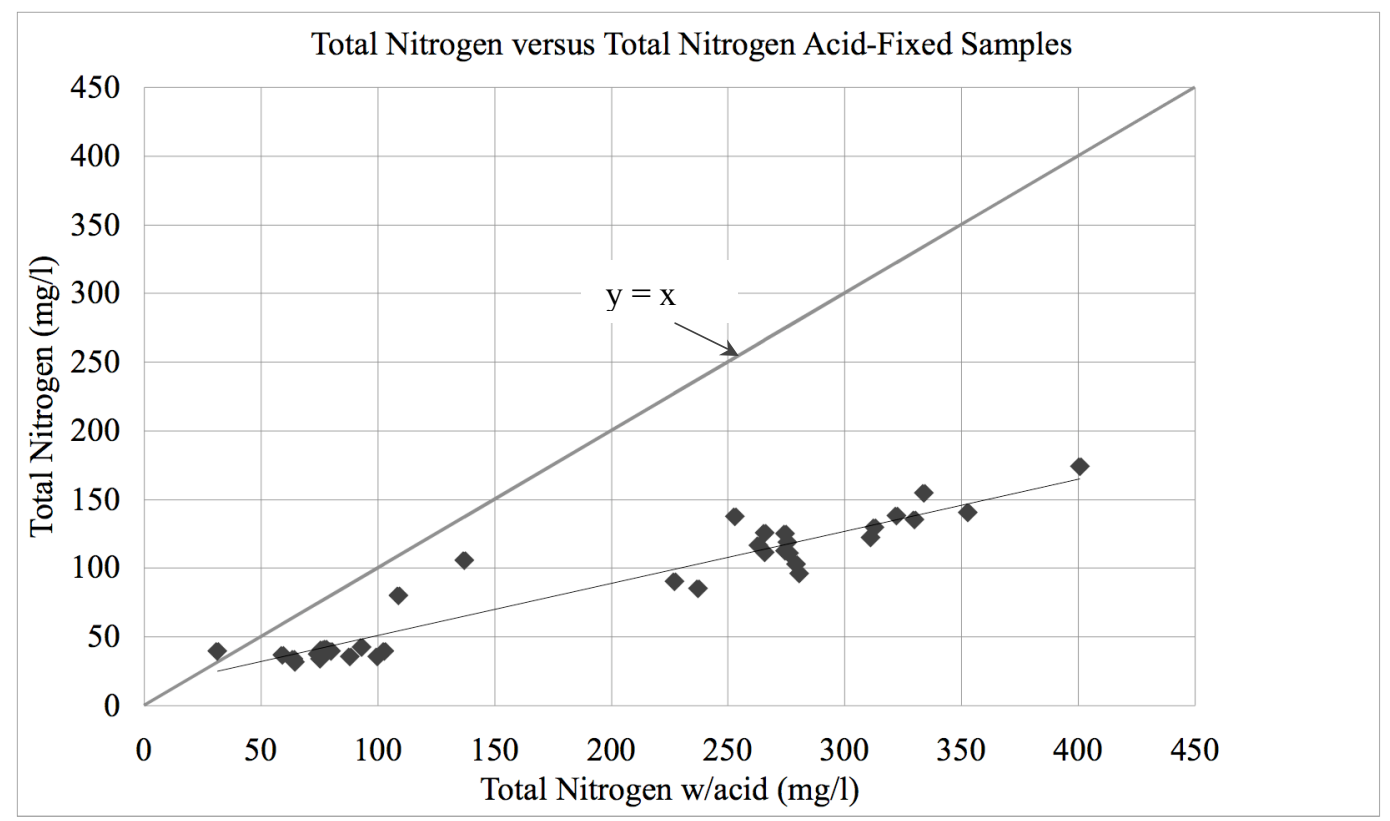

Figure 1: Total nitrogen samples versus acid-fixed total nitrogen samples.

\section{Total Phosphorus:}

Chauvenet's crition for outliers was applied to the total phosphorus samples results. One sample out of the 34 tested was removed from further calculations as it was shown to be an outlier by Chauvenet's crition. As the uncertainly analysis of the phosphate FIA assay showed that one sample out of every 30 is expected to be outlier, at least one outlier was expected. 
Table 1: Chauvenet's crition on evaluating acid-treated total phosphorus samples

\begin{tabular}{|c|c|c|c|c|c|c|c|}
\hline \multicolumn{10}{|c|}{ Chauvenet's crition: } \\
\hline \multicolumn{10}{|c|}{ Assay } & $\mathrm{n}$ & $\mathrm{c}$ & $\begin{array}{c}\text { Standard } \\
\text { Deviation }\end{array}$ & $\mathrm{c} \times \mathrm{xD}$ & Mean & $\begin{array}{c}\text { Low end } \\
\text { of range }\end{array}$ & $\begin{array}{c}\text { High end } \\
\text { of range }\end{array}$ \\
\hline $\begin{array}{c}\text { Total } \\
\text { Phosphorus }\end{array}$ & 34 & 2.4219 & 4.5371 & 10.9884 & 18.3771 & 7.3887 & 29.3654 \\
\hline $\begin{array}{c}\text { Total } \\
\text { Phosphorus: } \\
\text { Acid-treated } \\
\text { samples }\end{array}$ & 34 & 2.4219 & 1.4907 & 3.6102 & 18.7745 & 15.1642 & 22.3847 \\
\hline
\end{tabular}

Acid fixed samples were plotted against non-acid-fixed samples to see similarities. If the samples were the same, all points would have plotted along the $y=$ $\mathrm{x}$ line. The least squares fit for the plotted points were calculated and are shown in Figure 2 below.

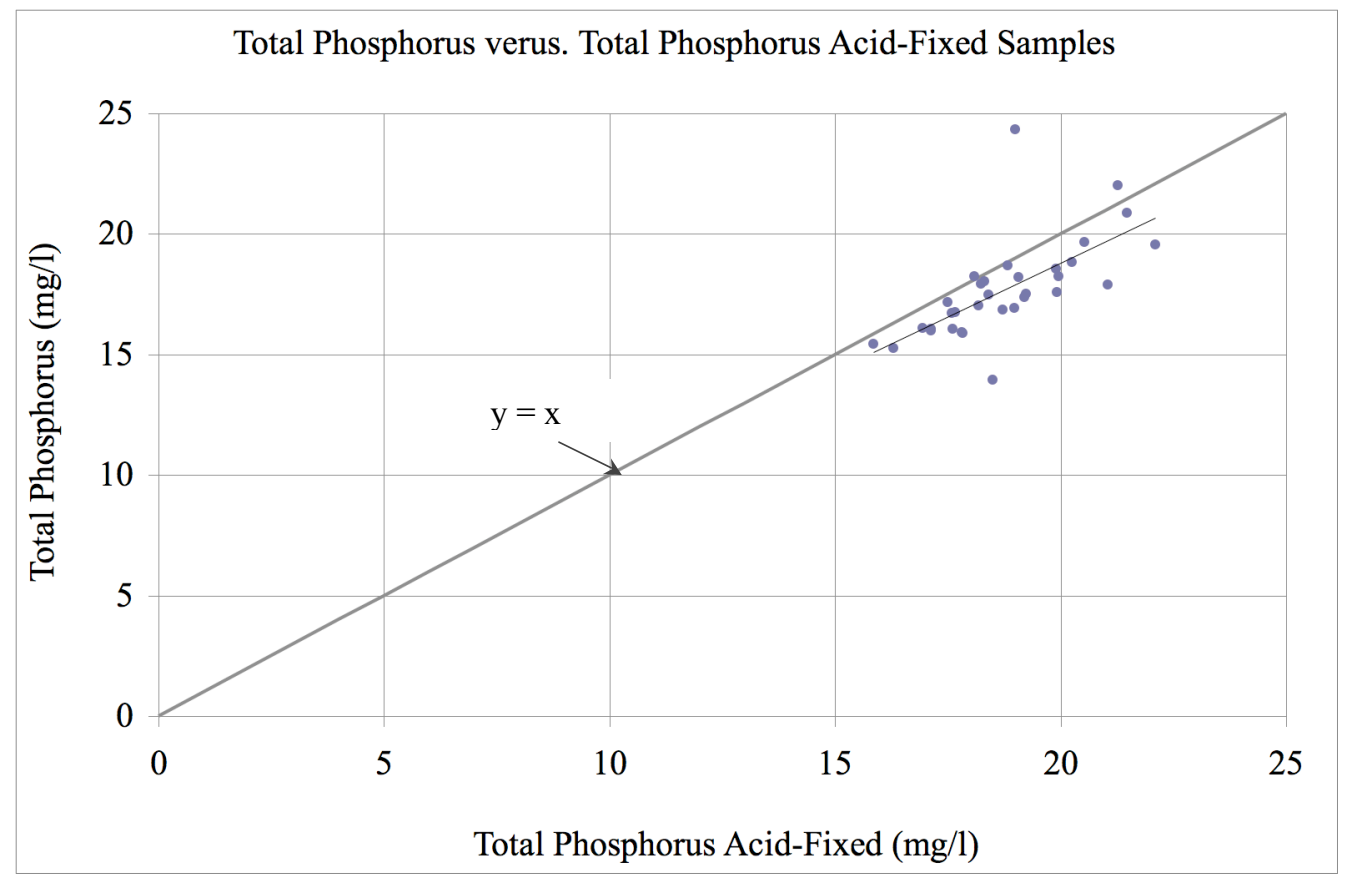

Figure 2: Total phosphorus samples versus acid-fixed total phosphorus samples.

The points plotted close to the $\mathrm{y}=\mathrm{x}$ line, although not on the line, showing some difference caused by the acid preservation. The least squares fit of the points 
resulted in a trend line with the equation $y=0.8918 x+0.9656$. This equation can be used to calculate total phosphorus values from total phosphorus treated with acid values. To verify the validity of this assumption the cumulative distribution of the residuals was plotted in Figure 3 and then compared to the cumulative distribution of the residuals of the sample variability test run on phosphate. This is appropriate as the final step for determining total phosphorus and total nitrogen is to run phosphate and nitrate analysis on the digested samples. The residuals of the phosphate uncertainly analysis and the residuals of the acid-fixing comparison uncertainly analysis are compared in Figure 3 showing that there are other errors in the acid-preserved samples than those caused by the addition of acid. The sample repeatability errors of phosphate, shown by the open circles, are a result of variability in the samples and how that variability affects readings taken by the spectrophotometer on the FIA. Total phosphorus values for acid-fixed samples are accurate to within a $1.5 \mathrm{mg} / \mathrm{l}$, and to within $0.6 \mathrm{mg} / 1$ for samples not acid-fixed. 


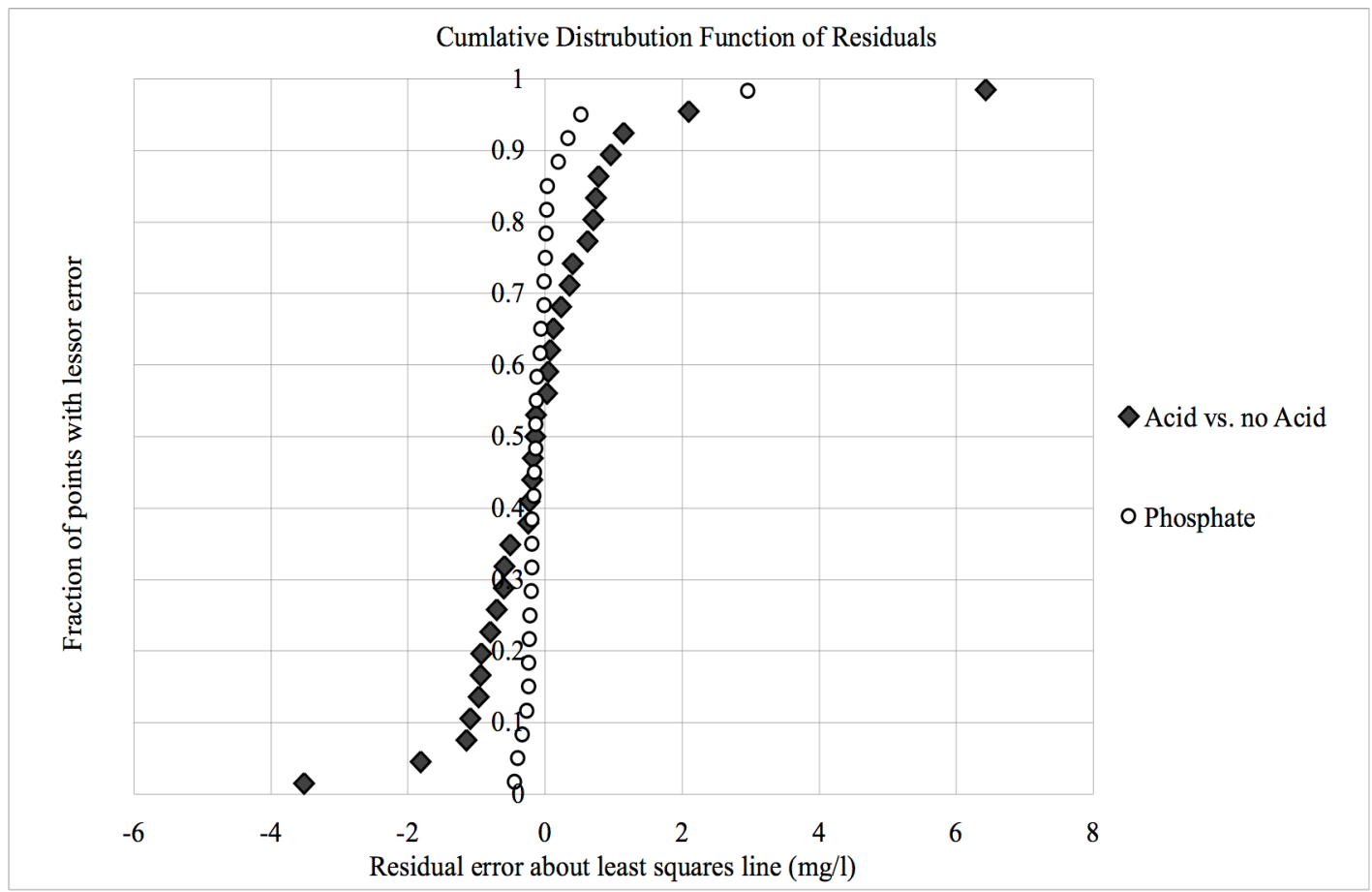

Figure 3: Cumulative distribution function of residuals: Acid-fixed versus. no acid and phosphate uncertainty residuals. 
Table 1: Raw Data for Acid $\left(\mathrm{H}_{2} \mathrm{SO}_{4}\right)$ Preservation Comparison Study.

\begin{tabular}{|c|c|c|c|c|}
\hline \multicolumn{5}{|c|}{ Acid versus No Acid Samples in mg/l } \\
\hline $\begin{array}{l}\text { Sample } \\
\text { name }\end{array}$ & $\begin{array}{c}\text { Total } \\
\text { Phosphorus }\end{array}$ & $\begin{array}{c}\text { Total } \\
\text { Phosphorus: } \\
\text { Acid-treated } \\
\text { samples } \\
\end{array}$ & $\begin{array}{c}\text { Total } \\
\text { Nitrogen } \\
\end{array}$ & $\begin{array}{l}\text { Total Nitrogen: } \\
\text { Acid-treated } \\
\text { samples }\end{array}$ \\
\hline P3a_1 & 15.4448 & 15.8388 & 41.4159 & 77.4397 \\
\hline P3a_2 & 17.9374 & 18.2386 & 40.0636 & 102.7436 \\
\hline P3a_3 & 18.0377 & 18.3063 & 39.8947 & 31.2222 \\
\hline $\mathrm{P} 3 \mathrm{a}_{-} 4$ & 16.7652 & 17.6603 & 36.0818 & 99.7675 \\
\hline P3a_5 & 15.9919 & 17.125 & 33.9713 & 75.1275 \\
\hline P3a_6 & 18.2467 & 18.091 & 40.0072 & 79.9955 \\
\hline P3b_1 & 20.8958 & 21.4691 & 42.5714 & 93.068 \\
\hline P3b_2 & 19.6788 & 20.5301 & 41.2512 & 76.0165 \\
\hline P3b_3 & 41.4507 & 19.9384 & 37.5826 & 74.1727 \\
\hline P3b_4 & 18.7097 & 18.8222 & 35.7462 & 87.9968 \\
\hline P3b_5 & 17.4977 & 18.4014 & 34.0578 & 63.8707 \\
\hline P3b_6 & 16.7169 & 17.5807 & 31.965 & 64.5953 \\
\hline P3b_7 & 17.1903 & 17.4992 & 36.9779 & 58.9633 \\
\hline P6a_1 & 18.2476 & 19.9505 & 154.9732 & 333.9521 \\
\hline P6a_2 & 17.3723 & 19.1905 & 138.4805 & 322.0394 \\
\hline P6a_3 & 18.2101 & 19.0719 & 140.8524 & 352.715 \\
\hline P6a_4 & 17.5136 & 19.2264 & 137.7808 & 252.874 \\
\hline P6a_5 & 16.857 & 18.7117 & 130.0648 & 312.6532 \\
\hline P6a_6 & 13.9404 & 18.4942 & 122.7515 & 310.8834 \\
\hline P6a_7 7 & 15.9221 & 17.811 & 119.2545 & 275.3798 \\
\hline P6a_8 & 16.0769 & 17.6102 & 110.9096 & 276.0938 \\
\hline P6a_9 & 16.1048 & 16.9462 & 111.6492 & 265.7439 \\
\hline P6a_10 & 17.9085 & 21.0371 & 174.4509 & 400.608 \\
\hline P6b_1 & 19.5758 & 22.0947 & 135.495 & 329.7355 \\
\hline P6b_2 & 22.0251 & 21.2636 & 125.3582 & 274.3205 \\
\hline P6b_3 & 18.8329 & 20.2434 & 117.0127 & 262.9686 \\
\hline P6b_4 & 17.5758 & 19.9133 & 112.7204 & 274.3419 \\
\hline P6b_5 & 16.9491 & 18.9784 & 105.8142 & 136.9223 \\
\hline P6b_6 & 24.3275 & 18.9872 & 103.0235 & 279.0831 \\
\hline P6b_7 & 17.0288 & 18.1729 & 96.3725 & 280.5063 \\
\hline P6b_8 & 15.8907 & 17.8198 & 90.6192 & 227.0635 \\
\hline P6b_9 & 16.0542 & 17.1161 & 85.5377 & 237.1869 \\
\hline P6b_10 & 15.2682 & 16.2927 & 80.3806 & 108.8166 \\
\hline P6b_11 & 18.5753 & 19.8988 & 125.8473 & 265.6418 \\
\hline
\end{tabular}

Highlighted results are outliers by Chauvent's crition. 
APPENDIX E: Total Carbon Results

Soil Only Trays

\begin{tabular}{|c|c|c|c|c|}
\hline $\begin{array}{l}\text { Sample } \\
\text { Name }\end{array}$ & $\begin{array}{l}\text { Volume } \\
\text { (L) }\end{array}$ & $\begin{array}{c}\mathrm{TC} \\
\text { (Total Carbon) } \\
(\mathrm{mg} / \mathrm{l})\end{array}$ & $\begin{array}{c}\text { IC } \\
\text { (Inorganic } \\
\text { carbon) }(\mathrm{mg} / \mathrm{l})\end{array}$ & $\begin{array}{c}\text { OC } \\
\text { (Organic } \\
\text { carbon) }(\mathrm{mg} / \mathrm{l})\end{array}$ \\
\hline P4a_1 & 1 & 148.20 & 13.36 & 134.90 \\
\hline $\mathrm{P} 4 \mathrm{a} 3$ & 3 & 135.50 & 13.90 & 121.60 \\
\hline P4a 5 & 5 & 128.90 & 14.15 & 114.70 \\
\hline P4a 7 & 7 & 125.70 & 14.42 & 111.30 \\
\hline P4a_9 & 9 & 144.80 & 15.48 & 129.40 \\
\hline P4a_11 & 11 & 167.80 & 17.52 & 150.30 \\
\hline P4b_1 & 1 & 186.50 & 22.14 & 164.40 \\
\hline P4b_3 & 3 & 168.70 & 18.10 & 150.60 \\
\hline P4b_ 4 & 4 & 152.90 & 18.44 & 134.40 \\
\hline P4b 7 & 7 & 136.60 & 15.99 & 120.60 \\
\hline P4b 9 & 9 & 125.00 & 16.95 & 108.00 \\
\hline P4b_11 & 11 & 118.50 & 17.18 & 101.30 \\
\hline P4b_13 & 13 & 143.90 & 18.69 & 125.20 \\
\hline P4b_14 & 14 & 152.60 & 19.48 & 133.10 \\
\hline P5a_1 & 1 & 148.80 & 13.59 & 135.20 \\
\hline P5a_3 & 3 & 141.90 & 14.55 & 127.30 \\
\hline P5a_6 & 6 & 183.50 & 17.39 & 166.10 \\
\hline P5a_7 & 7 & 185.30 & 16.84 & 168.40 \\
\hline P5b 1 & 1 & 189.00 & 21.58 & 167.40 \\
\hline P5b 3 & 3 & 159.30 & 20.01 & 139.30 \\
\hline P5b_5 & 5 & 137.30 & 19.19 & 118.10 \\
\hline P5b_7 & 7 & 209.90 & 21.90 & 188.00 \\
\hline B3a_1 & 1 & 46.81 & 9.92 & 36.89 \\
\hline B3a_3 & 3 & 42.21 & 10.93 & 31.28 \\
\hline B3a 5 & 5 & 66.45 & 15.75 & 50.70 \\
\hline B3b 1 & 1 & 65.67 & 14.51 & 51.16 \\
\hline B3b 3 & 3 & 62.28 & 19.52 & 42.76 \\
\hline B3b 5 & 5 & 57.50 & 18.65 & 38.85 \\
\hline B3b 7 & 7 & 54.34 & 18.16 & 36.18 \\
\hline B3b_9 & 9 & 52.42 & 17.75 & 34.67 \\
\hline B3b_11 & 11 & 55.67 & 17.56 & 38.11 \\
\hline B2a_1 & 1 & 60.30 & 11.22 & 49.08 \\
\hline B2a 3 & 3 & 51.65 & 11.74 & 39.91 \\
\hline B2a 5 & 5 & 46.58 & 12.54 & 34.04 \\
\hline B2a 7 & 7 & 43.10 & 12.40 & 30.70 \\
\hline B2a_9 & 9 & 60.23 & 15.66 & 44.57 \\
\hline B2b 1 & 1 & 66.90 & 20.61 & 46.29 \\
\hline B2b_3 & 3 & 56.18 & 18.89 & 37.29 \\
\hline B2b_5 & 5 & 50.94 & 17.87 & 33.07 \\
\hline B2b_7 & 7 & 47.40 & 17.23 & 30.17 \\
\hline B2b 9 & 9 & 44.54 & 16.81 & 27.73 \\
\hline B2b 11 & 11 & 53.95 & 17.74 & 36.21 \\
\hline
\end{tabular}

Sample name coding: ' $a$ ' is from Run A, ' $b$ ' is from Run B 
Sedum Trays

\begin{tabular}{|c|c|c|c|c|}
\hline $\begin{array}{c}\text { Sample } \\
\text { Name }\end{array}$ & $\begin{array}{l}\text { Volume } \\
\text { (L) }\end{array}$ & $\begin{array}{c}\mathrm{TC} \\
\text { (Total Carbon) } \\
(\mathrm{mg} / \mathrm{l})\end{array}$ & $\begin{array}{c}\text { IC } \\
\text { (Inorganic } \\
\text { carbon) }(\mathrm{mg} / \mathrm{l})\end{array}$ & $\begin{array}{c}\text { OC } \\
\text { (Organic } \\
\text { carbon) }(\mathrm{mg} / \mathrm{l})\end{array}$ \\
\hline P7a_1 & 1 & 91.00 & 9.67 & 81.33 \\
\hline P7a 3 & 3 & 90.84 & 10.71 & 80.13 \\
\hline P7a_5 & 5 & 83.74 & 10.86 & 72.88 \\
\hline P7a 7 & 7 & 80.62 & 10.99 & 69.63 \\
\hline P7a_9 & 9 & 186.40 & 25.33 & 161.07 \\
\hline P7b_1 & 1 & 117.90 & 15.19 & 102.71 \\
\hline P7b 3 & 3 & 109.20 & 14.35 & 94.85 \\
\hline P7b 5 5 & 5 & 95.03 & 13.79 & 81.24 \\
\hline P7b_ 7 & 7 & 92.74 & 13.36 & 79.38 \\
\hline P7b_9 & 9 & 101.70 & 14.23 & 87.47 \\
\hline $\mathrm{P} 2 \mathrm{a}$ & 1 & 103.80 & 9.78 & 94.02 \\
\hline P2a_3 & 3 & 78.43 & 10.06 & 68.37 \\
\hline P2a 5 & 5 & 66.17 & 10.24 & 55.93 \\
\hline P2a_7 & 7 & 60.44 & 10.42 & 50.02 \\
\hline P2a_9 & 9 & 57.65 & 10.53 & 47.12 \\
\hline $\mathrm{P} 2 \mathrm{a} \quad 11$ & 11 & 77.94 & 12.02 & 65.92 \\
\hline P2b_1 & 1 & 115.10 & 19.23 & 95.87 \\
\hline P2b_ 3 & 3 & 78.22 & 14.85 & 63.37 \\
\hline P2b_5 & 5 & 69.04 & 13.04 & 56.00 \\
\hline P2b_ 7 & 7 & 62.28 & 12.61 & 49.67 \\
\hline P2b_9 & 9 & 60.58 & 12.23 & 48.35 \\
\hline P2b 11 & 11 & 61.27 & 11.93 & 49.34 \\
\hline P2b_13 & 13 & 142.40 & 19.89 & 122.51 \\
\hline B6a_1 & 1 & 39.56 & 10.18 & 29.38 \\
\hline B6a 3 & 3 & 38.97 & 11.04 & 27.93 \\
\hline B6a_5 & 5 & 36.96 & 11.19 & 25.77 \\
\hline B6a_7 & 7 & 35.67 & 11.43 & 24.24 \\
\hline B6a_8 & 8 & 39.07 & 12.56 & 26.51 \\
\hline B6b_1 & 1 & 48.77 & 16.24 & 32.53 \\
\hline B6b 3 & 3 & 46.95 & 15.54 & 31.41 \\
\hline B6b 5 & 5 & 42.75 & 15.00 & 27.75 \\
\hline B6b_7 & 7 & 39.71 & 14.54 & 25.17 \\
\hline B6b_9 & 9 & 37.13 & 14.25 & 22.88 \\
\hline B6b 11 & 11 & 39.95 & 14.98 & 24.97 \\
\hline B7a_1 & 1 & 45.27 & 9.69 & 35.58 \\
\hline B7a 3 & 3 & 37.17 & 10.03 & 27.14 \\
\hline B7a_5 & 5 & 33.43 & 10.22 & 23.21 \\
\hline B7a 7 & 7 & 31.41 & 10.43 & 20.98 \\
\hline B7a_8 & 8 & 34.24 & 10.72 & 23.52 \\
\hline B7b 1 & 1 & 47.60 & 16.78 & 30.82 \\
\hline B7b_3 & 3 & 39.08 & 11.76 & 27.32 \\
\hline B7b 5 & 5 & 34.57 & 14.28 & 20.29 \\
\hline B7b 7 & 7 & 32.16 & 13.69 & 18.47 \\
\hline B7b 9 & 9 & 30.18 & 13.53 & 16.65 \\
\hline B7b 10 & 10 & 31.72 & 13.62 & 18.10 \\
\hline B7b 11 & 11 & 40.75 & 15.33 & 25.42 \\
\hline
\end{tabular}

Sample name coding: ' $a$ ' is from Run A, ' $b$ ' is from Run B 
Ryegrass Trays

\begin{tabular}{|c|c|c|c|c|}
\hline $\begin{array}{c}\text { Sample } \\
\text { Name }\end{array}$ & $\begin{array}{c}\text { Volume } \\
\text { (L) }\end{array}$ & $\begin{array}{c}\text { TC } \\
\text { (Total Carbon) } \\
(\mathrm{mg} / \mathrm{l}) \\
\end{array}$ & $\begin{array}{c}\text { IC } \\
\text { (Inorganic } \\
\text { carbon) } \\
(\mathrm{mg} / \mathrm{l}) \\
\end{array}$ & $\begin{array}{c}\text { OC } \\
\text { (Organic } \\
\text { carbon) }(\mathrm{mg} / \mathrm{l})\end{array}$ \\
\hline P3a_1 & 1 & 94.16 & 17.04 & 77.12 \\
\hline P3a_2 & 2 & 107.50 & 18.52 & 88.98 \\
\hline P3a 3 & 3 & 106.90 & 18.70 & 88.20 \\
\hline P3a_4 & 4 & 104.50 & 18.54 & 85.96 \\
\hline P3a_5 & 5 & 99.62 & 18.26 & 81.36 \\
\hline P3a_6 & 6 & 107.00 & 18.83 & 88.17 \\
\hline P3b 1 & 1 & 125.60 & 27.34 & 98.26 \\
\hline P3b_2 & 2 & 119.20 & 25.60 & 93.60 \\
\hline P3b 3 & 3 & 111.00 & 24.15 & 86.85 \\
\hline P3b_ 4 & 4 & 105.80 & 23.11 & 82.69 \\
\hline P3b 5 & 5 & 99.96 & 21.70 & 78.26 \\
\hline P3b_6 & 6 & 96.06 & 22.64 & 73.42 \\
\hline P3b_7 & 7 & 100.80 & 22.02 & 78.78 \\
\hline P6a_1 & 1 & 87.52 & 14.50 & 73.02 \\
\hline P6a_2 & 2 & 84.72 & 14.33 & 70.39 \\
\hline P6a_3 & 3 & 84.82 & 13.97 & 70.85 \\
\hline P6a 4 & 4 & 83.86 & 14.00 & 69.86 \\
\hline P6a_5 & 5 & 78.34 & 14.24 & 64.10 \\
\hline P6a_6 & 6 & 77.03 & 14.29 & 62.74 \\
\hline P6a_7 & 7 & 75.75 & 14.36 & 61.39 \\
\hline P6a_8 & 8 & 71.92 & 14.18 & 57.74 \\
\hline P6a_9 & 9 & 70.53 & 14.18 & 56.35 \\
\hline P6a 10 & 10 & 98.96 & 16.46 & 82.50 \\
\hline P6b_1 & 1 & 97.78 & 22.15 & 75.63 \\
\hline P6b 2 & 2 & 89.89 & 20.05 & 69.84 \\
\hline P6b_3 & 3 & 84.01 & 18.90 & 65.11 \\
\hline P6b 4 & 4 & 62.62 & 12.47 & 50.15 \\
\hline P6b_5 & 5 & 75.85 & 17.48 & 58.37 \\
\hline P6b_6 & 6 & 72.42 & 17.54 & 54.88 \\
\hline P6b 7 & 7 & 70.01 & 17.24 & 52.77 \\
\hline P6b 8 & 8 & 67.54 & 17.02 & 50.52 \\
\hline P6b_9 & 9 & 64.62 & 16.76 & 47.86 \\
\hline P6b_10 & 10 & 62.69 & 16.30 & 46.39 \\
\hline P6b_11 & 11 & 82.91 & 18.54 & 64.37 \\
\hline
\end{tabular}

Sample name coding: ' $a$ ' is from Run A, 'b' is from Run B 
Ryegrass Trays

\begin{tabular}{|c|c|c|c|c|}
\hline $\begin{array}{c}\text { Sample } \\
\text { Name }\end{array}$ & $\begin{array}{c}\text { Volume } \\
\text { (L) }\end{array}$ & $\begin{array}{c}\mathrm{TC} \\
\text { (Total Carbon) } \\
(\mathrm{mg} / \mathrm{l}) \\
\end{array}$ & $\begin{array}{c}\mathrm{IC} \\
\text { (Inorganic } \\
\text { carbon) } \\
(\mathrm{mg} / \mathrm{l}) \\
\end{array}$ & $\begin{array}{c}\text { OC } \\
\text { (Organic } \\
\text { carbon) }(\mathrm{mg} / \mathrm{l})\end{array}$ \\
\hline B4a 1 & 1 & 41.93 & 15.25 & 26.68 \\
\hline B4a_2 & 2 & 41.08 & 15.89 & 25.19 \\
\hline B4a 3 & 3 & 40.01 & 16.15 & 23.86 \\
\hline B4a_4 & 4 & 39.27 & 16.40 & 22.87 \\
\hline B4a_5 & 5 & 37.99 & 15.94 & 22.05 \\
\hline B4a 6 & 6 & 36.85 & 16.02 & 20.83 \\
\hline B4a 7 & 7 & 36.53 & 16.08 & 20.45 \\
\hline B4a_8 & 8 & 35.56 & 16.05 & 19.51 \\
\hline B4a 9 & 9 & 37.74 & 16.50 & 21.24 \\
\hline B4b_1 & 1 & 46.67 & 21.04 & 25.63 \\
\hline B $4 b \_2$ & 2 & 43.82 & 19.87 & 23.95 \\
\hline B4b_3 & 3 & 41.63 & 19.22 & 22.41 \\
\hline B4b_4 & 4 & 40.46 & 19.05 & 21.41 \\
\hline B $4 b \_5$ & 5 & 38.18 & 18.68 & 19.50 \\
\hline B4b_6 & 6 & 36.80 & 18.22 & 18.58 \\
\hline B4b_7 & 7 & 36.02 & 18.80 & 17.22 \\
\hline B4b_ 8 & 8 & 35.22 & 18.19 & 17.03 \\
\hline B4b_9 & 9 & 33.98 & 18.04 & 15.94 \\
\hline B $4 b \_10$ & 10 & 33.21 & 17.93 & 15.28 \\
\hline B4b_11 & 11 & 35.40 & 18.44 & 16.96 \\
\hline B5a_1 & 1 & 33.08 & 12.23 & 20.85 \\
\hline B5a 2 & 2 & 40.34 & 15.28 & 25.06 \\
\hline B5a 3 & 3 & 40.30 & 15.30 & 25.00 \\
\hline B5a_4 & 4 & 38.95 & 15.48 & 23.47 \\
\hline B5a 5 & 5 & 38.01 & 15.45 & 22.56 \\
\hline B5a_6 & 6 & 37.17 & 15.26 & 21.91 \\
\hline B5a 7 & 7 & 36.14 & 15.83 & 20.31 \\
\hline B5a_8 & 8 & 37.47 & 16.06 & 21.41 \\
\hline B5a_9 & 9 & 41.18 & 17.14 & 24.04 \\
\hline B5b_1 & 1 & 47.10 & 20.30 & 26.80 \\
\hline B5b 2 & 2 & 44.95 & 19.80 & 25.15 \\
\hline B5b_3 & 3 & 42.35 & 18.82 & 23.53 \\
\hline B5b_4 & 4 & 40.51 & 18.26 & 22.25 \\
\hline B5b_5 & 5 & 38.65 & 17.96 & 20.69 \\
\hline B5b_6 & 6 & 37.75 & 17.93 & 19.82 \\
\hline B5b_7 & 7 & 36.46 & 17.88 & 18.58 \\
\hline B5b_8 & 8 & 35.60 & 17.72 & 17.88 \\
\hline B5b 9 & 9 & 34.55 & 17.72 & 16.83 \\
\hline B5b_10 & 10 & 34.77 & 17.55 & 17.22 \\
\hline B5b_11 & 11 & 40.52 & 18.43 & 22.09 \\
\hline B5b 12 & 12 & 49.22 & 21.00 & 28.22 \\
\hline
\end{tabular}

Sample name coding: 'a' is from Run A, 'b' is from Run B 
Appendix F: Nitrogen and Phosphorus Sample Results

ProGro trays Soil-only

\begin{tabular}{|c|c|c|c|c|c|c|c|c|c|}
\hline $\begin{array}{c}\text { Sample } \\
\text { Name }\end{array}$ & $\begin{array}{l}\text { Runoff } \\
\text { volume } \\
\text { (Vout) }\end{array}$ & $\begin{array}{l}\text { Vout/ } \\
\text { Vtotal }\end{array}$ & $\begin{array}{l}\text { Nitrate } \\
(\mathrm{mg} / \mathrm{l})\end{array}$ & $\begin{array}{c}\text { Phosphate } \\
(\mathrm{mg} / \mathrm{l})\end{array}$ & $\begin{array}{c}\text { Total } \\
\text { Phosphorus } \\
(\mathrm{mg} / \mathrm{l})\end{array}$ & $\begin{array}{c}\text { Adjusted } \\
\text { Total } \\
\text { Phosphorus } \\
(\mathrm{mg} / \mathrm{l}) \\
\end{array}$ & $\begin{array}{l}\text { Time } \\
(\mathrm{min})\end{array}$ & $\begin{array}{c}\text { Qout } \\
(\mathrm{ml} / \mathrm{min})\end{array}$ & $\begin{array}{c}\text { Qin } \\
(\mathrm{ml} / \mathrm{min})\end{array}$ \\
\hline P4a_1 & 1 & 0.04 & 117.42 & 15.24 & 21.72 & 20.31 & 12.30 & 189.58 & 438.00 \\
\hline $\mathrm{P} 4 \mathrm{a} \_2$ & 2 & 0.08 & 118.02 & 15.60 & 19.64 & 18.46 & 15.50 & 312.50 & 438.00 \\
\hline $\mathrm{P} 4 \mathrm{a} \_3$ & 3 & 0.12 & 115.11 & 15.96 & 19.29 & 18.15 & 18.30 & 357.14 & 438.00 \\
\hline P4a_4 & 4 & 0.16 & 113.78 & 15.43 & 18.83 & 17.74 & 21.27 & 336.70 & 438.00 \\
\hline P4a_5 & 5 & 0.21 & 117.12 & 15.35 & 19.50 & 18.34 & 24.12 & 350.88 & 438.00 \\
\hline P4a_6 & 6 & 0.25 & 128.91 & 15.95 & 20.27 & 19.03 & 26.45 & 429.18 & 438.00 \\
\hline P4a_7 & 7 & 0.29 & 116.80 & 15.87 & 19.06 & 17.95 & 28.90 & 408.16 & 438.00 \\
\hline P4a_8 & 8 & 0.33 & 113.74 & 15.50 & 18.84 & 17.75 & 32.48 & 279.33 & 0.00 \\
\hline P4a_9 & 9 & 0.37 & 126.22 & 16.19 & 21.45 & 20.07 & 34.57 & 478.47 & 0.00 \\
\hline P4a_10 & 10 & 0.42 & 147.15 & 16.55 & 19.38 & 18.23 & 86.00 & 19.44 & 0.00 \\
\hline P4b_1 & 11 & 0.46 & 177.10 & 19.68 & 26.15 & 24.26 & 7.18 & 265.31 & 442.00 \\
\hline P4b 2 & 12 & 0.50 & 167.87 & 19.62 & 25.21 & 23.43 & 9.53 & 425.53 & 442.00 \\
\hline P4b 3 & 13 & 0.54 & 164.18 & 19.70 & 24.06 & 22.40 & 11.75 & 450.45 & 442.00 \\
\hline P4b 4 & 14 & 0.58 & 150.12 & 19.08 & 18.02 & 17.02 & 14.00 & 444.44 & 442.00 \\
\hline P4b 5 & 15 & 0.62 & 149.24 & 18.77 & 23.14 & 21.58 & 16.00 & 500.00 & 442.00 \\
\hline P4b 6 & 16 & 0.67 & 135.53 & 18.39 & 23.12 & 21.56 & 18.13 & 469.48 & 442.00 \\
\hline P4b_ 7 & 17 & 0.71 & 130.91 & 18.15 & 22.11 & 20.67 & 20.25 & 471.70 & 442.00 \\
\hline P4b_ 8 & 18 & 0.75 & 124.12 & 17.73 & 22.49 & 21.01 & 22.37 & 471.70 & 442.00 \\
\hline P4b 9 & 19 & 0.79 & 113.51 & 17.53 & 21.41 & 20.04 & 24.42 & 487.80 & 442.00 \\
\hline $\mathrm{P} 4 \mathrm{~b} \quad 10$ & 20 & 0.83 & 107.43 & 17.12 & 20.04 & 18.82 & 26.63 & 452.49 & 442.00 \\
\hline P4b_11 & 21 & 0.87 & 100.25 & 20.46 & 20.42 & 19.16 & 28.65 & 495.05 & 442.00 \\
\hline P4b_12 & 22 & 0.92 & 97.67 & 16.29 & 19.90 & 18.70 & 30.90 & 444.44 & 0.00 \\
\hline P4b_13 & 23 & 0.96 & 119.84 & 17.85 & 19.17 & 18.05 & 35.45 & 219.78 & 0.00 \\
\hline P4b 14 & 24 & 1.00 & 128.34 & 17.90 & 22.65 & 21.15 & 77.00 & 24.07 & 0.00 \\
\hline
\end{tabular}

\begin{tabular}{|l|r|r|r|r|r|r|r|r|r|}
\hline P5a_1 & 1 & 0.07 & 250.93 & 20.34 & 20.25 & 19.01 & 18.72 & 87.58 & 410.00 \\
\hline P5a_2 & 2 & 0.14 & 240.61 & 23.95 & 25.02 & 23.26 & 23.70 & 200.80 & 410.00 \\
\hline P5a_3 & 3 & 0.21 & 222.52 & 19.45 & 24.28 & 22.60 & 27.80 & 243.90 & 410.00 \\
\hline P5a_4 & 4 & 0.28 & 213.08 & 19.63 & 23.87 & 22.24 & 31.87 & 245.70 & 0.00 \\
\hline P5a 5 & 5 & 0.35 & 222.07 & 20.42 & 23.69 & 22.07 & 36.67 & 208.33 & 0.00 \\
\hline P5a_6 & 6 & 0.43 & 249.23 & 20.89 & 26.10 & 24.22 & 42.17 & 181.82 & 0.00 \\
\hline P5a_7 & 7 & 0.50 & 255.41 & 20.37 & 24.81 & 23.07 & 89.00 & 21.35 & 0.00 \\
\hline P5b_1 & 8 & 0.57 & 273.14 & 24.17 & 29.06 & 26.86 & 13.98 & 96.71 & 414.00 \\
\hline P5b_2 & 9 & 0.64 & 262.11 & 30.86 & 29.94 & 27.65 & 19.37 & 185.53 & 414.00 \\
\hline P5b_3 & 10 & 0.71 & 223.18 & 23.93 & 27.42 & 25.40 & 23.28 & 255.75 & 414.00 \\
\hline P5b_4 & 11 & 0.78 & 208.41 & 22.66 & 26.83 & 24.87 & 27.50 & 236.97 & 414.00 \\
\hline P5b_5 & 12 & 0.86 & 184.97 & 22.60 & 26.40 & 24.49 & 31.28 & 264.55 & 0.00 \\
\hline P5b_6 & 13 & 0.93 & 156.32 & 20.90 & 25.16 & 23.38 & 38.00 & 148.81 & 0.00 \\
\hline P5b_7 & 14 & 1.00 & 238.88 & 23.93 & 38.80 & 35.54 & 53.33 & 65.23 & 0.00 \\
\hline
\end{tabular}

Sample name coding: 'a' : sample is from Run A. 'b' : sample is from Run B 
Biochar trays Soil-only

\begin{tabular}{|c|c|c|c|c|c|c|c|c|c|}
\hline $\begin{array}{c}\text { Sample } \\
\text { Name }\end{array}$ & $\begin{array}{l}\text { Runoff } \\
\text { volume } \\
\text { (Vout) }\end{array}$ & $\begin{array}{l}\text { Vout/ } \\
\text { Vtotal }\end{array}$ & $\begin{array}{l}\text { Nitrate } \\
(\mathrm{mg} / \mathrm{l})\end{array}$ & $\begin{array}{c}\text { Phosphate } \\
(\mathrm{mg} / \mathrm{l})\end{array}$ & $\begin{array}{c}\text { Total } \\
\text { Phosphorus } \\
(\mathrm{mg} / \mathrm{l})\end{array}$ & $\begin{array}{c}\text { Adjusted } \\
\text { Total } \\
\text { Phosphorus } \\
(\mathrm{mg} / \mathrm{l}) \\
\end{array}$ & $\begin{array}{l}\text { Time } \\
(\mathrm{min})\end{array}$ & $\begin{array}{c}\text { Qout } \\
(\mathrm{ml} / \mathrm{min})\end{array}$ & $\begin{array}{c}\text { Qin } \\
(\mathrm{ml} / \mathrm{min}) \\
\end{array}$ \\
\hline B2a 1 & 1 & 0.05 & 37.56 & 10.21 & 12.50 & 12.10 & 12.68 & 128.90 & 414.00 \\
\hline B2a 2 & 2 & 0.10 & 36.94 & 10.72 & 12.69 & 12.27 & 15.93 & 307.69 & 414.00 \\
\hline B2a 3 & 3 & 0.15 & 37.42 & 10.58 & 12.13 & 11.77 & 18.55 & 381.68 & 414.00 \\
\hline B2a 4 & 4 & 0.20 & 35.15 & 10.52 & 14.97 & 14.31 & 21.40 & 350.88 & 414.00 \\
\hline B2a 5 & 5 & 0.25 & 34.50 & 10.18 & 11.69 & 11.38 & 23.98 & 387.60 & 414.00 \\
\hline B2a 6 & 6 & 0.30 & 33.25 & 9.95 & 10.58 & 10.40 & 26.70 & 367.65 & 414.00 \\
\hline B2a 7 & 7 & 0.35 & 31.96 & 9.89 & 11.62 & 11.32 & 29.23 & 395.26 & 414.00 \\
\hline B2a 8 & 8 & 0.40 & 33.61 & 9.80 & 10.94 & 10.71 & 33.22 & 250.63 & 0.00 \\
\hline B2a 9 & 9 & 0.45 & 33.96 & 7.15 & 9.12 & 9.09 & 59.83 & 37.58 & 0.00 \\
\hline B2b_1 & 10 & 0.50 & 49.11 & 13.14 & 16.26 & 15.46 & 7.93 & 172.35 & 414.00 \\
\hline B2b 2 & 11 & 0.55 & 45.04 & 12.92 & 15.57 & 14.84 & 10.80 & 348.43 & 414.00 \\
\hline B2b 3 & 12 & 0.60 & 44.77 & 12.77 & 15.51 & 14.78 & 13.40 & 384.62 & 414.00 \\
\hline B2b 4 & 13 & 0.65 & 42.33 & 13.04 & 15.20 & 14.51 & 16.08 & 373.13 & 414.00 \\
\hline B2b 5 & 14 & 0.70 & 40.65 & 12.34 & 15.14 & 14.46 & 18.53 & 408.16 & 414.00 \\
\hline B2b 6 & 15 & 0.75 & 38.83 & 11.61 & 18.58 & 17.52 & 21.22 & 371.75 & 414.00 \\
\hline B2b 7 & 16 & 0.80 & 38.15 & 11.86 & 13.82 & 13.28 & 23.65 & 411.52 & 414.00 \\
\hline B2b 8 & 17 & 0.85 & 37.51 & 11.76 & 13.80 & 13.26 & 26.28 & 380.23 & 414.00 \\
\hline B2b 9 & 18 & 0.90 & 36.23 & 11.36 & 13.30 & 12.82 & 28.73 & 408.16 & 414.00 \\
\hline B2b 10 & 19 & 0.95 & 34.81 & 11.25 & 13.15 & 12.68 & 31.38 & 377.36 & 0.00 \\
\hline B2b 11 & 20 & 1.00 & 37.19 & 14.35 & 12.56 & 12.16 & 37.12 & 174.22 & 0.00 \\
\hline \multicolumn{10}{|c|}{0.97} \\
\hline B3 a1 & 1 & 0.05 & 20.06 & 8.76 & 9.86 & 9.75 & 14.70 & 82.35 & 442.00 \\
\hline B3 a2 & 2 & 0.12 & 26.68 & 9.62 & 10.83 & 10.61 & 20.55 & 170.94 & 442.00 \\
\hline B3 a3 & 3 & 0.17 & 26.91 & 9.45 & 10.98 & 10.75 & 25.38 & 207.04 & 442.00 \\
\hline B3 a4 & 4 & 0.23 & 26.32 & 9.55 & 10.83 & 10.61 & 30.27 & 204.50 & 442.00 \\
\hline B3 a5 & 5 & 0.29 & 50.55 & 10.73 & 13.33 & 12.84 & 47.20 & 59.07 & 0.00 \\
\hline B3b 1 & 6 & 0.35 & 43.68 & 13.49 & 16.39 & 15.57 & 8.03 & 216.15 & 442.00 \\
\hline B3b 2 & 7 & 0.41 & 41.47 & 13.66 & 16.17 & 15.37 & 10.70 & 374.53 & 442.00 \\
\hline B3b 3 & 8 & 0.47 & 39.57 & 13.08 & 16.16 & 15.36 & 13.07 & 421.94 & 442.00 \\
\hline B3b 4 & 9 & 0.53 & 40.14 & 13.65 & 15.39 & 14.67 & 15.73 & 375.94 & 442.00 \\
\hline B3b 5 & 10 & 0.59 & 39.81 & 12.92 & 15.38 & 14.67 & 17.93 & 454.55 & 442.00 \\
\hline B3b 6 & 11 & 0.65 & 39.20 & 13.10 & 15.79 & 15.04 & 20.42 & 401.61 & 442.00 \\
\hline B3b 7 & 12 & 0.71 & 38.79 & 12.92 & 14.92 & 14.26 & 22.73 & 432.90 & 442.00 \\
\hline B3b 8 & 13 & 0.76 & 37.67 & 12.41 & 14.47 & 13.85 & 25.20 & 404.86 & 442.00 \\
\hline B3b 9 & 14 & 0.82 & 36.82 & 12.58 & 14.01 & 13.45 & 27.48 & 438.60 & 442.00 \\
\hline B $3 b \_10$ & 15 & 0.88 & 35.44 & 12.18 & 13.82 & 13.28 & 29.95 & 404.86 & 442.00 \\
\hline B3b 11 & 16 & 0.94 & 37.53 & 12.91 & 14.49 & 13.88 & 33.30 & 298.51 & 0.00 \\
\hline B3b 12 & 17 & 1.00 & 56.38 & 13.98 & 16.15 & 15.36 & 62.50 & 34.25 & 0.00 \\
\hline
\end{tabular}

Sample name coding: 'a' : sample is from Run A. 'b' : sample is from Run B 
Progro trays Sedum

\begin{tabular}{|c|c|c|c|c|c|c|c|c|c|}
\hline $\begin{array}{c}\text { Sample } \\
\text { Name }\end{array}$ & $\begin{array}{l}\text { Runoff } \\
\text { volume } \\
\text { (Vout) }\end{array}$ & $\begin{array}{l}\text { Vout/ } \\
\text { Vtotal }\end{array}$ & $\begin{array}{l}\text { Nitrate } \\
(\mathrm{mg} / \mathrm{l})\end{array}$ & $\begin{array}{c}\text { Phosphate } \\
(\mathrm{mg} / \mathrm{l})\end{array}$ & $\begin{array}{c}\text { Total } \\
\text { Phosphorus } \\
(\mathrm{mg} / \mathrm{l})\end{array}$ & $\begin{array}{c}\text { Adjusted } \\
\text { Total } \\
\text { Phosphorus } \\
\text { (mg/l) }\end{array}$ & $\begin{array}{l}\text { Time } \\
(\mathrm{min})\end{array}$ & $\begin{array}{c}\text { Qout } \\
\text { (ml/min) }\end{array}$ & $\begin{array}{c}\text { Qin } \\
(\mathrm{ml} / \mathrm{min})\end{array}$ \\
\hline $\mathrm{P} 2 \mathrm{a} \_1$ & 1 & 0.04 & 15.15 & 6.62 & 10.30 & 10.14 & 10.08 & 198.69 & 431.00 \\
\hline P2a 2 & 2 & 0.08 & 13.78 & 6.42 & 9.64 & 9.56 & 13.43 & 298.51 & 431.00 \\
\hline $\mathrm{P} 2 \mathrm{a}$ & 3 & 0.12 & 12.23 & 6.12 & 9.02 & 9.01 & 16.18 & 363.64 & 431.00 \\
\hline $\mathrm{P} 2 \mathrm{a} 4$ & 4 & 0.16 & 11.10 & 5.65 & 8.48 & 8.52 & 19.02 & 352.11 & 431.00 \\
\hline $\mathrm{P} 2 \mathrm{a} \_5$ & 5 & 0.21 & 10.68 & 5.77 & 10.07 & 9.94 & 21.52 & 400.00 & 431.00 \\
\hline P2a_6 & 6 & 0.25 & 10.23 & 5.34 & 7.60 & 7.74 & 24.03 & 398.41 & 431.00 \\
\hline $\mathrm{P} 2 \mathrm{a} 7$ & 7 & 0.29 & 9.91 & 5.60 & 7.53 & 7.68 & 26.35 & 431.03 & 431.00 \\
\hline P2a 8 & 8 & 0.33 & 9.68 & 5.54 & 7.42 & 7.57 & 28.75 & 416.67 & 431.00 \\
\hline P2a_9 & 9 & 0.37 & 9.93 & 5.42 & 7.28 & 7.45 & 32.22 & 288.18 & 0.00 \\
\hline $\mathrm{P} 2 \mathrm{a} \quad 10$ & 10 & 0.42 & 11.81 & 5.67 & 7.63 & 7.76 & 36.03 & 262.47 & 0.00 \\
\hline $\mathrm{P} 2 \mathrm{a} \_11$ & 11 & 0.46 & 17.64 & 6.66 & 9.21 & 9.17 & 41.30 & 189.75 & 0.00 \\
\hline $\mathrm{P} 2 \mathrm{~b} \_1$ & 12 & 0.50 & 20.73 & 9.87 & 13.49 & 12.98 & 7.95 & 161.06 & 450.00 \\
\hline P2b_2 & 13 & 0.54 & 16.02 & 8.22 & 11.23 & 10.97 & 11.65 & 270.27 & 450.00 \\
\hline $\mathrm{P} 2 \mathrm{~b} 3$ & 14 & 0.58 & 13.21 & 7.34 & 10.10 & 9.97 & 14.45 & 357.14 & 450.00 \\
\hline P2b 4 & 15 & 0.62 & 12.46 & 6.87 & 15.31 & 14.60 & 17.13 & 373.13 & 450.00 \\
\hline P2b_5 & 16 & 0.67 & 12.20 & 6.68 & 9.33 & 9.28 & 19.50 & 421.94 & 450.00 \\
\hline P2b 6 & 17 & 0.71 & 11.76 & 6.46 & 8.75 & 8.76 & 21.95 & 408.16 & 450.00 \\
\hline P2b_ 7 & 18 & 0.75 & 11.79 & 6.25 & 8.53 & 8.57 & 24.18 & 448.43 & 450.00 \\
\hline P2b_8 & 19 & 0.79 & 11.64 & 6.11 & 8.39 & 8.44 & 26.62 & 409.84 & 450.00 \\
\hline P2b 9 & 20 & 0.83 & 11.35 & 6.07 & 8.29 & 8.35 & 28.78 & 462.96 & 450.00 \\
\hline P2b_10 & 21 & 0.87 & 11.84 & 6.18 & 8.33 & 8.39 & 31.28 & 400.00 & 0.00 \\
\hline P2b_11 & 22 & 0.92 & 13.09 & 6.37 & 8.74 & 8.75 & 35.05 & 265.25 & 0.00 \\
\hline $\mathrm{P} 2 \mathrm{~b} \quad 12$ & 23 & 0.96 & 18.21 & 7.44 & 10.03 & 9.90 & 40.95 & 169.49 & 0.00 \\
\hline P2b_13 & 24 & 1.00 & 29.19 & 12.62 & 16.79 & 15.92 & 51.97 & 90.74 & 0.00 \\
\hline $\mathrm{P} 7 \mathrm{a} 1$ & 1 & 0.05 & 20.04 & 6.34 & 0.92 & & 12.30 & 133.82 & 405.00 \\
\hline $\mathrm{P} 7 \mathrm{a} \_2$ & 2 & 0.10 & 19.11 & 6.89 & 12.78 & 12.35 & 15.23 & 341.30 & 405.00 \\
\hline $\mathrm{P} 7 \mathrm{a} 3$ & 3 & 0.15 & 17.42 & 6.23 & 9.21 & 9.17 & 17.98 & 363.64 & 405.00 \\
\hline $\mathrm{P} 7 \mathrm{a} \_4$ & 4 & 0.21 & 16.87 & 6.45 & 9.35 & 9.30 & 20.95 & 336.70 & 405.00 \\
\hline P7a_5 & 5 & 0.26 & 16.46 & 6.41 & 9.22 & 9.18 & 23.73 & 359.71 & 405.00 \\
\hline $\mathrm{P} 7 \mathrm{a} 6$ & 6 & 0.31 & 16.34 & 6.09 & 9.00 & 8.98 & 26.77 & 328.95 & 405.00 \\
\hline P7a 7 & 7 & 0.37 & 16.16 & 6.05 & 8.79 & 8.80 & 29.45 & 373.13 & 405.00 \\
\hline P7a_8 & 8 & 0.42 & 19.44 & 7.14 & 10.23 & 10.08 & 35.62 & 162.07 & 0.00 \\
\hline P7a_9 & 9 & 0.47 & 41.77 & 12.37 & 24.48 & 22.78 & 53.35 & 56.40 & 0.00 \\
\hline $\mathrm{P} 7 \mathrm{~b} 1$ & 10 & 0.53 & 28.75 & 9.37 & 12.95 & 12.50 & 8.98 & 144.22 & 420.00 \\
\hline P7b 2 & 11 & 0.58 & 27.14 & 9.24 & 13.40 & 12.90 & 12.32 & 299.40 & 420.00 \\
\hline P7b_3 & 12 & 0.63 & 25.60 & 8.90 & 12.52 & 12.12 & 15.10 & 359.71 & 420.00 \\
\hline P7b 4 & 13 & 0.68 & 24.51 & 8.69 & 12.09 & 11.74 & 18.00 & 344.83 & 420.00 \\
\hline P7b 5 & 14 & 0.74 & 23.20 & 8.65 & 12.04 & 11.69 & 20.72 & 367.65 & 420.00 \\
\hline P7b 6 & 15 & 0.79 & 22.42 & 8.23 & 11.29 & 11.03 & 23.57 & 350.88 & 420.00 \\
\hline P7b 7 & 16 & 0.84 & 21.73 & 8.37 & 11.20 & 10.95 & 26.18 & 383.14 & 420.00 \\
\hline P7b_8 & 17 & 0.89 & 21.31 & 8.31 & 14.26 & 13.67 & 29.13 & 338.98 & 420.00 \\
\hline P7b_9 & 18 & 0.95 & 23.45 & 9.04 & 12.32 & 11.94 & 32.35 & 310.56 & 0.00 \\
\hline $\mathrm{P} 7 \mathrm{~b} \quad 10$ & 19 & 1.00 & 25.53 & 9.51 & 12.66 & 12.24 & 42.57 & 97.85 & 0.00 \\
\hline
\end{tabular}

Sample name coding: 'a' : sample is from Run A. 'b' : sample is from Run B 


\begin{tabular}{|l|r|r|r|r|r|r|r|r|r|}
\hline Biochar trays Sedum & Runoff \\
$\begin{array}{c}\text { Sample } \\
\text { Name }\end{array}$ & $\begin{array}{c}\text { volume } \\
\text { (Vout) }\end{array}$ & $\begin{array}{c}\text { Vout/ } \\
\text { Vtotal }\end{array}$ & $\begin{array}{c}\text { Nitrate } \\
(\mathrm{mg} / \mathrm{l})\end{array}$ & $\begin{array}{c}\text { Phosphate } \\
(\mathrm{mg} / \mathrm{l})\end{array}$ & $\begin{array}{c}\text { Total } \\
\text { Phosphorus } \\
(\mathrm{mg} / \mathrm{l})\end{array}$ & $\begin{array}{c}\text { Adjusted } \\
\text { Total } \\
\text { Phosphorus } \\
(\mathrm{mg} / \mathrm{l})\end{array}$ & $\begin{array}{c}\text { Time } \\
(\mathrm{min})\end{array}$ & $\begin{array}{c}\text { Qout } \\
(\mathrm{ml} / \mathrm{min})\end{array}$ & $\begin{array}{c}\text { Qin } \\
(\mathrm{ml} / \mathrm{min})\end{array}$ \\
\hline B6a_1 & 1 & 0.05 & 30.55 & 6.60 & 10.30 & 10.14 & 14.75 & 94.01 & 439.00 \\
\hline B6a_2 & 2 & 0.10 & 39.20 & 7.67 & 8.52 & 8.55 & 18.07 & 301.20 & 439.00 \\
\hline B6a_3 & 3 & 0.15 & 38.72 & 7.77 & 9.04 & 9.02 & 20.80 & 366.30 & 439.00 \\
\hline B6a 4 & 4 & 0.21 & 36.72 & 7.20 & 8.52 & 8.56 & 23.57 & 361.01 & 439.00 \\
\hline B6a_5 & 5 & 0.26 & 36.01 & 7.30 & 8.63 & 8.66 & 25.92 & 425.53 & 439.00 \\
\hline B6a_6 & 6 & 0.31 & 34.25 & 9.65 & 8.51 & 8.55 & 28.60 & 373.13 & 439.00 \\
\hline B6a_7 & 7 & 0.37 & 37.03 & 7.39 & 8.85 & 8.85 & 31.20 & 384.62 & 0.00 \\
\hline B6a_8 & 8 & 0.42 & 40.35 & 7.51 & 9.28 & 9.24 & 36.17 & 201.21 & 0.00 \\
\hline B6b_1 & 9 & 0.47 & 47.32 & 9.76 & 13.30 & 12.81 & 9.78 & 154.76 & 431.00 \\
\hline B6b_2 & 10 & 0.53 & 52.86 & 10.02 & 11.62 & 11.32 & 12.78 & 333.33 & 431.00 \\
\hline B6b_3 & 11 & 0.58 & 52.68 & 9.79 & 11.88 & 11.55 & 15.07 & 436.68 & 431.00 \\
\hline B6b_4 & 12 & 0.63 & 48.27 & 9.62 & 11.20 & 10.95 & 17.32 & 444.44 & 431.00 \\
\hline B6b_5 & 13 & 0.68 & 46.61 & 9.99 & 11.71 & 11.40 & 19.62 & 434.78 & 431.00 \\
\hline B6b_6 & 14 & 0.74 & 44.14 & 9.31 & 11.24 & 10.98 & 22.13 & 398.41 & 431.00 \\
\hline B6b_7 & 15 & 0.79 & 42.91 & 9.21 & 10.73 & 10.53 & 24.48 & 425.53 & 431.00 \\
\hline B6b_8 & 16 & 0.84 & 41.39 & 9.14 & 10.88 & 10.66 & 27.02 & 393.70 & 431.00 \\
\hline B6b_9 & 17 & 0.89 & 38.24 & 8.89 & 10.52 & 10.34 & 29.28 & 442.48 & 431.00 \\
\hline B6b_10 & 18 & 0.95 & 44.08 & 9.59 & 11.56 & 11.27 & 32.28 & 333.33 & 0.00 \\
\hline B6b_11 & 19 & 1.00 & 44.90 & 9.21 & 10.52 & 10.34 & 37.62 & 187.27 & 0.00 \\
\hline
\end{tabular}

\begin{tabular}{|l|r|r|r|r|r|r|r|r|r|}
\hline B7a_1 & 1 & 0.05 & 5.31 & 5.51 & 6.14 & 6.44 & 15.45 & 147.97 & 412.00 \\
\hline B7a_2 & 2 & 0.10 & 4.20 & 5.24 & 6.18 & 6.47 & 18.20 & 363.64 & 412.00 \\
\hline B7a_3 & 3 & 0.15 & 3.39 & 5.03 & 5.39 & 5.77 & 20.77 & 389.11 & 412.00 \\
\hline B7a_4 & 4 & 0.21 & 2.88 & 5.00 & 5.77 & 6.11 & 23.50 & 366.30 & 412.00 \\
\hline B7a_5 & 5 & 0.26 & 2.11 & 4.57 & 5.23 & 5.62 & 26.00 & 400.00 & 412.00 \\
\hline B7a_6 & 6 & 0.31 & 2.02 & 4.74 & 5.15 & 5.55 & 28.77 & 361.01 & 412.00 \\
\hline B7a_7 & 7 & 0.37 & 2.02 & 4.68 & 4.56 & 5.02 & 31.43 & 375.94 & 0.00 \\
\hline B7a_8 & 8 & 0.42 & 3.31 & 4.51 & 4.97 & 5.39 & 40.80 & 106.72 & 0.00 \\
\hline B7b_1 & 9 & 0.47 & 5.09 & 7.46 & 9.08 & 9.06 & 10.83 & 151.41 & 405.00 \\
\hline B7b_2 & 10 & 0.53 & 4.86 & 9.35 & 7.99 & 8.08 & 13.60 & 361.01 & 405.00 \\
\hline B7b_3 & 11 & 0.58 & 4.45 & 9.25 & 7.73 & 7.85 & 15.80 & 454.55 & 405.00 \\
\hline B7b_4 & 12 & 0.63 & 4.18 & 6.88 & 7.86 & 7.97 & 18.33 & 395.26 & 405.00 \\
\hline B7b_5 & 13 & 0.68 & 3.93 & 6.09 & 6.80 & 7.02 & 20.73 & 416.67 & 405.00 \\
\hline B7b_6 & 14 & 0.74 & 3.70 & 5.90 & 6.86 & 7.08 & 22.13 & 714.29 & 405.00 \\
\hline B7b_7 & 15 & 0.79 & 3.61 & 6.13 & 6.08 & 6.38 & 24.48 & 425.53 & 405.00 \\
\hline B7b_8 & 16 & 0.84 & 3.41 & 8.54 & 5.94 & 6.25 & 27.02 & 393.70 & 405.00 \\
\hline B7b_9 & 17 & 0.89 & 3.54 & 5.93 & 5.99 & 6.30 & 29.28 & 442.48 & 405.00 \\
\hline B7b_10 & 18 & 0.95 & 4.15 & 5.78 & 6.27 & 6.55 & 32.28 & 333.33 & 0.00 \\
\hline B7b_11 & 19 & 1.00 & 8.00 & 5.73 & 6.62 & 6.87 & 37.62 & 187.27 & 0.00 \\
\hline Sample & & & & & &
\end{tabular}

Sample name coding: 'a' : sample is from Run A. 'b' : sample is from Run B 
Progro trays Ryegrass

\begin{tabular}{|c|r|r|r|r|r|r|r|r|r|}
\hline $\begin{array}{c}\text { Sample } \\
\text { Name }\end{array}$ & $\begin{array}{c}\text { Runoff } \\
\text { volume } \\
\text { (Vout) }\end{array}$ & $\begin{array}{c}\text { Vout/ } \\
\text { Vtotal }\end{array}$ & $\begin{array}{c}\text { Nitrate } \\
(\mathrm{mg} / \mathrm{l})\end{array}$ & $\begin{array}{c}\text { Phosphate } \\
(\mathrm{mg} / \mathrm{l})\end{array}$ & $\begin{array}{c}\text { Total } \\
\text { Phosphorus } \\
(\mathrm{mg} / \mathrm{l})\end{array}$ & $\begin{array}{l}\text { Total } \\
\text { Nitrogen } \\
(\mathrm{mg} / \mathrm{l})\end{array}$ & $\begin{array}{c}\text { Time } \\
(\mathrm{min})\end{array}$ & $\begin{array}{c}\text { Qout } \\
(\mathrm{ml} / \mathrm{min})\end{array}$ & $\begin{array}{c}\text { Qin } \\
(\mathrm{ml} / \mathrm{min})\end{array}$ \\
\hline P3a_1 & 1 & 0.08 & 17.20 & 13.19 & 15.44 & 41.42 & 15.50 & 85.29 & 415.00 \\
\hline P3a_2 & 2 & 0.15 & 16.13 & 14.53 & 17.94 & 40.06 & 19.42 & 255.10 & 415.00 \\
\hline P3a_3 & 3 & 0.23 & 14.60 & 14.33 & 18.04 & 39.89 & 23.17 & 266.67 & 415.00 \\
\hline P3a_4 & 4 & 0.31 & 13.53 & 13.92 & 16.77 & 36.08 & 26.65 & 287.36 & 415.00 \\
\hline P3a_5 & 5 & 0.38 & 12.98 & 13.68 & 15.99 & 33.97 & 30.02 & 296.74 & 0.00 \\
\hline P3a_6 & 6 & 0.46 & 15.28 & 13.78 & 18.25 & 40.01 & 34.92 & 204.08 & 0.00 \\
\hline P3b_1 & 7 & 0.54 & 12.84 & 16.24 & 20.90 & 42.57 & 12.63 & 131.31 & 427.00 \\
\hline P3b_2 & 8 & 0.62 & 12.70 & 15.39 & 19.68 & 41.25 & 16.70 & 245.70 & 427.00 \\
\hline P3b_3 & 9 & 0.69 & 11.62 & 14.94 & 41.45 & 37.58 & 20.43 & 268.10 & 427.00 \\
\hline P3b_4 & 10 & 0.77 & 10.41 & 14.51 & 18.71 & 35.75 & 24.00 & 280.11 & 427.00 \\
\hline P3b_5 & 11 & 0.85 & 10.71 & 14.13 & 17.50 & 34.06 & 27.50 & 285.71 & 427.00 \\
\hline P3b_6 & 12 & 0.92 & 10.47 & 13.46 & 16.72 & 31.97 & 30.93 & 291.55 & 0.00 \\
\hline P3b_7 & 13 & 1.00 & 13.79 & 13.28 & 17.19 & 36.98 & 37.12 & 161.55 & 0.00 \\
\hline
\end{tabular}

\begin{tabular}{|l|r|r|r|r|r|r|r|r|r|}
\hline P6a_1 & 1 & 0.05 & 138.68 & 14.77 & 18.25 & 154.97 & 12.50 & 379.17 & 443.00 \\
\hline P6a_2 & 2 & 0.10 & 128.82 & 14.98 & 17.37 & 138.48 & 14.78 & 438.60 & 443.00 \\
\hline P6a_3 & 3 & 0.14 & 128.04 & 14.41 & 18.21 & 140.85 & 16.95 & 460.83 & 443.00 \\
\hline P6a_4 & 4 & 0.19 & 126.28 & 15.06 & 17.51 & 137.78 & 19.25 & 434.78 & 443.00 \\
\hline P6a_5 & 5 & 0.24 & 122.60 & 15.15 & 16.86 & 130.06 & 21.68 & 411.52 & 443.00 \\
\hline P6a_6 & 6 & 0.29 & 116.05 & 14.33 & 13.94 & 122.75 & 23.03 & 740.74 & 443.00 \\
\hline P6a_7 & 7 & 0.33 & 113.20 & 14.07 & 15.92 & 119.25 & 26.37 & 299.40 & 443.00 \\
\hline P6a_8 & 8 & 0.38 & 108.20 & 13.93 & 16.08 & 110.91 & 28.68 & 432.90 & 443.00 \\
\hline P6a_9 & 9 & 0.43 & 103.65 & 13.30 & 16.10 & 111.65 & 31.15 & 404.86 & 0.00 \\
\hline P6a_10 & 10 & 0.48 & 172.46 & 16.30 & 17.91 & 174.45 & 43.52 & 80.84 & 0.00 \\
\hline P6b_1 & 11 & 0.52 & 117.56 & 16.28 & 19.58 & 135.50 & 7.63 & 263.01 & 458.00 \\
\hline P6b_2 & 12 & 0.57 & 115.63 & 16.74 & 22.03 & 125.36 & 10.43 & 357.14 & 458.00 \\
\hline P6b_3 & 13 & 0.62 & 109.38 & 15.81 & 18.83 & 117.01 & 12.98 & 392.16 & 458.00 \\
\hline P6b_4 & 14 & 0.67 & 107.32 & 15.49 & 17.58 & 112.72 & 15.30 & 431.03 & 458.00 \\
\hline P6b_5 & 15 & 0.71 & 99.73 & 14.94 & 16.95 & 105.81 & 17.77 & 404.86 & 458.00 \\
\hline P6b_6 & 16 & 0.76 & 97.88 & 14.90 & 24.33 & 103.02 & 20.27 & 400.00 & 458.00 \\
\hline P6b_7 & 17 & 0.81 & 94.00 & 19.35 & 17.03 & 96.37 & 22.37 & 476.19 & 458.00 \\
\hline P6b 8 & 18 & 0.86 & 89.70 & 14.24 & 15.89 & 90.62 & 25.35 & 335.57 & 458.00 \\
\hline P6b_9 & 19 & 0.90 & 82.58 & 17.32 & 16.05 & 85.54 & 27.83 & 403.23 & 458.00 \\
\hline P6b_10 & 20 & 0.95 & 79.11 & 17.75 & 15.27 & 80.38 & 30.33 & 400.00 & 0.00 \\
\hline P6b_11 & 21 & 1.00 & 117.64 & 16.26 & 18.58 & 125.85 & 36.53 & 161.29 & 0.00 \\
\hline Samp1 & c06 & 19 & 19 & 15 & & & \\
\hline
\end{tabular}

Sample name coding: 'a' : sample is from Run A. 'b' : sample is from Run B 
Biochar trays Ryegrass

\begin{tabular}{|l|r|r|r|r|r|r|r|r|r|}
\hline $\begin{array}{c}\text { Sample } \\
\text { Name }\end{array}$ & $\begin{array}{c}\text { Runoff } \\
\text { volume } \\
\text { (Vout) }\end{array}$ & $\begin{array}{c}\text { Vout/ } \\
\text { Vtotal }\end{array}$ & $\begin{array}{c}\text { Nitrate } \\
(\mathrm{mg} / \mathrm{l})\end{array}$ & $\begin{array}{c}\text { Phosphate } \\
(\mathrm{mg} / \mathrm{l})\end{array}$ & $\begin{array}{c}\text { Total } \\
\text { Phosphate } \\
(\mathrm{mg} / \mathrm{l})\end{array}$ & $\begin{array}{c}\text { Total } \\
\text { Nitrogen } \\
(\mathrm{mg} / \mathrm{l})\end{array}$ & $\begin{array}{c}\text { Time } \\
(\mathrm{min})\end{array}$ & $\begin{array}{c}\text { Qout } \\
(\mathrm{ml} / \mathrm{min})\end{array}$ & $\begin{array}{c}\text { Qin } \\
(\mathrm{ml} / \mathrm{min})\end{array}$ \\
\hline B4a_1 & 1 & 0.05 & 1.14 & 8.30 & \multicolumn{1}{c|}{ invalid } & 10.87 & 13.23 & 243.97 & 439.00 \\
\hline B4a_2 & 2 & 0.10 & 1.20 & 8.02 & 8.34 & 10.71 & 15.78 & 392.16 & 439.00 \\
\hline B4a_3 & 3 & 0.15 & 1.11 & 8.67 & 7.75 & 9.98 & 18.33 & 392.16 & 439.00 \\
\hline B4a_4 & 4 & 0.20 & 0.91 & 7.63 & 8.00 & 9.06 & 20.83 & 400.00 & 439.00 \\
\hline B4a_5 & 5 & 0.25 & 0.85 & 7.90 & 7.72 & 7.96 & 22.67 & 543.48 & 439.00 \\
\hline B4a_6 & 6 & 0.30 & 0.90 & 7.47 & 8.08 & 7.58 & 25.75 & 324.68 & 439.00 \\
\hline B4a_7 & 7 & 0.35 & 0.69 & 7.62 & 7.60 & 8.00 & 28.22 & 404.86 & 439.00 \\
\hline B4a_8 & 8 & 0.40 & 0.70 & 7.59 & 7.39 & 7.07 & 30.68 & 406.50 & 0.00 \\
\hline B4a_9 & 9 & 0.45 & 1.11 & 7.84 & 1.98 & 0.00 & 37.07 & 156.49 & 0.00 \\
\hline B4b_1 & 10 & 0.50 & 0.43 & 10.38 & 9.16 & 11.32 & 8.82 & 187.63 & 458.00 \\
\hline B4b_2 & 11 & 0.55 & 0.60 & 10.10 & 9.64 & 13.43 & 11.38 & 390.63 & 458.00 \\
\hline B4b_3 & 12 & 0.60 & 0.57 & 10.30 & 9.40 & 9.46 & 13.80 & 413.22 & 458.00 \\
\hline B4b_4 & 13 & 0.65 & 0.53 & 10.03 & 9.28 & 8.99 & 16.18 & 420.17 & 458.00 \\
\hline B4b_5 & 14 & 0.70 & 0.43 & 9.23 & 9.20 & 8.03 & 18.58 & 416.67 & 458.00 \\
\hline B4b_6 & 15 & 0.75 & 0.44 & 8.75 & 8.32 & 7.48 & 21.00 & 413.22 & 458.00 \\
\hline B4b_7 & 16 & 0.80 & 0.42 & 10.95 & 8.32 & 6.62 & 23.35 & 425.53 & 458.00 \\
\hline B4b_8 & 17 & 0.85 & 0.45 & 8.51 & 8.09 & 6.67 & 25.72 & 421.94 & 458.00 \\
\hline B4b_9 & 18 & 0.90 & 0.36 & 8.43 & 8.08 & 6.31 & 28.08 & 423.73 & 458.00 \\
\hline B4b_10 & 19 & 0.95 & 0.43 & 8.14 & 10.52 & 0.00 & 30.47 & 418.41 & 0.00 \\
\hline B4b_11 & 20 & 1.00 & 0.47 & 8.99 & 8.30 & 6.98 & 35.10 & 215.98 & 0.00 \\
\hline
\end{tabular}

\begin{tabular}{|l|r|r|r|r|r|r|r|r|r|}
\hline B5a_1 & 1 & 0.05 & 4.47 & 9.15 & 8.72 & 14.69 & 13.82 & 129.08 & 412.00 \\
\hline B5a_2 & 2 & 0.10 & 4.12 & 9.02 & 8.58 & 14.42 & 16.50 & 373.13 & 412.00 \\
\hline B5a_3 & 3 & 0.14 & 4.08 & 9.52 & 9.05 & 13.65 & 19.10 & 384.62 & 412.00 \\
\hline B5a_4 & 4 & 0.19 & 3.86 & 9.10 & 9.17 & 12.24 & 21.68 & 387.60 & 412.00 \\
\hline B5a_5 & 5 & 0.24 & 3.45 & 9.32 & 8.95 & 11.81 & 24.23 & 392.16 & 412.00 \\
\hline B5a_6 & 6 & 0.29 & 3.21 & 10.95 & 8.87 & 11.14 & 26.67 & 409.84 & 412.00 \\
\hline B5a_7 & 7 & 0.33 & 3.05 & 9.07 & 8.46 & 10.85 & 29.15 & 403.23 & 412.00 \\
\hline B5a_8 & 8 & 0.38 & 3.17 & 9.75 & 8.71 & 11.62 & 32.08 & 341.30 & 0.00 \\
\hline B5a_9 & 9 & 0.43 & 4.06 & 10.97 & 2.94 & -3.12 & 44.38 & 81.30 & 0.00 \\
\hline B5b_1 & 10 & 0.48 & 3.06 & 11.66 & 11.21 & 13.60 & 8.98 & 143.08 & 427.00 \\
\hline B5b_2 & 11 & 0.52 & 3.23 & 12.09 & 12.19 & 13.58 & 11.60 & 381.68 & 427.00 \\
\hline B5b_3 & 12 & 0.57 & 2.96 & 10.91 & 10.05 & 12.83 & 14.05 & 408.16 & 427.00 \\
\hline B5b_4 & 13 & 0.62 & 2.85 & 9.99 & 9.91 & 11.59 & 16.43 & 420.17 & 427.00 \\
\hline B5b_5 & 14 & 0.67 & 2.63 & 9.70 & 9.12 & 10.31 & 18.83 & 416.67 & 427.00 \\
\hline B5b_6 & 15 & 0.71 & 2.52 & 9.46 & 9.65 & 9.34 & 21.25 & 413.22 & 427.00 \\
\hline B5b_7 & 16 & 0.76 & 2.41 & 9.46 & 8.81 & 9.12 & 23.65 & 416.67 & 427.00 \\
\hline B5b_8 & 17 & 0.81 & 2.28 & 8.83 & 8.69 & 8.31 & 26.03 & 420.17 & 427.00 \\
\hline B5b_9 & 18 & 0.86 & 2.18 & 8.57 & 8.27 & 7.86 & 28.42 & 418.41 & 427.00 \\
\hline B5b_10 & 19 & 0.90 & 2.25 & 8.74 & 8.68 & 7.75 & 30.50 & 480.77 & 0.00 \\
\hline B5b_11 & 20 & 0.95 & 3.00 & 9.61 & 10.28 & 9.13 & 36.93 & 155.52 & 0.00 \\
\hline B5b_12 & 21 & 1.00 & 4.26 & 11.12 & 12.44 & 13.19 & 67.30 & 32.93 & 0.00 \\
\hline Samp1e & cod & & & & & & \\
\hline
\end{tabular}

Sample name coding: 'a' : sample is from Run A. 'b' : sample is from Run B 